\title{
FATORES QUE DETERMINAM A PRODUÇÃO DE IL-12 EM MACRÓFAGOS MURINOS ATIVADOS POR
}

Bordetella pertussis e B. parapertussis

\author{
Dissertação apresentada ao \\ Programa de Pós-Graduação \\ Interunidades em Biotecnologia \\ USP/Instituto Butantan/IPT, para \\ obtenção do Título de Mestre em \\ Biotecnologia.
}




\section{CYNTHIA SOARES GALHARDO}

\section{FATORES QUE DETERMINAM A PRODUÇÃO DE IL-12 EM MACRÓFAGOS MURINOS ATIVADOS POR \\ Bordetella pertussis e B. parapertussis}

Dissertação apresentada ao Programa de Pós-Graduação Interunidades em Biotecnologia USP/ Instituto Butantan/IPT, para obtenção do Título de Mestre em Biotecnologia.

Área de concentração: Biotecnologia

Orientadora: Dra. Monamaris Marques Borges

Versão corrigida. A versão original eletrônica encontra-se disponível tanto na Biblioteca do ICB quanto na Biblioteca Digital de Teses e Dissertações da USP (BDTD). 
DADOS DE CATALOGAÇÃO NA PUBLICAÇÃO (CIP)

Serviço de Biblioteca e Informação Biomédica do

Instituto de Ciências Biomédicas da Universidade de São Paulo

reprodução não autorizada pelo autor

Galhardo, Cynthia Soares.

Fatores que determinam a produção de IL-12 em macrófagos murinos ativados por Bordetella pertussis e B. parapertussis / Cynthia Soares Galhardo. -- São Paulo, 2013.

Orientador: Profa. Dra. Monamaris Marques Borges.

Dissertação (Mestrado) - Universidade de São Paulo. Instituto de Ciências Biomédicas. Programa de Pós-Graduação Interunidades em Biotecnologia USP/IPT/Instituto Butantan. Área de concentração: Biotecnologia. Linha de pesquisa: Imunidade em infecção por Bordetella pertussis e B. parapertussis.

Versão do título para o inglês: Factors determining the production of IL-12 in murine macrophages activated by Bordetella pertussis and $B$. parapertussis.

$\begin{array}{llll}\text { 1. Macrófagos } & \text { 2. Coqueluche } & 3 \text {. Bordetella } \quad 4 \text {. Interleucina } 12\end{array}$ 5. Receptores toll-like 6. Vias de sinalização I. Borges, Profa. Dra. Monamaris Marques II. Universidade de São Paulo. Instituto de Ciências Biomédicas. Programa de Pós-Graduação Interunidades em Biotecnologia USP/IPT/Instituto Butantan III. Título. 
Candidato(a): $\quad$ Cynthia Soares Galhardo.

Título da Fatores que determinam a produção de IL-12 em macrófagos murinos ativados por Bordetella pertussis e $B$. parapertussis.

Orientador(a): $\quad$ Profa. Dra. Monamaris Marques Borges.

A Comissão Julgadora dos trabalhos de Defesa da Dissertação de Mestrado, em sessão pública realizada a considerou
( ) Aprovado(a)
( ) Reprovado(a)

Examinador(a): Assinatura:

Nome:

Instituição:

Examinador(a): Assinatura:

Nome:

Instituição:

Presidente: Assinatura:

Nome:

Instituição: 


\section{CERTIFICADO}

Certificamos que o projeto intitulado "Modulação da síntese de IL-12 por citocinas pró e antiinflamatórias durante a ativação de macrófagos por Bordetella pertussis e B. parapertussis", protocolo $\mathrm{n}^{0}$ 535/08, sob a responsabilidade de Monamaris Marques Borges e Cynthia Soares Galhardo - que envolve a criação e/ou utilização de animais pertencentes ao filo Chordata, subfilo Vertebrata (exceto o homem), para fins de pesquisa científica - está de acordo com os preceitos da Lei n ${ }^{\circ} 11.794$, de 8 de outubro de 2008, do Decreto 6.899, de 15 de julho de 2009 e de normas complementares, bem como está de acordo com os Princípios Éticos na Experimentação Animal adotado pelo Colégio Brasileiro de Experimentação Animal (COBEA), e foi aprovado pela COMISSÃO DE ÉTICA NO USO DE ANIMAIS DO INSTITUTO BUTANTAN (CEUAIB) em reunião de 20/02/2013.

\begin{tabular}{|c|c|c|}
\hline $\begin{array}{c}\text { Vigência do Projeto: } \\
02 / 2009-02 / 2014\end{array}$ & $\mathbf{N}^{\circ}$ de animais/espécie & Aditivo/Observação \\
\hline Laboratório de Bacteriologia & 15 camundongos C57BL/6 Knockout - & Alteração de vigência \\
& Inclusão de espécie \\
15 camundongos C57BL/6 (F); & \\
15 camundongos C3H/HeJ (F) & \\
\cline { 2 - 3 } & &
\end{tabular}

São Paulo, 5 de março de 2013

Dra. Wafa H. K. Cabrera Vice-Coordenadora da CEUAIB 


\section{AGRADECIMENTOS}

A Deus, por guiar meu caminho, pela minha família e pelos meus amigos.

Aos meus pais, Clair e Marco, pelo carinho, por sempre estarem ao meu lado, me ajudando no que for preciso. Amo vocês!

À minha irmã, Maitê, pela amizade e compreensão.

Ao Rafa, meu namorado, por me escutar pacientemente todo dia, pela compreensão, pelo apoio nos estudos, por sempre estar ao meu lado me incentivando.

À minha orientadora, Monamaris, por me dar a oportunidade de estar no laboratório, pela paciência e pelos ensinamentos.

À Andreza, por ter me acolhido, pela paciência de me ensinar os protocolos do laboratório, pelas conversas, por toda ajuda e principalmente pela amizade.

À Pri Iamashita, pelo apoio, pela força, pelos vários momentos inesquecíveis de riso e pela amizade.

Ao Diego (meu "Pai") que se tornou um grande amigo, pelas longas conversas, por compartilhar os momentos de alegria e angústias, por dividir a responsabilidade do laboratório comigo, por estar do meu lado sempre me ajudando, pela confiança, pelos conselhos.

À Gabi, uma pessoa especial, que se tornou minha amiga, sempre disposta a ajudar, pelo apoio, confiança, preocupação e pelas inúmeras conversas.

À Marina que foi me conquistando aos poucos até se tornar minha amiga, pelas conversas matinais, pelos desabafos, pela ajuda, pela confiança e pelas risadas.

À Keyde pela amizade, troca de conhecimentos, ajuda, risadas e conversas com uns puxões de orelha sinceros de vez em quando, os quais a gente não esquece. 
À Chris Ozaki pela ajuda, conversas e amizade.

À Gleice ("Freirinha") que com seu jeito discreto do interior foi conquistando minha amizade, por compartilhar momentos de alegria e tristeza, pelo incentivo.

Ao Rafael Nassar pelas conversas e discussão de resultados, apoio, força, incentivo, confiança e ajuda.

Ao Márcio e ao Renato por sempre estarem dispostos a ajudar e pelos momentos de descontração.

Ao Lucas, Bruna, Natália, Raphael, Dani Mourão, Caio, Bruno, Andressa e o Roberto pelas conversas e ajuda.

Às minhas amigas, Dri, Cris, Pri Bruce, Karen, pelo apoio e incentivo, por acreditarem no meu potencial, pela confiança, paciência e pelas conversas. Amizade eterna.

À minha sogra, Ermelinda, pela preocupação e pelo chá de camomila para me acalmar.

Á Thaís Alves, pelas conversas, risadas, incentivo, troca de experiências, ajuda e por compartilhar momentos de angústia.

Ao Luiz e à Laura, por acreditar em mim pessoalmente e profissionalmente, pelas conversas, conselhos e incentivo.

As minhas mais novas companheiras de laboratório, Priscila Zorzetto e Thyátira, por me ajudarem nos momentos de desespero, por acreditarem em mim, pelas conversas e pela força.

Ao Edson, por cuidar dos camundongos e ajudar com toda sua boa vontade sempre que preciso. 
Aos pesquisadores do laboratório de Bacteriologia do Instituto Butantan, em especial a Dra. Denise Horton, pelas palavras de conforto nos momentos de desespero, pelos elogios, pelo incentivo, pela colaboração e disposição a ajudar.

Aos funcionários e alunos do laboratório de Bacteriologia do Instituto Butantan, pelo auxílio na preparação dos materiais e soluções a serem usados nos experimentos e pela utilização dos equipamentos.

Ás professoras Milene Tino de Franco, Eliana Faquim e Patrícia Clissa, pela conversa e sugestões feitas no meu exame de qualificação contribuindo assim para melhorar o trabalho.

Ao setor de Meios de Cultura do Instituto Butantan, por prepararem as placas de meio Bordet-Gengou com sangue para o cultivo de Bordetella.

Ao Jorge do laboratório de Imunoquímica do Instituto Butantan pelas leituras de FACS.

Á Márcia e a Talita do Serviço de Controle de Qualidade de Instituto Butantan, pela dosagem de endotoxina presente nos antígenos solúveis bacterianos utilizados. E ao Marco Aurélio Piantola do laboratório de Bacteriologia, pelo incentivo para ser realizada essa dosagem e pelo esclarecimento de dúvidas em relação ao teste LAL.

À CAPES, pelo apoio financeiro.

Enfim, a todos que de alguma maneira contribuíram para a realização desse trabalho. Muito obrigada! 
"Agradeço todas as dificuldades que enfrentei; não fosse por elas, eu não teria saído do lugar. As facilidades nos impedem de caminhar. Mesmo as críticas nos auxiliam muito.” 


\section{RESUMO}

GALHARDO, C. S. Fatores que determinam a produção de IL-12 em macrófagos murinos ativados por Bordetella pertussis e B. parapertussis. 2013. 96 f. Dissertação (Mestrado em Biotecnologia) - Instituto de Ciências Biomédicas, Universidade de São Paulo, São Paulo, 2013.

A coqueluche é uma doença respiratória muito severa em crianças sendo reemergente em países com alta cobertura vacinal, o que lhe atribui alta relevância em saúde pública. Sua reemergência foi atribuída a alguns fatores dentre eles a adaptação do patógeno ao hospedeiro, possibilitando a regulação de fatores de virulência e sua sobrevivência. A Bordetella pertussis e B. parapertussis são os agentes etiológicos da coqueluche. Estas bactérias diferem na estrutura da molécula de LPS e na expressão da toxina pertussis, o que pode refletir na capacidade de infectar o hospedeiro e na resposta imune induzida. A infecção com B. pertussis induz a resposta Th1, crucial no controle de infecções. A IL-12 é sintetizada principalmente por macrófagos e células dendríticas e induz a produção de IFN- $\gamma$ por células Natural killer (NK), linfócitos $\mathrm{TCD}^{+}$e $\mathrm{TCD}^{+}$, promovendo a diferenciação de $\mathrm{Th} 1$ e a produção de anticorpos que tem papel na resolução da infecção, além de favorecer a eficácia de vacinas. Os macrófagos possuem receptores Toll-like que reconhecem moléculas padrões associados a patógenos, iniciando a resposta inflamatória devido à produção de quimiocinas, citocinas e outros mediadores imunes importantes para a proteção do hospedeiro. Pouco se conhece sobre os mecanismos de controle da síntese de IL-12 em infecções com B. pertussis e $B$. parapertussis, além disto, as vacinas pertussis comerciais disponíveis são ineficientes contra $B$. parapertussis. Neste trabalho investigamos alguns mecanismos de resposta inata que controlam a síntese de IL-12 em macrófagos derivados de medula óssea murina (M $\phi D M)$ ativados in vitro com B. pertussis e $B$. parapertussis. Essas informações podem auxiliar na definição de sinais moleculares que possam ser alvo de drogas ou auxiliar no desenvolvimento de vacinas. Nossos resultados mostraram que IL-12p40 e TNF- $\alpha$ foram produzidos pelos $\mathrm{M} \phi \mathrm{DM}$ ativados com as duas espécies de bactérias, não havendo diferença significativa entre elas quanto à síntese de IL-12p40, porém a infecção ativa com $B$. parapertussis induziu níveis superiores de TNF- $\alpha$ em relação a $B$. pertussis. Na ativação com qualquer uma das bactérias, a síntese de IL-12p40 foi dependente de TNF- $\alpha$, MyD88 e NFкB e independente de MAPK p38 e ERK 1/2. No entanto, a produção desta citocina foi dependente de TLR-4 durante a ativação com $B$. pertussis, mas envolveu outras vias independentes de MyD88 e TLR-4 na ativação com B. parapertussis. Apesar da complexidade antigênica destas duas bactérias, a ativação de $\mathrm{M} \phi \mathrm{DM}$ com qualquer uma delas não induziu a síntese de IL-12p70, necessitando de sinais moleculares adicionais provenientes de IFN- $\gamma$ que favoreceu a síntese desta citocina em resposta a estimulação com estas bactérias. Além disto, a produção de IL-12p70 foi favorecida igualmente pelo bloqueio da via PI3K, MAPK p38 e ERK1/2 e pela adição exógena de PT (inibidor de proteína Gai) durante a ativação com $B$. parapertussis, comprovando que estas vias de sinalização regulam a produção desta citocina. Portanto, nossos dados mostram que a síntese de IL-12 pelos M $\phi D M$ ativados por $B$. pertussis e $B$. parapertussis é controlada por diversas vias de sinalização dependentes e independentes de TLR-4 neste modelo.

Palavras-chave: Bordetella sp. Coqueluche. Macrófagos. IL-12. Receptores Toll-like. Vias de sinalização. 


\begin{abstract}
GALHARDO, C. S. Factors determining the production of IL-12 in murine macrophages activated by Bordetella pertussis and B. parapertussis. 2013. 96 p. Masters thesis (Biotechnology) - Instituto de Ciências Biomédicas, Universidade de São Paulo, São Paulo, 2013.
\end{abstract}

Whooping cough is a severe respiratory disease affecting mainly children around the world. It is reemerging in countries with a high vaccination coverage, which makes it a relevant threat for public health. Its reemergence has been attributed to factors such as the adaptation of the pathogen to the host, enabling the regulation of virulence factors and the survival of the pathogen. Bordetella pertussis and B. parapertussis are the etiologic agents of the disease and they differ from each other on the LPS molecule structure and on the expression of the pertussis toxin, which may affect the infecting capacity and the induction of the immune response. B. pertussis induces the expression of Th1, which is crucial in infection control. IL12 is mainly synthesized by macrophages and dendritic cells and induces the production of IFN- $\gamma$ by natural killer cells and $\mathrm{TCD} 4^{+}$and $\mathrm{TCD} 8^{+}$lymphocytes, which then induces Th1 differentiation and the production of antibodies, which play a role in infection resolution and improve the efficacy of vaccines. Macrophages possess Toll-like receptors which recognize pathogen associated molecular patterns, triggering the inflammatory response through the release of chemokines, cytokines and other immune mediators important for host protection. Little is known on the mechanisms controlling IL-12 synthesis in B. pertussis and $B$. parapertussis infections. In addition, commercially available pertussis vaccines are inefficient against $B$. parapertussis. In this work we have investigated some of the innate response mechanisms involved in the control of the synthesis of IL-12 by murine bone marrow derived macrophages $(\mathrm{M} \phi \mathrm{DM})$ activated in vitro with B. pertussis and B. parapertussis. This knowledge may help define the molecular signals that could be targets for drugs or be used in the development of vaccines. Our results showed that IL-12p40 and TNF- $\alpha$ are produced by M $\phi D M$ activated by either bacterial species, with no significant differences between them. On the hand, active $B$. parapertussis infection induced higher levels of TNF- $\alpha$ in comparison with $B$. pertussis. Upon activation with any of the bacteria, synthesis of IL-12p40 depended on TNF- $\alpha$, MyD88 and NFאB, but did not depend on MAPK p38 and ERK 1/2. However, production of this cytokine was dependent on TLR-4 during activation with $B$. pertussis, although it involved additional MyD88 and TLR-4 independent pathways upon activation with $B$. parapertussis. In spite of their antigenic complexity, M $\phi D M$ activation with either one of these bacteria did not induce IL-12p70 synthesis, requiring additional molecular signals such as IFN- $\gamma$, which did induce IL-12p70 synthesis in response to stimulation with these pathogens. Furthermore, blocking the PI3K, MAPK p38 and ERK1/2 pathways and the addition of exogenous PT (an inhibitor of the Gai protein) also contributed to induce IL12 p70 production during activation with $B$. parapertussis, confirming that these signaling pathways control the production of this cytokine. Thus, our results show that IL-12 synthesis by $\mathrm{M} \phi \mathrm{DM}$ activated with either $B$. pertussis or $B$. parapertussis is controlled through a number of both TLR-4 dependent and independent signaling pathways.

Keywords: Bordetella sp. Whooping cough. Macrophages. IL-12. Toll-Like Receptors. Signaling pathways. 


\section{LISTA DE ILUSTRAÇÕES}

Figura 1 - Estrutura do lipídio A de quatro espécies do gênero Bordetella, destacando o número e distribuição das cadeias de ácidos graxos.

Figura 2 - Representação esquemática do sistema de dois componentes BvgA/S de Bordetella.

Figura 3 - PAMPs reconhecidos pelos diferentes TLRs e suas moléculas adaptadoras...29

Figura 4 - Vias de sinalização mediadas por TLR-4 e TLR-3. .31

Figura 5 - Análise por FACS da expressão da molécula F4/80 na superfície de M $\phi D M$ diferenciados in vitro

Figura 6 - Comparação entre $B$. pertussis e B. parapertussis quanto à capacidade de ativar M $\phi D M$ a sintetizar IL-12p40.

Figura 7 - Produção de TNF- $\alpha$ por M $\phi D M$ de camundongos C57BL/6 ativados in vitro por B. pertussis e B. parapertussis

Figura 8 - Regulação da síntese de IL-12p40 por TNF- $\alpha$ em M $\phi D M$ estimulados com antígeno solúvel de $B$. pertussis e $B$. parapertussis.

Figura 9 - Participação de MyD88 na regulação da síntese de IL-12p40 por M $\phi D M$ estimulados com antígeno de $B$. pertussis e $B$. parapertussis.

Figura 10 - Efeito da inibição de NFkB na regulação da síntese de IL-12p40 por M $\phi D M$ estimulados com antígeno de $B$. pertussis e $B$. parapertussis .55

Figura 11 - Participação do receptor TLR-4 na indução da síntese de IL-12p40 após ativação de $M \phi D M$ com antígeno solúvel ou infectados ativamente com $B$. pertussis......56

Figura 12 - Participação do receptor TLR-4 na indução da síntese de IL-12p40 após infecção de $\mathrm{M} \phi \mathrm{DM}$ com $B$. parapertussis.

Figura 13 - Produção de IL-12p70 após ativação de $M \phi D M$ com $B$. pertussis e $B$. parapertussis.

Figura 14 - Efeito do IFN- $\gamma$ sobre a síntese de IL-12p70 por $M \phi D M$ estimulados com antígeno de $B$. pertussis e $B$. parapertussis.

Figura 15 - Participação de p38 e Erk MAPkinases na regulação da síntese de IL-12p40 em M $\phi D M$ estimulados com antígeno solúvel de $B$. pertussis ou $B$. parapertussis.

Figura 16 - Participação de p38 e Erk MAPkinases na regulação da síntese de IL-12p70 em M $\phi D M$ estimulados com antígeno solúvel de $B$. pertussis ou $B$. parapertussis 
Figura 17 - Regulação da síntese de IL-12p70 por PI3K em M $\phi D M$ estimulados com antígeno solúvel de $B$. pertussis e $B$. parapertussis.....

Figura 18 - Análise da síntese de IL-12p70 em M $\phi D M$ tratados com PT e estimulados com antígeno solúvel de $B$. parapertussis. .68 


\section{LISTA DE ABREVIATURAS E SIGLAS}

ACT ou CyaA - Toxina adenilato ciclase

Ag - Antígeno

AMPc - Adenosina monofosfato cíclico

AP-1 - ativador proteico 1

APC - Célula apresentadora de antígeno

ATP - Adenosina trifosfato

$\mathrm{BG}$ - meio de cultura Bordet-Gengou

CLRs - receptores de lectina tipo C

DCs - Células dendríticas

DNA - Ácido desoxirribonucleico

DNT - Toxina dermonecrótica

DTP - Vacina tríplice contra difteria, tétano e coqueluche (pertussis)

EBI 3 - Gene 3 induzido pelo vírus Epstein-Barr

ELISA - enzyme-linked immunosorbent assay

FACS - Separação de células ativadas por fluorescência

FcR - Receptores para Fc de imunoglobulinas

FHA - Hemaglutinina filamentosa

Gai - Proteína G inibitória

IFN- $\gamma-$ Interferon gama

Ig - Imunoglobulina

IL- Interleucina

iNOS - Óxido nítrico sintase induzida

IRAKs - Proteínas quinases associadas ao receptor da IL-1

IRF - Fator regulador de interferon 
LAL - Limulus Amebocyte Lysate

LPS - Lipopolissacarídeo

LTA - Ácido lipoteicóico

MAPKs - Proteínas quinases ativadas por mitógenos

M-CSF - Fator estimulador de colônias de macrófagos

MDDC - Células dendríticas derivadas de monócitos humanos

M $\phi \mathrm{DM}$ - Macrófagos derivados de medula óssea murina

MHC - Complexo principal de histocompatibilidade

MIP-2 - Proteína inflamatória de macrófagos 2

MyD88 - Proteína de diferenciação mielóide 88

$\mathrm{NF \kappa B}$ - Fator de transcrição nuclear kappa B

NK - Células Natural Killer

NLRs - Receptores NOD-like

OMS - Organização Mundial da Saúde

PAMPs - Padrões moleculares associados a patógenos

PCR - Reação em cadeia da polimerase

PI3K - Fosfatidilinositol 3 quinase

PRN - Pertactina

PRRs - Receptores de reconhecimento padrão

PT - Toxina pertussis

PTB - Subunidade B da toxina pertussis

RIP1 - Proteína 1 de interação com o receptor

RLRs - Receptores de gene 1 induzido por ácido retinóico, RIG-1-like

RNA - Ácido Ribonucleico

SINAN - Sistema de informação de Agravos de Notificação

SDS - Dodecil-sulfato de sódio 
TCT - Citotoxina traqueal

TGF- $\beta$ - Fator de transformação de crescimento beta

Th - Linfócito T helper (auxiliar)

TLRs - Receptores Toll-like

TNF- $\alpha$ - Fator de necrose tumoral alfa

TNFR1 - Receptor 1 do TNF

TRAF-3 - Fator 3 associado ao receptor de TNF

TRAF-6 - Fator 6 associado ao receptor de TNF

T reg - Linfócitos T regulatórios

TTSS - Sistema de secreção 


\section{SUMÁRIO}

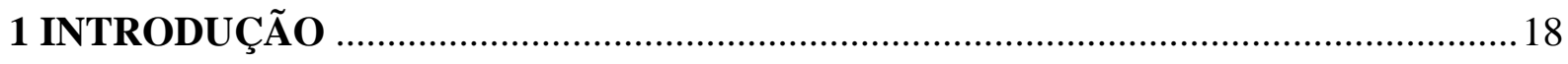

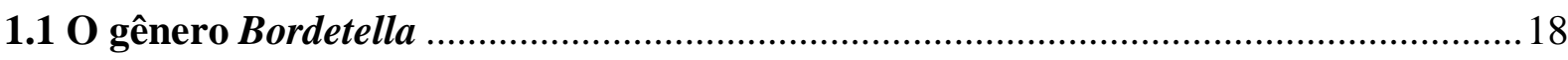

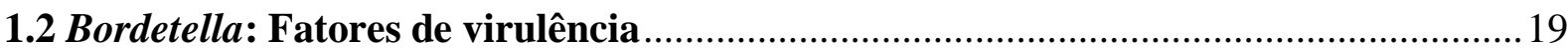

1.3 Aspectos epidemiológicos e controle da infecção por Bordetella .................................23

1.4 O papel dos macrófagos na imunidade inata e a síntese de IL-12 ...........................27

1.4.1 Os receptores Toll-like na ativação da imunidade inata ............................................28

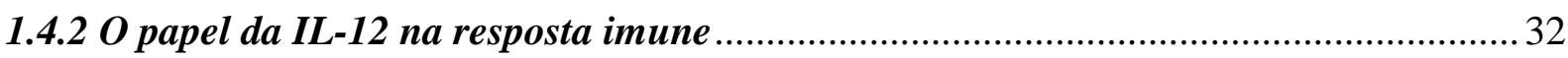

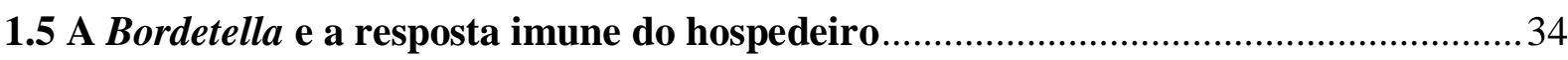

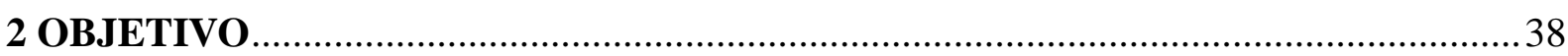

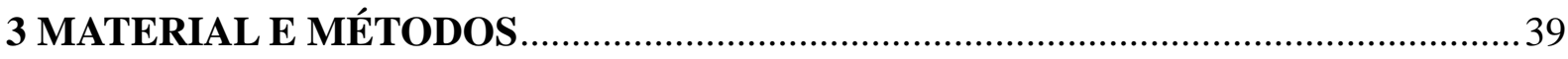

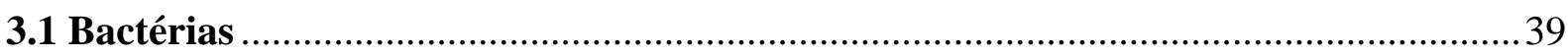

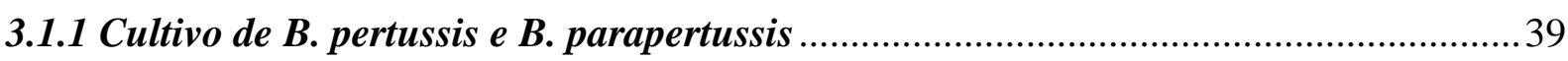

3.1.2 Obtenção dos componentes solúveis (antígeno solúvel) de B. pertussis ou B.

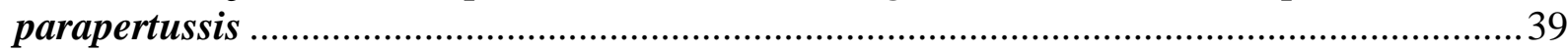

3.1.3 Dosagem de endotoxina do antígeno solúvel de B. pertussis ou B. parapertussis ....... 40

3.1.4 Obtenção de bactérias viáveis para infecção in vitro ...............................................4 40

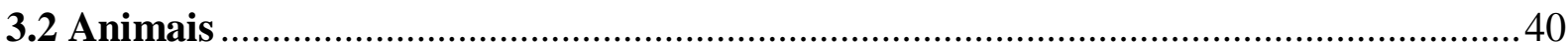

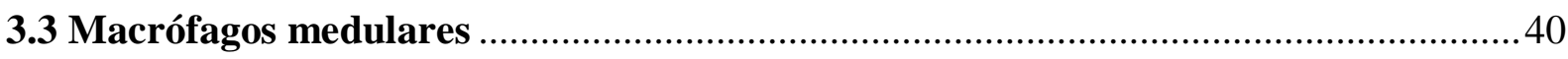

3.3.1 Cultivo de células L929 para obtenção do fator de crescimento M-CSF .................... 41

3.3.2 Obtenção e cultivo de macrófagos derivados de medula óssea murina (M $\phi \mathrm{DM})$........ 41

3.3.3 Análise do fenótipo de macrófagos derivados de medula óssea murina (MфDM) ......42

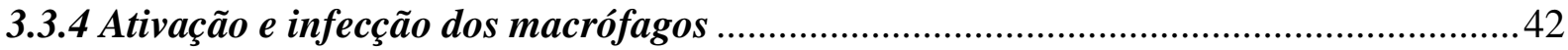

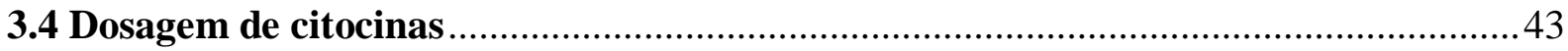

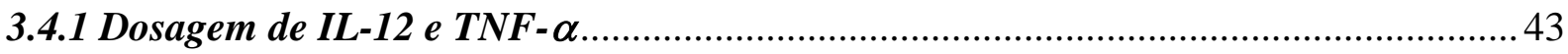

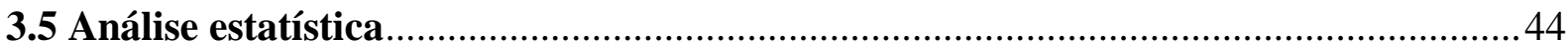

4 RESULTADOS

4.1 Caracterização do fenótipo de $\mathrm{M} \phi \mathrm{DM}$ diferenciados in vitro na presença de M-CSF

4.2 Comparação entre $B$. pertussis e B. parapertussis quanto a capacidade de estimular a

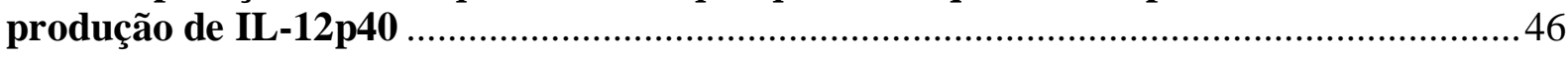

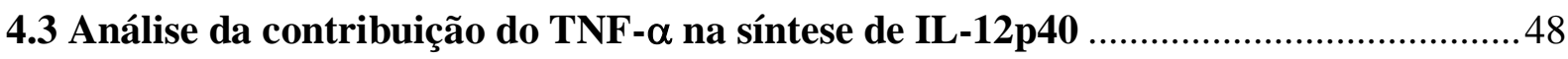

4.3.1 Produção de TNF- $\alpha$ após a ativação in vitro dos M infectados com B. pertussis $\mathrm{e} B$. parapertussis 
4.3.2 Participação do TNF- $\alpha$ na regulação da síntese de IL-12p40 em M antígeno solúvel de B. pertussis $\boldsymbol{e} B$. parapertussis.

4.4 Contribuição dos receptores Toll-like na síntese de IL-12p40 em M $\phi D M$ ativados com antígeno solúvel de $B$. pertussis e $B$. parapertussis

4.4.1 Análise da dependência de sinais emitidos pela molécula adaptadora MyD88

4.4.2 Envolvimento do receptor TLR-4 para a síntese de IL-12p40 durante a ativação de M $\phi D M$ com B. pertussis $e$ B. parapertussis

4.5 Análise da síntese de IL-12p70 em M parapertussis

4.5.1 Ativação dos M $\phi \mathrm{DM}$ com o antígeno solúvel ou infecção ativa

4.5.2 Ação do IFN-y sobre a síntese de IL-12p70 durante a ativação de M $\phi D M$ com B. pertussis e B. parapertussis

4.6 Investigação de vias de sinais intracelulares que controlam a síntese de IL-12p40 durante a ativação de $\mathrm{M} \phi \mathrm{DM}$ com antígeno solúvel de $\boldsymbol{B}$. pertussis e $\boldsymbol{B}$. parapertussis ....61

4.6.1 Efeito do bloqueio específico do NF $\mathrm{KB}$ na síntese de IL-12p40

4.6.2 Efeito de inibidores específicos de MAPkinases p38 e ERK1/2 na produção de IL$12 p 40$ e IL-12p70 durante o estímulo de M $\$ D M$ com antígeno solúvel de B. pertussis ou $B$. parapertussis

4.6.3 Inibição de PI3K regula a síntese de IL-12p70 em M solúvel de B. pertussis ou B. parapertussis.

4.6.4 Regulação da síntese de IL-12p70 por meio da sinalização via proteína Ga inibitória em M 


\section{INTRODUÇÃO}

\subsection{O gênero Bordetella}

O gênero Bordetella compreende bactérias aeróbias, Gram-negativas, cocobacilos que estão associadas a infecções respiratórias em humanos e animais (KERR; MATTHEWS, 2000). Nove espécies pertencem a este gênero: Bordetella pertussis, B. parapertussis, B. bronchiseptica, B. avium, B. hinzii, B. homensii, B. trematum, B. petrii e B. ansorpii. Dentre elas, as três primeiras são estreitamente relacionadas, tendo recebido maior atenção devido à sua importância para saúde pública (WOLFE; KIRIMANJESWARA; HARVILL, 2005).

A B. pertussis, descrita em 1906 por Bordet e Gengou, infecta somente o trato respiratório de humanos causando a coqueluche ou pertussis (CARBONETTI, 2007).

B. parapertussis é o outro agente etiológico da coqueluche humana, embora tenha sido encontrada associada a infecções respiratórias em ovinos (CULLINANE et al., 1987). Análises filogenéticas mostraram que os isolados bacterianos de humanos são distintos dos isolados de carneiros (VAN DER ZEE et al., 1997). Assim, essa bactéria pode ser classificada em dois grupos, um que infecta somente o homem e o outro que infecta apenas ovinos (CUMMINGS et al., 2004).

Bordetella bronchiseptica raramente infecta o homem sendo responsável pela causa de doença respiratória em cães, suínos, caprinos e equinos (WOOLFREY; MOODY, 1991).

Parkhill et al. (2003) sequenciaram o genoma das três espécies de Bordetella descritas acima e mostraram que o genoma de B. pertussis é menor que o de B. parapertussis que por sua vez é menor que o de $B$. bronchiseptica. A diferença no tamanho e a comparação da sequência desses três genomas suportam a hipótese que B. pertussis e B. parapertussis evoluíram independentemente de uma cepa de B. bronchiseptica. Assim, essas três espécies são coletivamente referidas como “B. bronchiseptica cluster" (GERLACH et al., 2001).

Bordetella avium provoca doença respiratória em perus e outras aves, mas não foi encontrada em seres humanos (KERSTERS et al., 1984). Já a Bordetella hinzii foi isolada em aves domésticas (VANDAMME et al., 1995) e em humanos sendo reconhecida como um patógeno oportunista que infecta indivíduos imunocomprometidos (HRISTOV et al., 2008). Bordetella homensii foi associada à septicemia, endocardite e insuficiência respiratória em humanos (TANG et al., 1998). Bordetella trematum foi isolada de feridas e infecções de ouvido em humanos (VANDAMME et al., 1996). Já Bordetella petrii é o primeiro membro 
desse gênero que foi isolado do ambiente sendo capaz de crescer anaerobiamente (VON WINTZINGERODE et al., 2001). E por fim, a Bordetella ansorpii foi isolada do exsudato purulento de um cisto epidérmico humano (KO et al., 2005).

\subsection{Bordetella: Fatores de virulência}

A Bordetella pertussis sintetiza e secreta uma série de fatores de virulência que são classificados em adesinas e toxinas e estão envolvidos na sua patogenicidade (BASSINET et al., 2000).

Dentre as adesinas destaca-se a hemaglutinina filamentosa (FHA), uma proteína com $220 \mathrm{kDa}$, que forma estruturas filamentosas na superfície da bactéria. Ela medeia à adesão de B. pertussis tanto as células ciliadas do epitélio respiratório quanto aos macrófagos (SMITH et al., 2001). Além da FHA, participam do processo de adesão de B. pertussis à célula do hospedeiro, a toxina pertussis (PT), duas fimbrias (tipo 2 e 3), além de uma proteína de membrana externa, a pertactina (PRN) (BASSINET et al., 2000).

A PT é um importante fator de virulência produzido exclusivamente por $B$. pertussis (CARNONETTI, 2010). Essa toxina é uma proteína hexamérica do tipo AB (117 kDa) composta por cinco subunidades distintas (SMITH; GUZMÁN; WALKER, 2001): a subunidade A, também conhecida como S1, possui atividade enzimática. E a subunidade B é composta pelas subunidades S2, S3, duas S4 e S5 (CARNONETTI, 2010).

Os dímeros formados entre S2-S4 e S3-S4 unidos pela subunidade S5 funcionam como adesina, pois se ligam aos receptores celulares fixando a toxina à superfície das células do hospedeiro (células ciliadas do epitélio respiratório e macrófagos alveolares) mediando a entrada de S1 nessas células (CARNONETTI et al., 2007; KERR; MATTHEWS, 2000). No citosol, S1 catalisa a transferência da ADP-ribose do NAD para a subunidade $\alpha$ inibitória da proteína G (Goi) (KATADA; TAMURA; UI, 1983) e assim inibe a atividade dessa proteína (MATOO; CHERRY, 2005). Portanto, a Gai é incapaz de inibir a atividade da adenilato ciclase da célula do hospedeiro que continua ativada promovendo o aumento de AMPc intracelular, o qual interfere no processo metabólico celular e interrompe vias de sinalização. Dessa maneira, tem início os sintomas sistêmicos causados pela infecção com B. pertussis, como a leucocitose, hiperinsulinemia, hipoglicemia e sensibilidade histamínica (CARBONETTI, 2010; LOCHT; COUTTE; MIELCAREK, 2011). 
As manifestações clínicas da infecção causada por B. pertussis geralmente são muito mais severas se comparada a de B. parapertussis (MASTRANTONIO et al., 1998), possivelmente pelo fato do gene responsável pela síntese da PT não ser transcrito em $B$. parapertussis e $B$. bronchiseptica devido a mutações na região promotora (ARICO; RAPPUOLI, 1987).

A toxina adenilato ciclase (ACT ou CyaA) é secretada por todas as espécies de Bordetella que infectam mamíferos (MATOO; CHERRY, 2005) e também induz o aumento de AMPc intracelular, porém de modo diferente ao descrito para PT. O alvo da ACT são as células fagocíticas por se ligar especificamente ao receptor de superfície, $\alpha \mathrm{M} \beta 2$ integrina ou CR3 (também conhecido como Mac-1 ou CD11b/CD18). Após entrar nas células eucarióticas, a ACT é ativada pela calmodulina no citoplasma e converte ATP em AMPc (CARBONETTI, 2010). Essa toxina requer cálcio para adquirir mudanças conformacionais que resultam na sua translocação através da membrana para o interior da célula alvo (LADANT; ULMANN, 1999). O aumento dos níveis de AMPc nas células do hospedeiro leva a um processo de intoxicação (GRAY et al., 1998). As consequências da intoxicação são: alteração da capacidade fagocítica, toxicidade celular e indução de apoptose em macrófagos (KHELEF; ZYCHLINSKY; GUISO, 1983), permitindo a persistência de B. pertussis no hospedeiro e a progressão da infecção (GUEIRARD et al., 1998). Além disso, a ACT pode formar pequenos poros seletivos de cátion que são importantes para a sua atividade hemolítica sobre eritrócitos (CARBONETTI, 2010).

Já a citotoxina traqueal (TCT) é um fragmento de peptideoglicano bacteriano de 921 Da (WING). Essa toxina provoca destruição da célula epitelial ciliada respiratória, porém seu mecanismo de ação sobre as células alvo é desconhecido (KERR; MATTHEWS, 2000). Ela também estimula a síntese de IL-1 que regula a temperatura corporal através da sua ligação a receptores termoreguladores no hipotálamo resultando em febre (WING). A destruição das células epiteliais ciliadas pela TCT força o indivíduo infectado a tossir incansavelmente na tentativa de remover o muco produzido pelas células caliciformes (LUKER et al., 1993).

A toxina dermonecrótica (DNT) possui $120 \mathrm{kDa}$, causa inflamação, vasoconstrição e necrose local ao redor das áreas colononizadas por $B$. pertussis no trato respiratório (BADU et al., 2001). Essa toxina é termolábil sendo inativada a $56^{\circ} \mathrm{C}$ (SMITH; GUZMÁN; WALKER, 2001).

Outro componente, a endotoxina LPS (lipopolissacarídeo) de B. pertussis é um potente estimulador das respostas imunológicas (MURRAY et al., 2004). 
O LPS bacteriano é encontrado na dupla camada lipídica externa que circunda as paredes celulares de bactérias Gram-negativas. Cada molécula de LPS consiste em um cerne de carboidrato ligado, em um dos lados, ao fosfolipídio (denominado lipídio A) ancorado na dupla camada e, do outro lado, há uma longa cadeia de polissacarídeo denominado antígeno $\mathrm{O}$, que se estende externamente a partir da superfície bacteriana. O lipídio A é responsável pelos efeitos pró-inflamatórios do LPS, enquanto o antígeno O é altamente variável em LPS de diferentes espécies de bactéria (FUJIHARA et al., 2003).

A molécula do LPS de B. pertussis é menor do que o de outras bactérias, diferindo na sua estrutura pela falta do antígeno $\mathrm{O}$, devido a uma deleção de $20 \mathrm{~kb}$ do locus wbm que contém o gene para a biosíntese do antígeno O (GOEBEL et al., 2008; PRESTON et al., 2006). Já o antígeno O expresso em B. parapertussis e B. bronchiseptica são similares, mas possivelmente desempenham papéis diferentes durante a infecção (BURNS et al., 2003). Quanto a estrutura do lipídio A de B. pertussis, B. bronchiseptica, B. parapertussis e B. hinzii há diferença na distribuição das suas cadeias de ácidos graxos, conforme pode ser visto na figura 1 (CAROFF et al., 2002).

Figura 1 - Estrutura do lipídio A do LPS de quatro espécies do gênero Bordetella, destacando o número e distribuição das cadeias de ácidos graxos.
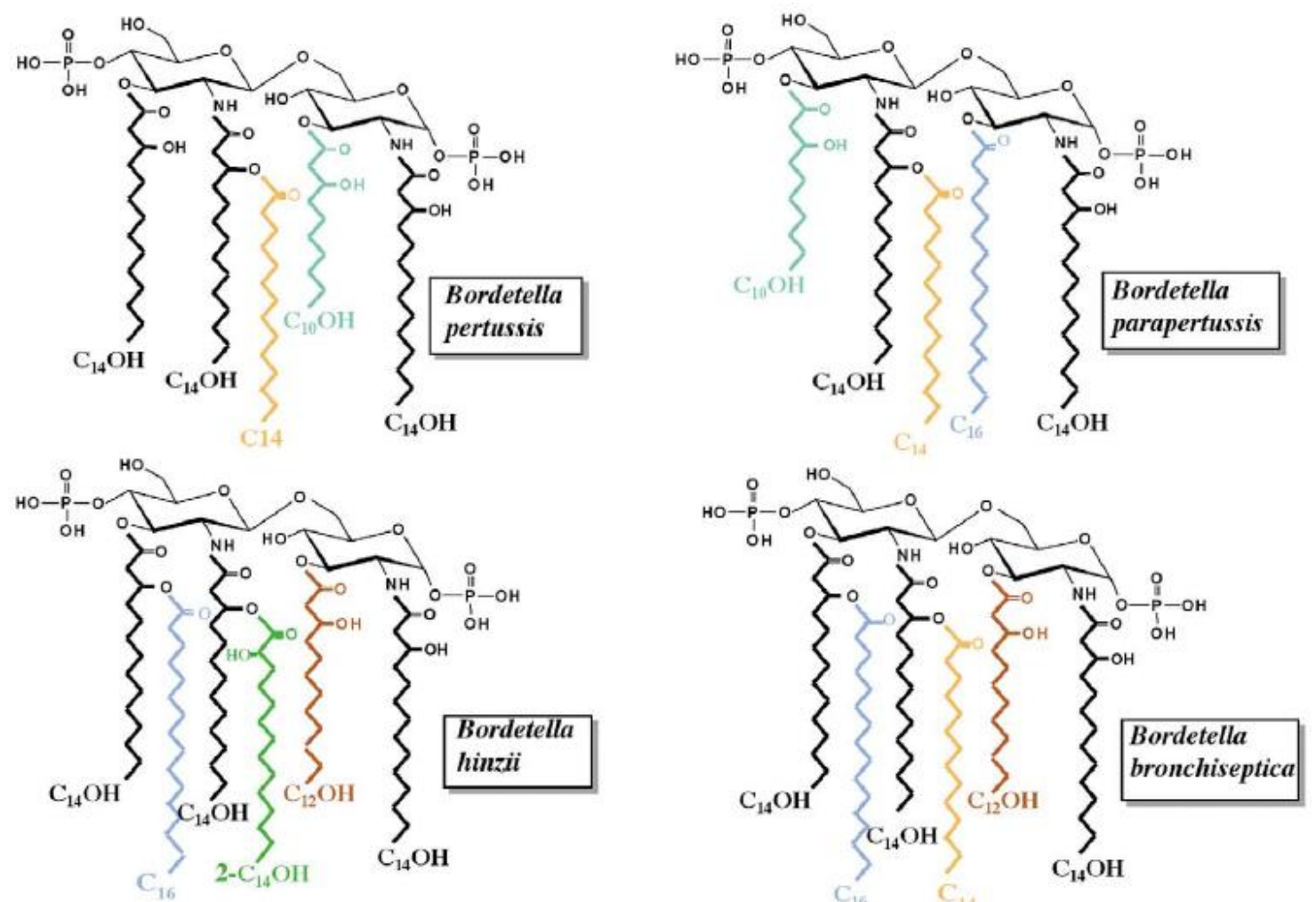

Cada cor representa um determinado ácido graxo mostrando a diferença na estrutura do lipidio A entre as bactérias.

Fonte: Caroff et al. (2002). 
Apesar das diferenças na estrutura do LPS, as demais adesinas e toxinas como: FHA, PRN, fímbrias, ACT, DNT e TCT são encontradas em B. pertussis, B. parapertussis e $B$. bronchiseptica (PARKHILL et al., 2003).

A expressão de muitos dos fatores de virulência de Bordetella é controlada em reposta ao estímulo ambiental usando um sistema regulatório de dois componentes chamado BvgA/S. A temperatura de $37^{\circ} \mathrm{C}$, na ausência de sulfato de magnésio $\left(\mathrm{MgSO}_{4}\right)$ e de ácido nicotínico, a proteína BvgS localizada na membrana interna, que detecta as mudanças no ambiente é autofosforilada, utilizando ATP como doador de grupo fosfato (LOCHT, 1999). Após diversas etapas de fosforilação, o grupo fosfato é finalmente transferido para o domínio amino-terminal da proteína BvgA (LOCHT; ANTOINE; JACOB-DUBUISSON, 2001). Essa proteína fosforilada ativa a transcrição de vários genes de virulência ativados (vags) por se ligar em seus promotores (Figura 2). Um desses genes codifica o regulador BvgR que reprime a transcrição de outros genes denominados genes de virulência reprimidos (vrgs). Assim, a ativação de Bvg muda o perfil da expressão gênica da bactéria. Muitos genes implicados na patogênese são altamente expressos quando o sistema Bvg está ativo, sugerindo que a fase $\mathrm{Bvg}^{+}$é importante para a bactéria entrar na célula hospedeira. Por outro lado, a fase $\mathrm{Bvg}^{-}$é expressa quando a bactéria está no ambiente em condições desfavoráveis como por exemplo a temperatura baixa (PARKHILL et al., 2003).

\section{Figura 2 - Representação esquemática do sistema de dois componentes BvgA/S de Bordetella.}

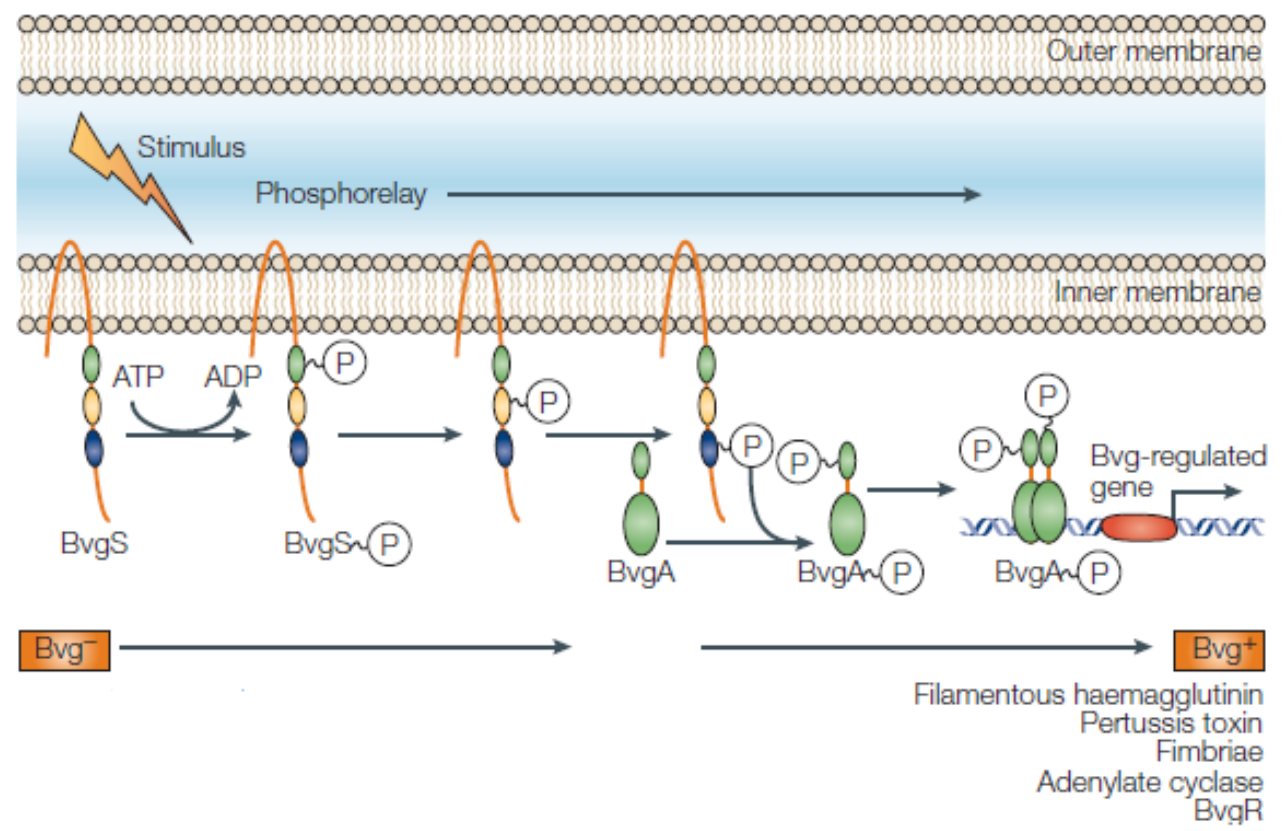

Fonte: Modificado de Preston, Parkhill e Maskell (2004). 
B. pertussis, B. parapertussis e B. bronchiseptica compartilham um sistema de controle de virulência codificado pelo locus bvgAS similar (MATOO; CHERRY, 2005) que influencia a capacidade da bactéria regular a expressão gênica de fatores de virulência dependendo das mudanças ambientais e, portanto, é importante para o estabelecimento da infeccção, persistência, evasão da resposta imune e transmissão (KERR; MATTHEWS, 2000; KINNEAR; MARQUES; CARBONETTI, 2001).

\subsection{Aspectos epidemiológicos e controle da infecção por Bordetella}

A coqueluche ou pertussis, conhecida popularmente como tosse comprida, é uma doença infecciosa aguda, transmissível, caracterizada por clássicos paroxismos de tosse. Sua prevalência é universal e apesar de ser muito severa em crianças pode ocorrer em indivíduos de qualquer idade (VERSTEEGH; SCHELLEKENSB; ROORDD, 2005).

A frequência de ocorrência da coqueluche causada por B. parapertussis está entre 2 e 36\%, dependendo do país (DAVID; VAN FURTH; MOOI, 2004). Embora esta infecção tenha menor incidência e quadro clínico mais ameno se comparada à infecção por $B$. pertussis, seu papel não pode ser minimizado, uma vez que as vacinas atuais protegem contra B. pertussis, mas não contra B. parapertussis (ZHANG et al., 2009).

Esta doença é importante causa de mortalidade infantil no mundo e continua sendo um problema de saúde pública mesmo em países com alta cobertura vacinal. Estimativas da OMS (Organização Mundial da Saúde) mostraram que em 2008, cerca 16 milhões de casos de coqueluche ocorreram em todo o mundo, $95 \%$ dos quais em países em desenvolvimento, e cerca de 195.000 crianças morreram da doença (BLACK et al., 2010).

Em países da Ásia, África e América do Sul os relatos epidemiológicos da coqueluche são limitados, porém estimativas da OMS demonstraram que esses países têm alta incidência da doença. Estimar o número de casos de coqueluche é difícil devido à falta de acesso a métodos de diagnóstico, subnotificação e diagnósticos equivocados, pois os sintomas desta infecção podem ser confundidos com outras espécies de Bordetella, vírus e bactérias (FORSYTH et al., 2007; WOOD; MCINTYRE, 2008). Além disto, pertussis é uma das 10 principais causas de morte em crianças menores de um ano em todo o mundo (WOOD; MCINTYRE, 2008).

No Brasil, a coqueluche é uma doença de notificação compulsória. Os casos suspeitos devem ser notificados ao Sistema de Vigilância Epidemiológica pelo SINAN (Sistema de 
Informação de Agravos de Notificação) (BRASIL, 2009). As crianças menores de um ano de idade, especialmente com menos de seis meses, são o grupo que apresenta taxas de incidência e letalidade mais acentuadas (PEREIRA, 2010).

Em 2011 foram confirmados 2257 casos de coqueluche notificados ao SINAN no Brasil e registrados 55 óbitos, sendo 53 de crianças menores de um ano. O maior número de casos confirmados foi no estado de São Paulo. Em 2012, o número de casos dobrou em relação ao ano anterior sendo confirmados 4864 casos. Foram registradas 79 mortes de crianças menores de um ano. Além de São Paulo outros estados com alta incidência foram Espírito Santo e Rio Grande do Sul. O critério laboratorial foi utilizado para a confirmação da maioria dos casos relatados nesses dois anos (SINAN).

Na Califórnia, somente em 2010, do total de 27.550 notificações em todo território norte-americano foram confirmados 9.774 casos pelos Centros de Prevenção e Controle de Doenças (CDC). Dez bebês com apenas dois meses de idade morreram durante o surto. Na Europa foram confirmados 15.749 casos em 2010, sendo 46\% deles na Noruega e na Holanda. Na Austrália, houve 35 mil registros entre os meses de julho de 2010 e 2011 (BARRA, 2011).

Em países como a Argentina, Chile e Colômbia foram relatados 1.042, 348 e 2.581 casos de coqueluche, respectivamente no primeiro semestre de 2012 (LU FERNANDES, 2012). Enquanto em Washington, o número de casos foi de 2.520 (CENTERS FOR DISEASE CONTROL AND PREVENTION, 2012).

Atualmente tenta-se compreender porque a coqueluche tem reemergido em populações vacinadas. Algumas hipóteses foram levantadas para explicar este fato (CARVALHO; PEREIRA, 2006):

1) possível modificação genética das bactérias tornando as vacinas menos eficazes;

2) disponibilidade de melhores testes diagnósticos;

3) perda da imunidade adquirida por meio da vacina, na ausência de reforços vacinais, após 5 a 10 anos. Este último aspecto já seria suficiente para explicar a ocorrência da doença entre adolescentes e adultos (LUZ; CODEÇO; WERNECK, 2003). Segundo Jenkinson (1988), a imunidade é completa somente no primeiro ano após a imunização caindo gradualmente com o passar do tempo, tendo $84 \%$ de eficácia após quatro anos, aproximadamente $50 \%$ nos três anos seguintes e após 12 anos nenhuma proteção foi evidenciada.

A infecção por este microrganismo se dá pela inalação da bactéria presente em aerossóis e gotículas provenientes de secreção da orofaringe que são eliminadas por tosse, 
espirro ou ao falar. A transmissão ocorre, principalmente, pelo contato direto do portador da doença com a pessoa susceptível (BRASIL, 2005).

Embora B. pertussis tenha sido descrita como um microrganismo extracelular, produzindo adesinas e toxinas na superfície do epitélio respiratório, alguns estudos demonstraram que essa bactéria pode aderir e invadir as células epiteliais (BASSINET et al., 2000), persistir intracelularmente em macrófagos alveolares murinos, além de invadir e sobreviver dentro de macrófagos e leucócitos polimorfonucleares humanos (STEED; AKPORIAYE; FRIEDMAN, 1992).

O período de incubação pode variar entre 6 e 21 dias, mas é tipicamente de 7 a 10 dias (TOZZI et al., 2005). Após esse período, tem-se a manifestação da infecção que geralmente começa com a secreção nasal, mal-estar, anorexia, febre baixa e tosse progressiva. Esse estágio é denominado catarral. Nessa fase a doença é mais contagiosa e é clinicamente indistinguível de uma infecção leve do trato respiratório superior. Depois de 1 ou 2 semanas, inicia-se o estágio paroxístico que é caracterizado pelos clássicos paroxismos de tosse (série de tosses seguidas de guincho inspiratório). O guincho é conhecido como um ruído típico. Os paroxismos terminam frequentemente com vômito e exaustão (COVISA, 2009).

Após 2 a 6 semanas a doença entra na fase de convalescença que dura de 1 a 3 semanas e caracteriza-se pela redução da intensidade e gravidade dos paroxismos, mas podem ocorrer complicações secundárias (MURRAY et al., 2004) como broncopneumonia e encefalopatia que, frequentemente, se manifesta por convulsões (TRABULSI; ALTERTHUM, 2005).

A infecção por B. pertussis é diagnosticada por cultura de secreções da nasofaringe, PCR (Reação em cadeia da polimerase) e teste sorológico por meio de ELISA. Esse teste é baseado na identificação de uma significativa variação de títulos de $\operatorname{IgG}$ ou $\operatorname{Ig}$ A contra alguns fatores de virulência da bactéria como FHA, PRN, PT, fimbrias (FIM) (TOZZI et al., 2005; MATTOO; CHERRY, 2005). O resultado deste teste é baseado em um valor de corte (cut off) de concentração de anticorpo definido para cada antígeno (GUISO et al., 2011).

O tratamento da coqueluche é feito com a eritromicina, porém há isolados de $B$. pertussis resistentes a esse antibiótico (KORGENSKI; DALY, 1997). Azitromicina e claritromicina também são efetivos para o tratamento de pertussis (LANGLEY et al., 2004; LEBEL; MEHRA, 2001). O tratamento com antibióticos elimina a bactéria, se este for iniciado durante o estágio catarral ou início do estágio paroxístico, promovendo a redução do período de transmissão, duração e severidade da doença (BRASIL, 2005; COVISA, 2009; MARCHANT; CHANG, 2009). 
As vacinas preparadas com a B. pertussis morta (Whole cell) estão disponíveis a mais de 50 anos, sendo um dos componentes da vacina tríplice bacteriana (DTP) que protege também contra a difteria e o tétano. Ela é preparada com células bacterianas obtidas da cultura em meios líquidos, submetidos à inativação por formaldeído, calor ou timerosal (DIAS et al., 2007). A vacina tríplice bacteriana é recomendada a partir de 2 meses de idade. As crianças devem receber três doses até 1 ano de idade, um reforço aos 15 meses e outro entre 4 a 6 anos. A DTP pode ser administrada concomitante a outras vacinas (LIPHALUS; GONÇALVES; CARVALHANAS, 2008). Apesar de ser muito eficiente, a vacina celular mostrou em alguns casos uma série de reações adversas que incluem choros prolongados, irritabilidade, convulsões febris, episódio hipotônico-hiporresponsivo caracterizado por palidez, diminuição ou desaparecimento do tônus muscular ou ausência de resposta a estímulos, e reações locais como vermelhidão e edema (MARZOUQI et al., 2010).

Estas preocupações motivaram o desenvolvimento da vacina pertussis acelular em 1970 que consiste de um a cinco antígenos de B. pertussis (FHA, PRN, PT inativada e fímbrias 2 e 3). A maioria das preparações difere entre si quantitativamente em relação às concentrações dos componentes antigênicos utilizados (DIAS et al., 2007). Na vacina acelular para adolescentes e adultos a quantidade de toxóide diftérico e dos componentes pertussis difere das preconizadas para crianças. No Brasil existem duas formulações licenciadas: uma composta por três componentes da bactéria para uso em pessoas com mais de 11 anos de idade (BRICKS, 2007) e outra composta por cinco componentes lançada em 2011 como dose de reforço para crianças a partir de 3 anos, adolescentes e adultos (SANOFI, 2011).

O Instituto Butantan desenvolveu nos últimos anos uma vacina whole cell com baixo teor de LPS que foi denominada de $\mathrm{P}_{\text {low }}$ (DIAS et al., 2007).

O custo da DTP whole-cell é de US\$ 0,15/dose, enquanto o da vacina DTP acelular é de US\$ 8,15 (RAW; HIGASHI, 2008). A formulação da DTP acelular possui custo elevado, pois requer várias etapas cromatográficas de purificação do sobrenadante ou filtrado da cultura, a fim de obter cada um dos componentes antigênicos da vacina (DIAS et al., 2007).

A imunização de adolescentes e adultos com a vacina pertussis acelular constitui uma estratégia para controlar a reemergência da doença e poderia ser administrada em adição a dose reforço da vacina dT (difteria, tétano) que não contém o componente pertussis. A vacina dT é utilizada a partir de 7 anos de idade com reforços a cada dez anos (LIPHALUS; GONÇALVES; CARVALHANAS, 2008). A partir do segundo semestre de 2013, as gestantes brasileiras passarão a ser vacinadas com a DTPa (vacina tríplice acelular) com o objetivo de garantir que o bebê já nasça com alguma proteção contra a coqueluche, evitando 
que a infecção ocorra antes dos 6 meses de idade e também que a mãe seja fonte de infecção para o seu próprio filho (LABOISSÈRE, 2013).

No entanto, ainda é necessário melhorar o rendimento protéico dos antígenos, reduzir o custo da vacina acelular e desenvolver vacinas que proporcionem proteção a longo prazo, pois a imunidade conferida pelas vacinas atuais duram em média 10 anos. As vacinas de DNA utilizando genes que codificam PT, FHA e PRN; mutantes vivos atenuados e antígenos dessa bactéria encapsulados em partículas biodegradáveis representam potenciais alternativos para as vacinas existentes (MARZOUQI et al., 2010).

Em modelo murino, imunizações com os componentes da vacina acelular, com a vacina celular, a infecção ativa com B. pertussis (KHELEF et al., 1993) ou transferência passiva de soro imune (WATANABE; NAGAI, 2003) não protegeu os animais quando estes foram infectados com B. parapertussis, porém, houve proteção contra a espécie homóloga. Isto sugere que cada uma dessas espécies de Bordetella pode modular diferentemente a resposta imune do hospedeiro devido em parte às diferenças quanto à expressão e estrutura de alguns fatores de virulência. Além disso, aspectos que envolvem as interações parasitahospedeiro nestas infecções não estão completamente esclarecidos (MARTINS, 2006), indicando a necessidade de novos estudos neste sentido.

\subsection{O papel dos macrófagos na imunidade inata e a síntese de IL-12}

As células sanguíneas derivam de uma célula-tronco hematopoiética pluripotente da medula óssea que se diferencia em duas linhagens: a linfóide que dá origem aos linfócitos e a mielóide que origina os eritrócitos, granulócitos, monócitos e plaquetas (VALLEDOR et al., 1998).

Os monócitos da circulação periférica migram para os tecidos e se diferenciam em macrófagos (MURRAY; WYNN, 2011) e na presença de componentes de microrganismos, mediadores da inflamação ou outros sinais de lesão tecidual aumentam seu metabolismo, motilidade e atividade fagocítica visando o combate de vários patógenos e reparo tecidual (ZANONI; GRANUCCI, 2009).

As principais funções dos macrófagos são: fagocitose, processamento e apresentação de antígenos aos linfócitos T, além de liberação de citocinas, quimiocinas e outros mediadores envolvidos na resposta imune. Estas células possuem vários receptores de superfície que 
auxiliam no reconhecimento, fagocitose e destruição de patógenos (GEISSMANN et al., 2010; MURRAY; WYNN, 2011).

\subsubsection{Os receptores Toll-like na ativação da imunidade inata}

Os receptores Toll-like (TLRs) são proteínas transmembrana que reconhecem estruturas conservadas presentes em patógenos denominadas de padrões moleculares associados a patógenos (PAMPs) e ativam vias de sinalização intracelular (MOGENSEN, 2009) que resultam na produção de citocinas e na regulação de moléculas de superfície celular essenciais para a resposta imune inata e adaptativa (MANN et al., 2005). Além dos TLRs, outras classes de receptores de reconhecimento padrão (PRRs) foram descritas e incluem os receptores intracelulares NOD-like (NLRs), os receptores de gene 1 induzido por ácido retinóico, RIG-1-like (RLRs) e os receptores de lectina tipo C (CLRs) (TAKEUCHI; AKIRA, 2010).

Os TLRs foram identificados em vertebrados com base na sua homologia a proteína Toll encontrada em Drosophila, importante na defesa destes insetos contra fungo. Em humanos foram identificados 10 membros de TLRs e em camundongos 13 (KUMAR; KAWAI; AKIRA, 2009). O TLR-10 é expresso em humanos, mas não em camundongos. O TLR-10, TLR-12 e TLR-13 não estão bem caracterizados e suas funções ainda não foram esclarecidas (KUMAR; KAWAI; AKIRA, 2011).

Alguns TLRs são expressos sobre a superfície celular (TLR-1, 2, 4, 5, 6, 10 e 11) enquanto outros estão localizados em compartimentos intracelulares (TLR-3, 7, 8, 9). Cada TLR reconhece um PAMP específico, assim os TLRs são capazes de reconhecer diversos microrganismos (MOGENSEN, 2009). Por exemplo, TLR-2 reconhece lipoproteínas bacterianas, peptideoglicano, glicolipídio micobacteriano e zymozan (polissacarídeo de Saccaromyces cerevisiae); TLR-3 reconhece dupla fita de RNA viral; TLR-4 reconhece LPS de bactérias Gram-negativas; TLR-5 reconhece a flagelina; TLR-7 e TLR-8 reconhecem RNA simples fita, TLR-9 reconhece DNA bacteriano não metilado $(\mathrm{CpG})$ e TLR-11 reconhece profilinas de Toxoplasma gondii e Escherichia coli uropatogênica (KUMAR; KAWAI; AKIRA, 2009) (Figura 3). O reconhecimento dos PAMPs pelos seus respectivos TLRs leva a ativação do fator de transcrição nuclear NFKB que é translocado do citoplasma para o núcleo e controla a transcrição de genes importantes para ativação da resposta imune (BONIZZI; KARIN, 2004). 
Após o reconhecimento do PAMP, as moléculas adaptadoras citosólicas contendo o domínio TIR se ligam ao domínio TIR de TLRs. Como observado na figura 3, são quatro as moléculas adaptadoras: MyD88 (proteína de diferenciação mielóide 88), TIRAP/Mal que liga TLR ao MyD88, TRIF (também chamado de TICAM1) e TRAM que liga o TLR-4 ao TRIF (KUMAR; KAWAI; AKIRA, 2009). O TLR-1, TLR-2, TLR-4 e TLR-6 recrutam TIRAP para iniciar a sinalização dependente de MyD88 (KUMAR; KAWAI; AKIRA, 2011). A molécula MyD88 é utilizada por todos os TLRs, exceto o TLR-3, o qual requer o TRIF como molécula adaptadora (KOH et al., 2010). O TLR-4 é o único que utiliza os quatro adaptadores (KUMAR; KAWAI; AKIRA, 2009). Dessa maneira, duas vias de sinalização podem ser ativadas em resposta aos TLRs, uma dependente e outra independente de MyD88.

\section{Figura 3 - PAMPs reconhecidos pelos diferentes TLRs e suas moléculas adaptadoras}

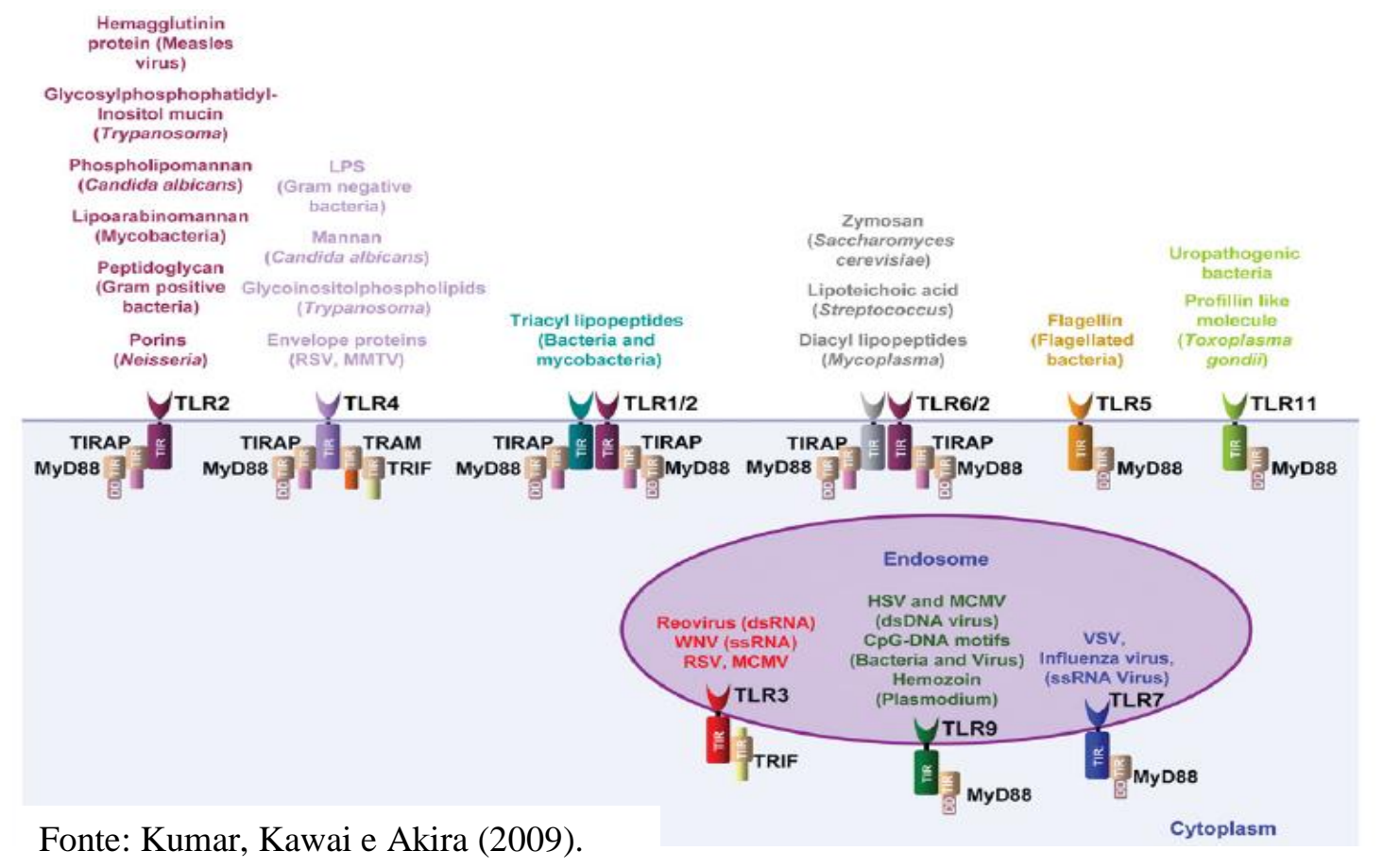

A via dependente comum aos TLRs ativa NFkB e as MAPKs (proteínas quinases ativadas por mitógenos) para produção de citocinas inflamatórias como TNF- $\alpha$ e IL-1, IL-6 e IL-12, essenciais para a eliminação de microrganismos (ZHANG; DONG, 2005; KAWAI; AKIRA, 2006). Enquanto que a via independente de MyD88 é mediada por sinais que envolvem TLR-3 e TLR-4 e ativa os fatores reguladores de interferon (IRF) 3 e 7 que induzem IFN do tipo I, particularmente o IFN- $\beta$, que é importante para a resposta imune do hospedeiro contra vírus. Essa via também está envolvida com a ativação de NFKB e MAPKs (KAWAI; AKIRA, 2006; KUMAR; KAWAI; AKIRA, 2011). 
A molécula MyD88 é essencial para a estimulação de citocinas pró-inflamatórias como TNF- $\alpha$, IL-1 $\beta$, IL-12 e IL-6 em resposta aos agonistas de TLR (NETEA et al., 2004). Assim, camundongos deficientes em MyD88 são altamente susceptíveis a infecção com uma grande variedade de patógenos, incluindo Staphylococcus aureus, Listeria monocytogenes e Toxoplasma gondii, indicando um importante papel desta molécula na resistência do hospedeiro a infecção microbiana (FENG et al., 2003). No entanto, foi observado que a capacidade fagocítica dos macrófagos de camundongos MyD88 ${ }^{-/-}$permanece intacta (NETEA et al., 2004) e suas células mantém a capacidade de ativar NFkB e MAPK, sendo essa ativação tardia em comparação com o camudongo selvagem (KAWAI; AKIRA, 2006).

Apesar do LPS induzir a resposta inflamatória via TLR-4, foi sugerido que o TLR-2 pode interagir com o LPS de algumas bactérias não entéricas (GIRARD et al., 2003). A importância de TLR-4 no controle da infecção por B. pertussis tem sido objeto de intenso estudo nos últimos anos (BANUS et al., 2006).

O lipídio A da molécula de LPS é reconhecido por um complexo constituído por TLR4, MD-2 (proteína de diferenciação mielóide 2) e CD14 (MARR et al., 2010). Para isso, o LPS se liga a proteína plasmática de ligação do LPS (LBP) que catalisa a transferência do LPS para o CD14 na superfície da célula. Isso forma um complexo com TLR-4 e MD-2 que está associado ao domínio extracelular de TLR-4 (MIYAKE, 2004).

O domínio citoplasmático do TLR-4 interage com MyD88 recrutando membros da família de proteínas quinases associadas ao receptor de IL-1 (IRAKs) que são ativadas por fosforilação e interagem com o fator 6 associado ao receptor de TNF (TRAF-6) (MONGENSEN, 2009; TAKEDA; AKIRA, 2004). Isto promove a ativação de MAPKs e do

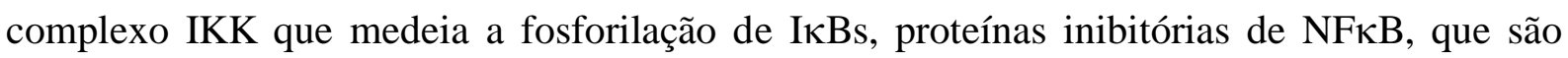

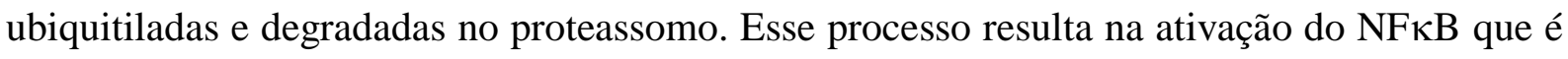
translocado para o núcleo (GHOSH; MAY; KOPP, 1998; MIYAKE, 2004) onde inicia a transcrição de genes que codificam quimiocinas, citocinas, moléculas co-estimulatórias, moléculas de adesão endotelial, além de enzimas como a óxido nítrico sintase induzida (iNOS) e inibidores de apoptose (BONIZZI; KARIN, 2004; JONES et al., 2001) (Figura 4). A ativação das MAPKs resulta na fosforilação e indução de outro fator de transcrição, AP-1, que assim como o NFKB pode regular genes de citocinas (TAKRUCHI; AKIRA, 2010).

Durante a sinalização mediada por TLR-3 e TLR-4, a molécula TRIF se associa com TRAF-6 e a proteína 1 de interação com o receptor (RIP1) ativando NFкB e MAPKs, além de se associar com o TRAF-3 que é responsável pela fosforilação de IRF-3 e IRF-7. Em seguida, 
estes IRFs fosforilados são translocados para o núcleo e induzem a transcrição de genes de interferons do tipo I (KUMAR; KAWAI; AKIRA, 2009; TAKEUCHI; AKIRA, 2010) como ilustrado na Figura 4 abaixo.

\section{Figura 4 - Vias de sinalização mediadas por TLR-4 e TLR-3}

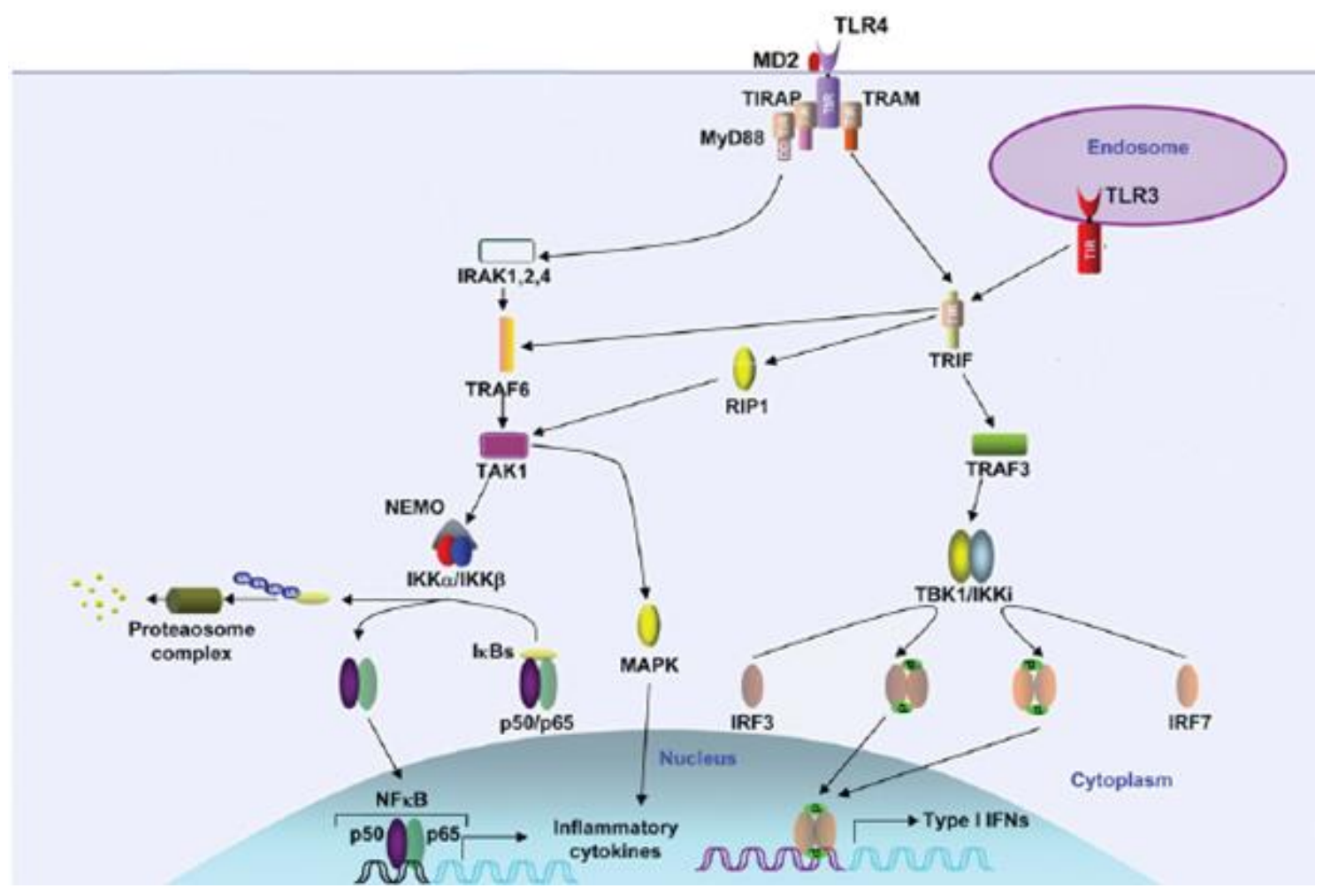

TLR-4 ativa a via dependente e a independente de MyD88, a via dependente de TRIF. A via dependente de MyD88 ativa NFkB e as MAPKs (p38, ERK 1/2 e JNK) que controla a produção de citocinas inflamatórias. A via independente de MyD88 ativa IRF3 e IRF7, importantes para induzir IFNs do tipo I. TLR-3 localizado no endossomo utiliza somente a via independente de MyD88. Fonte: Modificado de Kumar, Kawai e Akira (2009).

As MAPKs são serinas/tirosinas quinases ativadas por fosforilação em resposta aos sinais extracelulares e modulam a expressão gênica no núcleo (KIM; KIM; SHARMA, 2004). Elas são importantes para a proliferação celular, resposta a estresse, apoptose e imunidade (LIU; SHEPHERD; NELIN, 2007). Em mamíferos há três grupos principais de MAPKs: extracellular signal-regulated kinases (ERKs), c-jun amino-terminal kinases (JNKs) e p38 MAP kinases (COBB; GOLDSMITH, 1995). ERK1 (p44) e ERK2 (p42) são preferencialmente ativadas em resposta a fatores de crescimento e ésteres de forbol, enquanto JNK e p38 MAPKs são sensíveis aos estímulos de estresse ambiental como o choque osmótico, a radiação ionizante e a estimulação por citocinas como TNF- $\alpha$ e IL-1 (LU et al., 1999; ROUX; BLENIS, 2004). 
Estímulos via TLRs também podem ativar a enzima fosfatidilinositol 3 quinase (PI3K) (KRISHNAN et al., 2007). A PI3K regula vários processos celulares como a proliferação, crescimento, apoptose e rearranjo do citoesqueleto (RUSE; KNAUS, 2006; VANHAESEBROECK et al., 2001).

Uma vez ativada, a PI3K cataliza a geração de um segundo mensageiro que ativa Akt, também conhecida como proteína quinase B. Essa via de sinalização pode ser ativada por vários receptores de superfície celular como receptores $\mathrm{Fc}$, de insulina (CREMER; BUTCHAR; TRIDANDAPANI, 2011) e receptores ligados a proteína G (DEANE; FRUMAN, 2004). A via PI3K-Akt é importante na regulação da produção de mediadores inflamatórios em monócitos/macrófagos humanos e murinos (MARTIN et al., 2003).

\subsubsection{O papel da IL-12 na resposta imune}

A IL-12 é produzida principalmente por células apresentadoras de antígenos (APC) como macrófagos e células dendríticas favorecendo o controle de infecções e o estabelecimento da imunidade protetora (LAMONT; ADORINI, 1996; TRINCHIERI, 1995). Esta citocina é produzida devido à exposição de APCs a patógenos e seus produtos, independente da presença de células T, no entanto a interação da molécula CD40L presente em linfócitos T e CD40 expresso em APCs pode acentuar a sua liberação (MARRIOTT; CLARKE; DALGLEISH, 2001). Os neutrófilos e em menor extensão os linfócitos B também sintetizam IL-12 (WATFORD et al., 2003).

Essa citocina é um heterodímero composto de duas subunidades, uma de $35 \mathrm{kDa}$ (p35) e uma de $40 \mathrm{kDa}$ (p40) ligadas por ponte de dissulfeto. A subunidade p40 é compartilhada pela IL-12 e IL-23 que neste caso está associada à subunidade p19 (VECCHIO et al., 2007). Seu receptor IL-12R também consiste de duas subunidades: a $\beta 1$, que interage com a IL12p40, e a $\beta 2$ que interage com a IL-12p35 (PRESKY et al., 1996).

A forma biologicamente ativa, IL-12p70, é fundamental para a resposta imune a tumores, parasitas intracelulares, fungos, bactérias e vírus (ZHANG; WANG, 2008). Produtos microbianos como LPS, ácido lipoteicóico (LTA), peptideoglicano e DNA bacteriano (CpG) induzem a produção dessa citocina (WATFORD et al., 2003).

Em humanos, o gene da subunidade p40 se localiza no cromossomo 5 e o gene da p35 no cromossomo 3, enquanto em camundongos, os genes p35 e p40 se localizam nos cromossomos 3 e 11, respectivamente (ROMANI; PUCCETTI; BISTONI, 1997). A 
subunidade p40 murina e p40 humana possui $70 \%$ de identidade, enquanto p35 murina tem $60 \%$ de identidade (SCHOENHAUT et al., 1992).

A subunidade p40 é secretada de 10 a 100 vezes mais em relação a IL-12p70, indicando que a produção das subunidades p35 e p40 é diferentemente regulada (TRINCHIERI, 1996). A subunidade p40 também pode formar um homodímero, IL-12p80 ou IL-12(p40) 2 que atua como antagonista da IL-12 e IL-23 por competir com seus receptores (HÖLSCHER, 2004; NIGG et al., 2007).

Foi sugerido inicialmente que p35 seria expressa constitutivamente em vários tipos celulares, enquanto que a transcrição de p40 seria altamente regulada e assim, a produção da subunidade p40 seria indicativa da expressão do heterodímero IL-12p70 (MURPHY et al., 1995). Porém, posteriormente, observou-se que a expressão de p35 também pode determinar o nível de produção do heterodímero IL-12p70, pois essa subunidade pode não ser sintetizada pelas células (BABIK et al., 1999; SNIJDERS et al., 1996).

A regulação da subunidade p40 se dá a nível transcricional enquanto a subunidade p35 é regulada tanto em nível de transcrição como de tradução. O promotor do gene p40 humano e murino contém sítios de ligação para diversos fatores de transcrição como NFкB e IRF-1 (membro da família de fatores reguladores de interferon) (KANG; KIM; KIM, 2005).

A produção da IL-12 é regulada por diversos fatores, dentre eles: AMP cíclico, canais de íons na membrana celular, óxido nítrico, MAPK p38 (KANG; KIM; KIM, 2005) e PI3K (FUKAO et al., 2002). Além disso, a sinalização via proteína Gai pode controlar a síntese de IL-12 e a diferenciação de subpopulações de linfócitos Th1 (HE et al., 2000). Como a PT atua sobre a proteína Gai, ela pode contribuir com a regulação desta citocina durante a infecção com B. pertussis.

Esta citocina aumenta a atividade fagocítica e bactericida dos macrófagos, atua na geração de outras citocinas pró-inflamatórias e direciona o desenvolvimento da resposta celular Th1 (GOODRIDGE et al., 2003). A IL-12 ativa as células NK (Natural Killer) e linfócitos Th1 a produzirem IFN- $\gamma$, além de aumentar a atividade citotóxica das células NK e dos linfócitos $\mathrm{T} \mathrm{CD}^{+}$ativados por promover a transcrição de genes que codificam fatores citolíticos incluindo a perforina e as granzimas (TRINCHIERI, 2003).

$\mathrm{O}$ IFN- $\gamma$ é uma citocina pró-inflamatória que favorece a fagocitose e a atividade microbicida dos macrófagos, pois aumenta a síntese de intermediários reativos do nitrogênio e oxigênio, além de estimular a produção de IL-12 (ROMANI; PUCCETTI; BISTONI, 1997). Ao contrário, IL-10 e TGF- $\beta$ (Th3) controlam a produção desta citocina inibindo sua 
produção pelos macrófagos, pois reprimem a transcrição da subunidade p40, limitando a quantidade de IL-12p70 (VECCHIO et al., 2007).

As diferenças entre $B$. pertussis e $B$. parapertussis quanto à estrutura da molécula de LPS e expressão da PT que inibe a função da proteína Gai podem ser características importantes para a geração de IL-12 quando os macrófagos são infectados com estas bactérias.

\subsection{A Bordetella e a resposta imune do hospedeiro}

Ao entrar no trato respiratório, a $B$. pertussis se liga às células epiteliais ciliadas e os macrófagos alveolares e as DCs, células da imunidade inata do hospedeiro, são as primeiras a reconhecer e iniciar a resposta imune local contra esta bactéria. Posteriormente, os linfócitos T e B que são células efetoras do sistema imune adquirido medeiam à eliminação da bactéria através do desenvolvimento da imunidade específica (GOUW et al., 2011). Neste processo, foi demonstrado que a infecção por $B$. pertussis promove o desenvolvimento da resposta Th1 devido à produção de grande quantidade de IFN- $\gamma$ (MILLS, 2001). Além disso, Higgins et al. (2006) mostraram que as células Th17 são importantes para a imunidade celular contra essa bactéria.

O sistema de secreção do tipo III (TTSS), um aparato especializado que permite as bactérias Gram-negativas injetarem proteínas efetoras diretamente dentro do citosol de células eucariotas, pode facilitar a colonização e sobrevivência de $B$. pertussis por promover a adesão bacteriana, por inibir a resposta inflamatória local, a indução da resposta antígeno específica Th1, Th17 e a produção de anticorpos que permitem a eliminação da bactéria do trato respiratório (FENNELLY et al., 2008).

Outro fator de virulência, a FHA de B. pertussis pode suprimir a resposta Th1 por estimular a produção de IL-10 por DCs inibindo assim a produção de IL-12. Isto direciona a diferenciação de células T naive em células efetoras T regulatórias (Treg) (MCGUIRK et al., 2002). Além da FHA, a ação sinérgica da ACT com o LPS de B. pertussis também estimula os macrófagos e DCs a produzirem IL-10 inibindo a produção de IL-12 (ROSS et al., 2004). Em B. bronchiseptica, a síntese desta citocina anti-inflamatória parece associada ao TTSS III (PILIONE; HARVILL, 2006). Nagamatsu et al. (2009) demonstraram que BopN, molécula efetora translocada para o interior da célula hospedeira pelo TTSS III, seria uma das 
responsáveis pela indução da produção de IL-10 por inibir ERK1/2 MAPKs evitando assim a resposta inflamatória.

Em infecção com $B$. parapertussis, a redução do número de bactérias no pulmão está associada ao acúmulo de linfócitos $\mathrm{T} \mathrm{CD}^{+}$e a produção de IFN- $\gamma$ por estas células. Contudo, a resposta mediada por IFN- $\gamma$ é atrasada devido à produção de IL-10 que reduz o acúmulo de leucócitos no local e atrasa a eliminação de B. parapertussis do pulmão. Isto é mais uma comprovação de que nesta infecção a presença de IL-10 limita a produção de IFN$\gamma$, permitindo que a bactéria persista no trato respiratório do hospedeiro. Dessa maneira, a produção de IL-10 pode ser uma estratégia usada por esta bactéria para evadir-se da resposta imune (WOLFE; BUBOLTZ; HARVILL, 2010).

Analisando os dados da literatura observamos que durante a resposta imune desenvolvida pela infecção com B. pertussis pode haver a produção de IL-12 pelas APCs que leva a polarização da resposta Th1, enquanto a IL-1 $\beta$ e a IL-23 dirigem a diferenciação de células Th17. Entretanto, no início da infecção, a resposta mediada por linfócitos Th1 e Th17 é suprimida devido à produção de IL-10 pelas células do sistema imune inato em resposta a FHA, ACT ou o TTSS e consequentemente pelas células T regulatórias (Treg) geradas. As toxinas bacterianas, especialmente LPS e TCT induzem a produção de óxido nítrico (NO) e citocinas pró-inflamatórias como IL-1 e TNF- $\alpha$. A IL-17 sintetizada por células Th17 promove a produção de uma quimiocina denominada proteína inflamatória de macrófagos 2 (MIP-2) e a ativação e o recrutamento de neutrófilos. Assim, a B. pertussis é fagocitada por neutrófilos e macrófagos (HIGGS et al., 2012).

O NO produzido por macrófagos é um importante agente tóxico para o controle de uma variedade de patógenos. E é sintetizado por ação da enzima óxido nítrico sintase induzida (iNOS ou NOS2) a partir do aminoácido L-arginina (TRIPATHI et al., 2007). O trabalho de ROSETTI (2009) realizado no laboratório de Bacteriologia do Instituto Butantan utilizando macrófagos derivados de medula óssea murina estimulados in vitro com Ag solúvel de $B$. pertussis ou infectados ativamente teve como objetivo investigar o envolvimento de alguns fatores na regulação de NO e mostrou que TGF- $\beta$ e a arginase, enzima que assim como a iNOS utiliza o substrato L-arginina, contribuem para a síntese de NO durante a ativação dos macrófagos. E que este mecanismo é dependente de TLR-4 (Dados não publicados).

A importância em estudar os mecanismos de controle da IL-12 se dá também pelo fato da vacina celular incluir PAMPs, como resíduos de LPS, que ativa a produção desta citocina além de IL-1, IL-6 e IL-23 por macrófagos e DCs. Estas citocinas pró-inflamatórias induzem 
a resposta Th1 e Th17. Em contraste, a vacina acelular inclui o hidróxido de alumínio como adjuvante que estimula a produção de IL-1 e consequentemente células Th17. Os linfócitos Th2 também são induzidos e auxiliam os linfócitos B a secretarem anticorpos que neutralizam toxinas e previnem a adesão de B. pertussis às células do trato respiratório (HIGGS et al., 2012). As células B também são necessárias para a eliminação de $B$. parapertussis e $B$. bronchiseptica do trato respiratório de camundongos (KIRIMANJESWARA; MANN; HARVILL, 2003).

Segundo Mahon et al. (1996), a adição exógena de IL-12 a vacina acelular induziu a mudança na polarização de uma resposta Th2 para Th1.

Apesar de B. pertussis ser considerada um patógeno intracelular facultativo, os mecanismos pelos quais a ativação dos macrófagos resulta na morte desse tipo de patógeno ainda não estão completamente esclarecidos (CANTHABOO et al., 2002). Foi demonstrado que essa bactéria opsonizada pode ser fagocitada via receptor Fc para IgA, Fc $\alpha$ RI (CD89), e

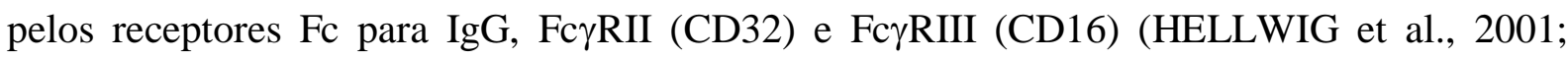
RODRIGUEZ et al., 2001). No entanto, B. pertussis pode sobreviver intracelularmente dentro de macrófagos humanos na ausência de anticorpos opsonizantes (LAMBERTI et al., 2010).

A presença de $\operatorname{IgA}$ parece ser essencial para o controle de B. bronchiseptica na cavidade nasal e traqueia, mas não nos pulmões (WOLFE et al., 2007). Enquanto que a eliminação de $B$. parapertussis da traqueia e pulmões requer anticorpos $\operatorname{IgG}$ e $\operatorname{IgM}$, mas não IgA, além de linfócitos T e leucócitos polimorfonucleares. Porém, os receptores FcR não são necessários para a sua redução, diferentemente do observado com B. pertussis, embora possam contribuir para a eliminação da bactéria. Isto indica que a resposta imune de $B$. pertussis e B. parapertussis não é idêntica (WOLFE; KIRIMANJESWARA; HARVILL, 2005).

Estudos com B. pertussis tem recebido maior atenção da comunidade científica, diferentemente do observado com $B$. parapertussis que também pode ser responsável por uma grande porcentagem dos casos dessa doença. Portanto, o estudo da resposta imune gerada pelo hospedeiro contra B. parapertussis também é de alta relevância (WOLFE; KIRIMANJESWARA; HARVILL, 2005).

O fato da proteção contra $B$. pertussis estar relacionada com a produção de IFN- $\gamma$ por linfócitos Th1 e a IL-12 ser uma importante citocina que promove a ligação entre a imunidade inata e adaptativa, direcionando a diferenciação de células $\mathrm{T} \mathrm{CD}^{+}$naive em células Th1 efetoras, além do seu uso como adjuvante em vacinas ser de grande interesse mostra que 
outros estudos são necessários para elucidar os mecanismos de sinalização envolvidos na regulação da produção desta citocina. Soma-se a isso, o fato de vacinas produzidas contra $B$. pertussis não protegerem conta $B$. parapertussis e não haver dados que descrevam a contribuição da IL-12 na resposta imune principalmente durante a infecção com esta última bactéria. Essas duas espécies de Bordetella apresentam ainda diferenças na estrutura da molécula de LPS e na expressão da PT. Logo, estes aspectos reforçam a importância de investigarmos se essas bactérias modulam diferentemente a síntese de IL-12. 


\section{OBJETIVO}

Investigar a contribuição de mediadores imunes e vias de sinalização que controlam a síntese de IL-12 em macrófagos derivados de medula óssea murina ( $\mathrm{M} \phi \mathrm{DM})$ ativados in vitro com B. pertussis e B. parapertussis 


\section{MATERIAL E MÉTODOS}

\subsection{Bactérias}

\subsubsection{Cultivo de B. pertussis e B. parapertussis}

Para a infecção in vitro dos M $\phi \mathrm{DM}$, utilizamos a cepa 18323 de $B$. pertussis (ATCC 9797) e a cepa de B. parapertussis (ATCC 15311) adquirida da coleção de cultura bacteriana do Instituto Adolfo Lutz.

As bactérias foram cultivadas em estufa bacteriológica a $37^{\circ} \mathrm{C}$ em placas de Petri contendo meio Bordet-Gengou (BG) suplementado com $25 \%$ de sangue de carneiro, cedidas pelo setor de meios de cultura do Instituto Butantan.

\subsubsection{Obtenção dos componentes solúveis (antígeno solúvel) de B. pertussis ou B. parapertussis}

Após o cultivo em meio BG, as bactérias foram expandidas em meio líquido Stainer \& Scholte (SS) a $37{ }^{\circ} \mathrm{C}$ sob agitação de $200 \mathrm{rpm}$ por 48 horas. Em seguida, as bactérias foram centrifugadas (Himac 21E, Ontário, Canadá) a 12250 g, 10 minutos, $4{ }^{\circ} \mathrm{C}$ sendo o sobrenadante e o sedimento separados. O sedimento contendo as bactérias foi inativado em tampão de sonicação, composto por Tris base $(50 \mathrm{mM})$ e cloreto de sódio $(150 \mathrm{mM}) \mathrm{pH} 8,0$, por 120 minutos a $56{ }^{\circ} \mathrm{C}$ na presença de $30 \mu \mathrm{g} / \mathrm{mL}$ de gentamicina. Posteriormente as bactérias foram rompidas por sonicação (Bandelin Sonopuls ultrasonic homogenizer HD2270, Berlim, Alemanha) a $4{ }^{\circ} \mathrm{C}$ por três ciclos de cinco minutos. O material obtido foi centrifugado a $12250 \mathrm{~g}, 4^{\circ} \mathrm{C}$ para separação da fração solúvel dos restos celulares. A parte solúvel obtida foi dialisada utilizando uma membrana com peso molecular de corte (cut off) de $12000 \mathrm{Da}$ e posteriormente foi realizado gel SDS-Page $12 \%$ para verificar o perfil proteico. Finalmente, a parte solúvel foi filtrada em membrana de 0,22 $\mu \mathrm{m}$ (Merck Millipore, Billerica., MA, USA), aliquotada e estocada a $-20{ }^{\circ} \mathrm{C}$ na presença de inibidor de protease PMSF $(1 \mathrm{mM})$ até o momento de uso.

A dosagem de proteína nas amostras foi realizada utilizando o kit BCA Pierce (Thermo Fisher Scientific, Rockford., IL, USA). 


\subsubsection{Dosagem de endotoxina do antígeno solúvel de B. pertussis ou B. parapertussis}

A faixa de endotoxina presente nas amostras de antígeno solúvel de $B$. pertussis ou $B$. parapertussis foi mensurada pelo teste de Limulus Amebocyte Lysate (LAL) kit da Lonza (Basel, Suíça), de acordo com as instruções do fabricante (sensibilidade de 0,125 UE/mL). Esse teste foi realizado pelo Serviço de Controle de Qualidade do Instituto Butantan. Observamos que ambas as amostras apresentaram os mesmos níveis de endotoxina que variou entre 1,25 a 12,5 UE/mL, sendo o meio de cultura inferior ao limite de detecção do método de $1,25 \mathrm{UE} / \mathrm{mL}$.

\subsubsection{Obtenção de bactérias viáveis para infecção in vitro}

Como a cinética de crescimento das duas bactérias difere utilizamos bactérias cultivadas em meio ágar BG por 24 (B. parapertussis) ou 72h (B. pertussis) que corresponde a fase exponencial de crescimento destas bactérias. Posteriormente, as bactérias foram lavadas com meio RPMI 1640 (Gibco Invitrogen Corporation, São Paulo., SP, Brasil). A densidade óptica (DO) foi lida a $530 \mathrm{~nm}$ (Spectronic ${ }^{\circledR} 20$ Genesys $^{\mathrm{TM}}$, Thermo Electron, Waltham., MA, USA) e a concentração bacteriana ajustada para $\mathrm{DO}=1$, o que corresponde a aproximadamente $10^{8}-10^{9}$ bactérias $/ \mathrm{mL}$. Antes dos experimentos, todas as amostras foram testadas quanto a não contaminação com outras bactérias usando a coloração de Gram.

\subsection{Animais}

Foram utilizados macrófagos derivados de medula óssea de camundongos C57BL/6 e C3H/HeJ (mutante no gene Tlr4), C57BL/6 MyD88 ${ }^{-/-}$fêmeas com 6-8 semanas de idade aprovados pela Comissão de Ética no uso de animais do Instituto Butantan, protocolo $\mathrm{n}^{\circ}$ 535/08. Estes animais foram obtidos da Faculdade de Medicina ou Medicina Veterinária ou Instituto de Ciências Biológicas da USP e mantidos no biotério sob condições apropriadas, utilizando micro isoladores para minimizar a contaminação com microrganismos.

\subsection{Macrófagos medulares}




\subsubsection{Cultivo de células L929 para obtenção do fator de crescimento M-CSF}

As células L929 adquiridas do Instituto Adolfo Lutz foram cultivadas (1x10 $/ \mathrm{mL}) \mathrm{em}$ meio RPMI 1640 contendo 10\% de soro fetal bovino (Cripion, Andradina,.SP, Brasil), 50 U/mL de penicilina (Sigma, St. Louis., MO, USA) e $50 \mu \mathrm{g} / \mathrm{mL}$ de estreptomicina (Interlab, São Paulo,. SP, Brasil), sendo mantidas por sete dias a $37^{\circ} \mathrm{C}, 5 \%$ de $\mathrm{CO}_{2}$. Após este período o sobrenadante a ser utilizado para cultivo e diferenciação das células da medula óssea foi centrifugado (Eppendorf Centrifuge 5804R, Hamburgo, Alemanha) por 10 minutos a $259 \mathrm{~g}$, filtrado em membrana de 0,22 $\mu \mathrm{m}$ (Merck Millipore) estocado a $-20{ }^{\circ} \mathrm{C}$ até o momento do uso.

O sobrenadante de células fibroblásticas murinas L929 contém o fator estimulador de colônias de macrófagos M-CSF, fornecendo uma alternativa para a diferenciação e proliferação de células progenitoras da medula óssea em macrófagos maduros in vitro (BOLTZ-NITULESCU et al., 1987; GERSUK; HIRAOKA; MARR, 2004; SURESH; SODHI, 1991).

\subsubsection{Obtenção e cultivo de macrófagos derivados de medula óssea murina (M $\phi D M)$}

Os macrófagos derivados de medula óssea foram obtidos a partir do fêmur e da tíbia dos camundongos C57BL/6, C3H/HeJ e MyD88 ${ }^{-/}$. Após a obtenção das células, estas foram centrifugadas por 10 minutos, $4{ }^{\circ} \mathrm{C}$ a $259 \mathrm{~g}$, o sobrenadante foi desprezado e sobre o sedimento foi adicionado o tampão de lise de hemácias (ACK) composto por 0,15 M de cloreto de amônio $\left(\mathrm{NH}_{4} \mathrm{Cl}\right), 1 \mathrm{mM}$ de bicarbonato de potássio $\left(\mathrm{KHCO}_{3}\right)$ e $0,1 \mathrm{M}$ de EDTA dissódico ( $\left.\mathrm{Na}_{2} \mathrm{EDTA}\right)$. As células foram então incubadas a temperatura ambiente por 5 minutos e em seguida lavadas duas vezes com PBS pH 7,2. O sobrenadante foi descartado e o sedimento contendo as células foi ressuspendido em volume conhecido de meio RPMI 1640 completo suplementado com $10 \%$ de soro fetal bovino inativado, 25-30\% sobrenadante de célula L929, penicilina e estreptomicina $(50 \mathrm{U} / \mathrm{mL}$ e $50 \mu \mathrm{g} / \mathrm{mL}$, respectivamente). A concentração celular foi ajustada para $1,5 \times 10 \% \mathrm{~mL}$, sendo colocado $0,5 \mathrm{~mL} /$ poço na placa de cultura celular de 24 poços (Costar, Cambridge, MA., USA). Nos ensaios de FACS para a analise fenotípica dos macrófagos utilizamos $2 \mathrm{~mL} /$ poço na placa de 6 poços (TPP, Trasadingen, Suíça). Posteriormente, estas células foram cultivadas a $37{ }^{\circ} \mathrm{C}, 5 \%$ de $\mathrm{CO}_{2}$. No 
terceiro e no quinto dia de cultura as células foram realimentadas com meio novo e quando necessário foram expandidas para novas placas de cultura celular.

No sétimo dia as células já diferenciadas foram lavadas com PBS pH 7,2, para a remoção das células não aderentes, e cultivadas em meio RPMI completo na ausência de sobrenadante de L929 para iniciar o experimento.

\subsubsection{Análise do fenótipo de macrófagos derivados de medula óssea murina (MфDM)}

A diferenciação das células progenitoras da medula óssea em macrófagos maduros foi confirmada pela separação de células ativadas por fluorescência (FACS) analisando a expressão da molécula F4/80 (marcador de macrófagos) na superfície das células.

Para isto as células foram coletadas dos poços da placa com o auxilio do cell scraper, centrifugadas por 10 minutos, $4{ }^{\circ} \mathrm{C}$ a $259 \mathrm{~g}$. Em seguida foi feito o bloqueio com um pool de soro por $1 \mathrm{~h}$ a $4{ }^{\circ} \mathrm{C}$ (SCHMEISSER et al., 2001), lavadas e em seguida incubadas por $1 \mathrm{~h}$ a $4{ }^{\circ} \mathrm{C}$ na ausência de luz com o anticorpo específico, anti F4/80 PE $(0,5 \mu \mathrm{g} / \mathrm{mL})$ ou anti B220 (CD45R) FITC $(0,25 \mu \mathrm{g} / \mathrm{mL})$ ou anti CD3 AlexaFluor $647(0,5 \mu \mathrm{g} / \mathrm{mL})$ (Invitrogen, Carlsband, CA., USA) diluídos em PBS pH 7,2 suplementado com 2\% de soro fetal bovino inativado. Após marcação as células foram fixadas com $2 \%$ de paraformaldeído e lidas usando citômetro de fluxo (BD Biosciences FACSCanto, São José, CA., USA) para determinar a porcentagem de células positivas para F4/80. Foram lidos 10.000 eventos.

\subsubsection{Ativação e infecção dos macrófagos}

Os macrófagos medulares murinos foram estimulados com $30 \mu \mathrm{g} / \mathrm{mL}$ de antígeno solúvel de Bordetella pertussis ou Bordetella parapertussis, concentração previamente estabelecida no laboratório, ou LPS de Escherichia coli O111:B4 (2 $\mu \mathrm{g} / \mathrm{mL})$ utilizado como controle positivo das reações.

Em alguns ensaios, os macrófagos foram tratados com inibidor de NFאB (BAY 117082, $10 \mu \mathrm{M}$, Sigma) ou inibidores de p38 (SB202190, $10 \mu \mathrm{M}$, Calbiochem EMD Millipore Billerica, MA., USA) e ERK 1/2 MAPK (PD98059, $20 \mu \mathrm{M}$, Calbiochem) ou inibidor de PI3K (Vortimanina, $100 \mathrm{nM}$, Sigma) ou $10 \mu \mathrm{g} / \mathrm{mL}$ do anticorpo específico anti-TNF- $\alpha$ (R\&D Systems, Minneapolis, MN., USA) por 1h antes da estimulação com antígeno solúvel de $B$. pertussis ou B. parapertussis $(30 \mu \mathrm{g} / \mathrm{mL})$. A PT $(0,5 \mu \mathrm{g} / \mathrm{mL}$, Sigma) foi adicionada $1 \mathrm{~h}$ antes 
somente da estimulação com Ag de B. parapertussis $(30 \mu \mathrm{g} / \mathrm{mL})$. Após o cultivo por 20 horas o sobrenadante das culturas foi obtido e posteriormente analisado quanto a presença de IL12p40 ou IL-12p70.

Em outras situações foram infectados por $2 \mathrm{~h}$ com B. pertussis ou B. parapertussis $(\mathrm{DO}=1)$. Após este período as bactérias extracelulares foram removidas pela incubação das células infectadas com os antibióticos gentamicina $(30 \mu \mathrm{g} / \mathrm{ml})$ e polimixina B $(30 \mu \mathrm{g} / \mathrm{ml})$ por 45 minutos. O antibiótico foi removido por três lavagens com PBS pH 7,2. Em seguida as células foram cultivadas em meio RPMI completo sem antibiótico e sem M-CSF.

Em alguns experimentos para a dosagem de IL-12p70, as culturas de macrófagos foram tratadas com IFN- $\gamma(2 \mathrm{ng} / \mathrm{mL})$ e estimuladas com antígeno solúvel de $B$. pertussis ou $B$. parapertussis.

\subsection{Dosagem de citocinas}

\subsubsection{Dosagem de IL-12 e TNF- $\alpha$}

Para a dosagem de IL-12p40 e TNF- $\alpha$ foi utilizado o Kit de ELISA (eBioscience, San Diego, CA., USA). E para dosagem de IL-12p70 foi utilizado o kit de ELISA da OptEIA (BD PharMingen, Franklin Lakes, NJ., USA).

A subunidade p40 também pode se associar a subunidade p19 constituindo a IL-23, em função disto os anticorpos usados para o ELISA detectam IL-12/IL-23p40 e foi denominado IL-12p40, como é usual na literatura.

Brevemente, as placas foram sensibilizadas utilizando o anticorpo de captura em tampão apropriado na diluição 1:250 com incubação por 18 horas a $4{ }^{\circ} \mathrm{C}$, posteriormente as placas foram lavadas e bloqueadas com diluente apropriado por $1 \mathrm{~h}$ sendo lavadas novamente. Em seguida foi adicionado as amostras diluídas ou não dependendo do ensaio utilizado. As amostras foram novamente incubadas 18 horas/ $4{ }^{\circ} \mathrm{C}$. Após esse período o anticorpo de detecção foi diluído 1:250 em tampão apropriado e as placas novamente incubadas por 1h a temperatura ambiente. Posteriormente. As placas foram novamente lavadas para remover o anticorpo livre e em seguida adicionou-se avidina marcada com peroxidase com posterior incubação por 30 minutos a temperatura ambiente. Após nova lavagem o TMB (substrato) foi adicionado e a reação interrompida com $\mathrm{H}_{2} \mathrm{SO}_{4}(2 \mathrm{~N})$ e lida a $450 \mathrm{~nm}$ em leitor de microplacas Multiskan EX Primary EIA (Labsystems, Helsinki, Finlândia). 
As concentrações de IL-12 e TNF- $\alpha$ foram determinadas a partir de curvas padrões obtidas com o recombinante específico para cada uma dessas citocinas.

\subsection{Análise estatística}

Os níveis de citocinas foram analisados pelo teste ANOVA para comparações entre grupos experimentais. E para comparação entre dois grupos experimentais foi realizado o teste t Student. Foi considerado estatisticamente significativo valores de $p<0,05$ utilizando o programa estatístico Prisma 5.0 (GraphPad). 


\section{RESULTADOS}

\subsection{Caracterização do fenótipo de $M \phi D M$ diferenciados in vitro na presença de M-CSF}

Confirmamos por citometria de fluxo o fenótipo das células obtidas da medula óssea murina após sete dias de diferenciação analisando a porcentagem de células positivas para o marcador de macrófagos, F4/80, utilizando anticorpo específico. Observamos que 99\% das células cultivadas na presença de M-CSF, proveniente do sobrenadante de células L929, foram positivas para F4/80 e negativas para os marcadores típicos de linfócitos T e B, CD3 e B220 (CD45R) respectivamente (Figura 5). Isto indica que a população de células diferenciadas são macrófagos, não havendo outros tipos celulares na cultura.

Figura 5 - Análise por FACS da expressão da molécula F4/80 na superfície de $M \phi D M$ diferenciados in vitro.

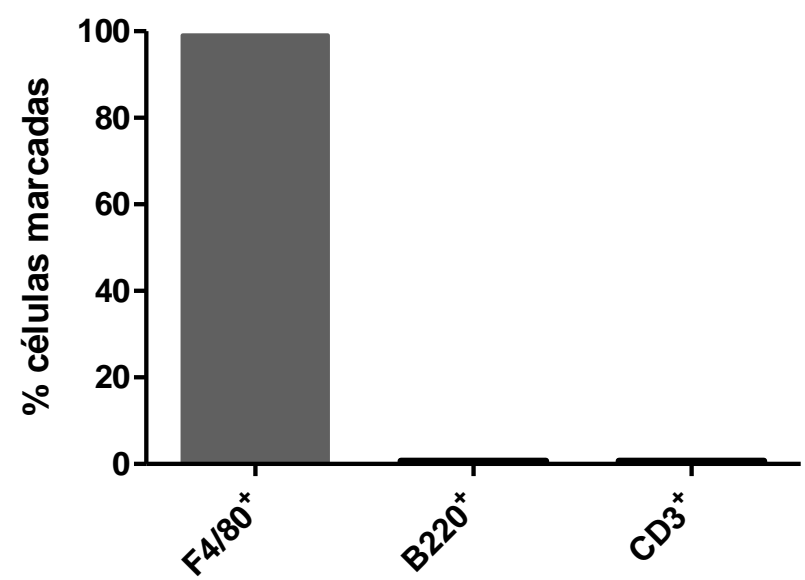

Os M $\phi$ DM ( $3 \times 10^{6} /$ poço) de C57BL/6 foram cultivados em meio RPMI 1640 completo contendo MCSF conforme descrito em material e métodos. As células aderentes foram obtidas após 7 dias e analisadas por FACS para confirmação do fenótipo. 
4.2 Comparação entre B. pertussis e B. parapertussis quanto a capacidade de estimular a produção de IL-12p40

Nossos resultados mostraram que os componentes solúveis (antígeno solúvel, Ag) obtidas do lisado de B. pertussis e B. parapertussis (Figura 6A) assim como a infecção ativa (Figura 6B) induziram a síntese de níveis semelhantes e significativos de IL-12p40 pelos M $\phi D M$, não havendo diferença significativa entre as duas espécies de Bordetella, demonstrando então que independente da natureza do estímulo a resposta foi similar entre as duas bactérias.

$\mathrm{Na}$ infecção ativa foi detectado respectivamente 849 pg/mL e 699 pg/mL de IL-12p40 para B. pertussis e B. parapertussis. Enquanto os M $\phi D M$ estimulados com os Ags solúveis de B. pertussis e B. parapertussis produziram $789 \mathrm{pg} / \mathrm{mL}$ e $770 \mathrm{pg} / \mathrm{mL}$ respectivamente. Os M $\phi D M$ ativados com LPS de E. coli usado como controle positivo também produziram níveis elevados desta citocina. 
Figura 6 - Comparação entre $B$. pertussis e $B$. parapertussis quanto à capacidade de ativar M $\phi D M$ a sintetizar IL-12p40

A

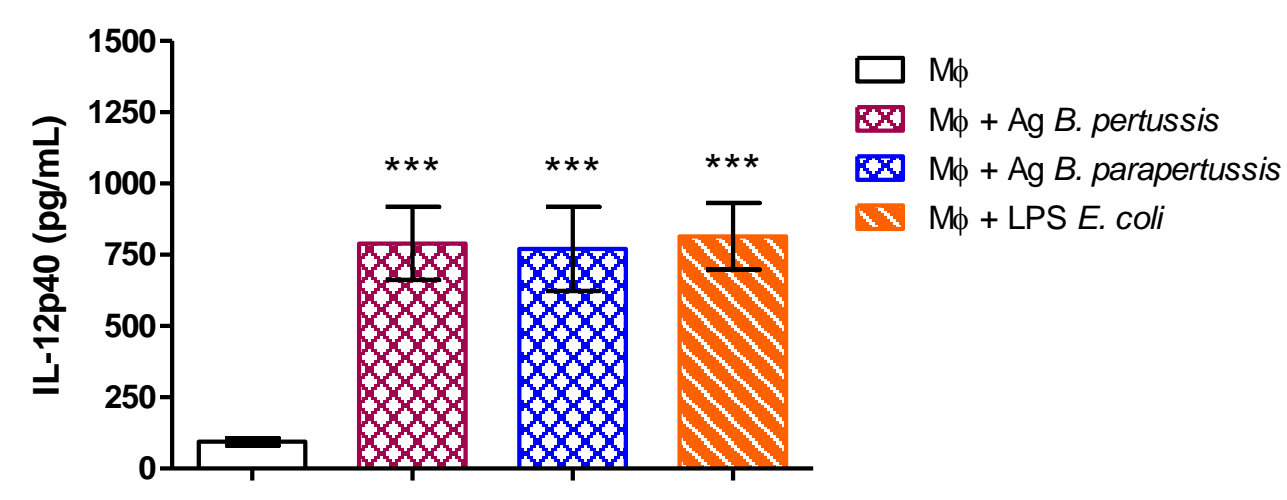

B

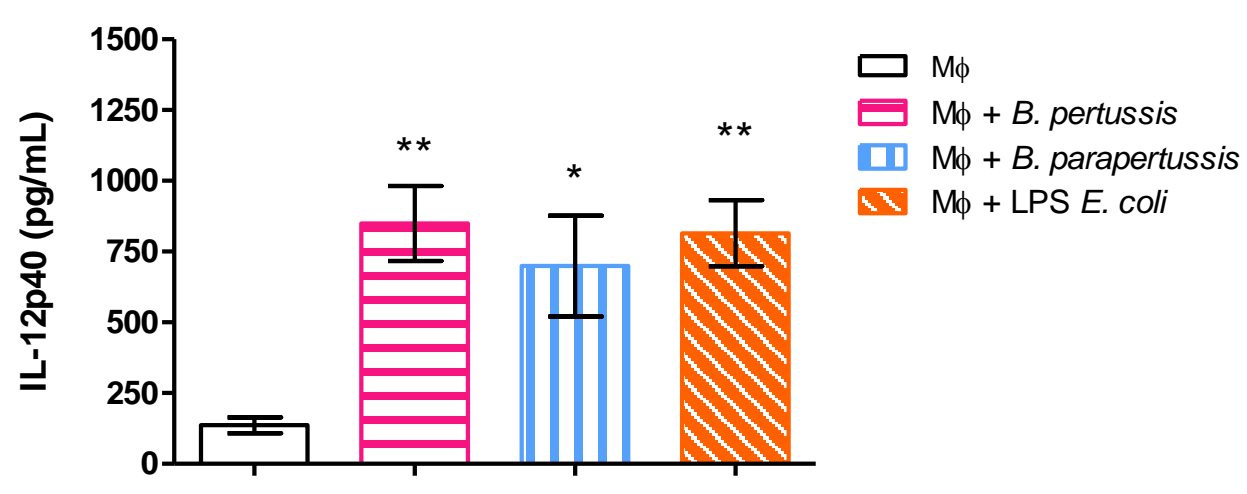

Os M MDM (7,5x10\%/poço) de C57BL/6 foram estimulados com $30 \mu \mathrm{g} / \mathrm{mL}(\mathrm{A})$ ou infectados (DO=1) (B) com B. pertussis e B. parapertussis. Após 20 horas o sobrenadante foi obtido para a dosagem de IL-12p40. Os resultados representam a média com o erro padrão (SEM) de oito ensaios independentes, realizados em duplicata. $* * * \mathrm{p}<0,0001 ; * * \mathrm{p}<0,01 ; * \mathrm{p}<0,05$ em relação ao grupo não estimulado $(\mathrm{M} \phi)$. 


\subsection{Análise da contribuição do TNF- $\alpha$ na síntese de IL-12p40}

\subsubsection{Produção de TNF- $\alpha$ após a ativação in vitro dos $M \phi D M$ com antígeno solúvel ou infectados com B. pertussis e B. parapertussis}

A figura 7A mostra que os M $\phi D M$ estimulados com os componentes solúveis de $B$. pertussis e $B$. parapertussis induziram significativamente a produção de TNF- $\alpha$. Em seguida, considerando que estas duas espécies de Bordetella diferem na estrutura da molécula de LPS e que $B$. parapertussis não expressa a toxina pertussis, comparamos se a infecção ativa com estas bactérias poderia modular diferentemente a produção de TNF- $\alpha$. Nossos resultados mostraram que a infecção com B. pertussis e B. parapertussis estimulou a produção de níveis significativos de TNF- $\alpha$ pelos $\mathrm{M} \phi \mathrm{DM}$, sendo que $B$. parapertussis induziu níveis superiores desta citocina quando comparado com B. pertussis, diferindo significativamente (Figura 7B). 
Figura 7 - Produção de TNF- $\alpha$ por $\mathrm{M} \phi D M$ de camundongos C57BL/6 ativados in vitro por B. pertussis e B. parapertussis

A

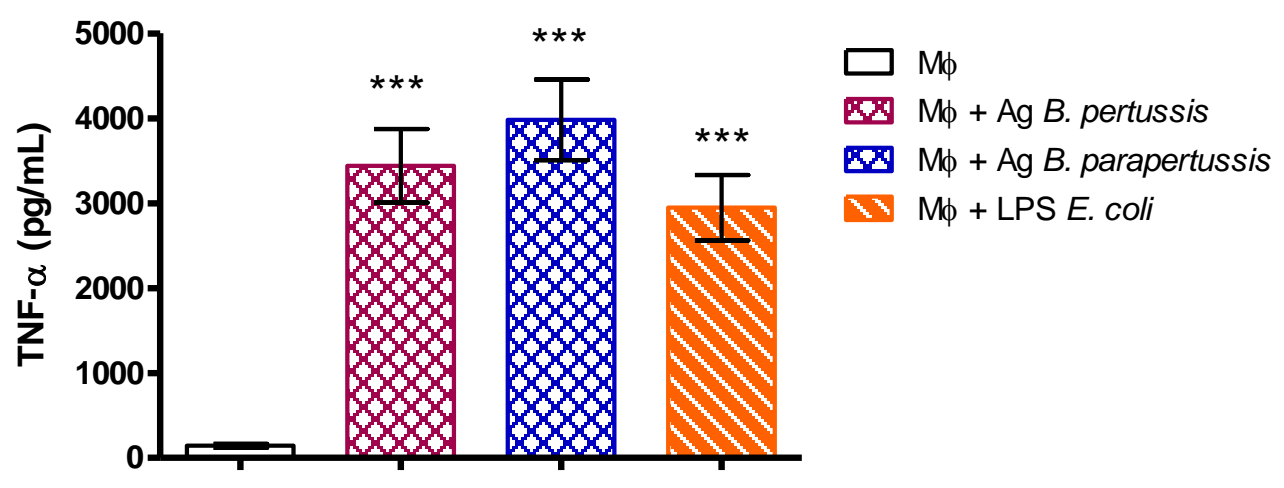

B

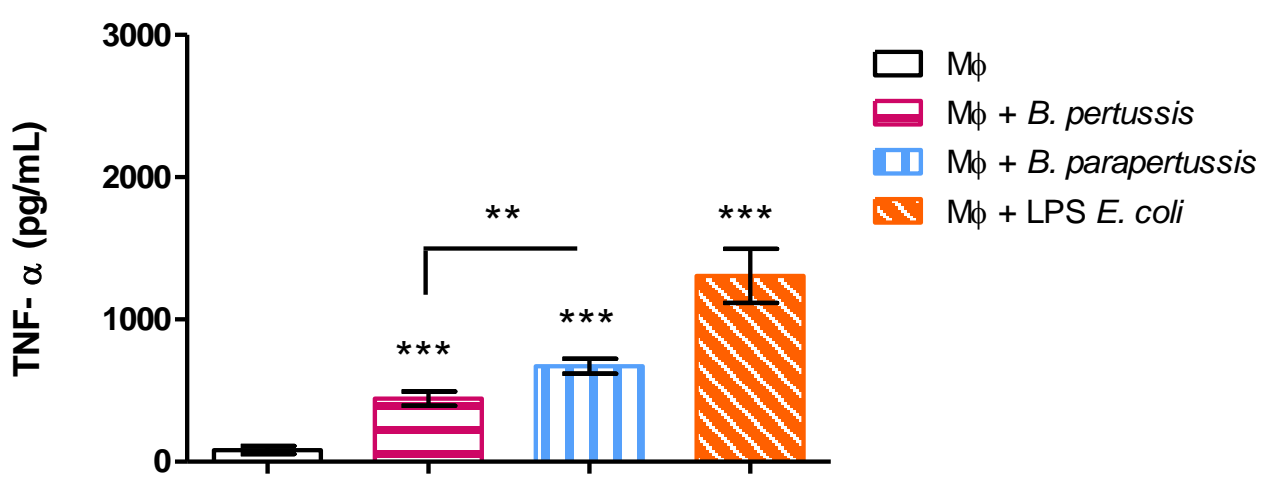

Os $\mathrm{M} \phi \mathrm{DM}\left(7,5 \times 10^{5} /\right.$ poço) de C57BL/6 foram estimulados com $30 \mu \mathrm{g} / \mathrm{mL}$ (A) ou infectados (DO=1) (B) por B. pertussis e B. parapertussis. Após 20 horas o sobrenadante foi obtido para a dosagem de TNF- $\alpha$. Os resultados representam a média com o erro padrão (SEM) de quatro ensaios independentes, realizados em duplicata. *** $\mathrm{p}<0,001$ em relação ao grupo não estimulado $(\mathrm{M} \phi)$; ** $\mathrm{p}<0,01$ comparação entre $B$. pertussis e B. parapertussis (B). 
4.3.2 Participação do TNF- $\alpha$ na regulação da síntese de IL-12p40 em M antígeno solúvel de B. pertussis e B. parapertussis

As figuras $8 \mathrm{~A}$ e $8 \mathrm{~B}$ mostram que o tratamento dos M $\phi \mathrm{DM}$ com anti-TNF- $\alpha$ por $1 \mathrm{~h}$ antes da estimulação com o lisado de B. pertussis e B. parapertussis reduziu significativamente a produção de IL-12p40 durante a ativação com as duas espécies de bactérias em comparação com as células que não foram tratadas com o anticorpo. Esta redução foi $57 \%$ e $55 \%$ para $B$. pertussis e B. parapertussis, respectivamente. Esses resultados indicam que a presença de TNF- $\alpha$ contribuiu para o aumento da síntese de IL12p40 durante a ativação de M $\phi D M$ com estas espécies de Bordetella. 
Figura 8 - Regulação da síntese de IL-12p40 por TNF- $\alpha$ em M $\phi D M$ estimulados com antígeno solúvel de $B$. pertussis e $B$. parapertussis
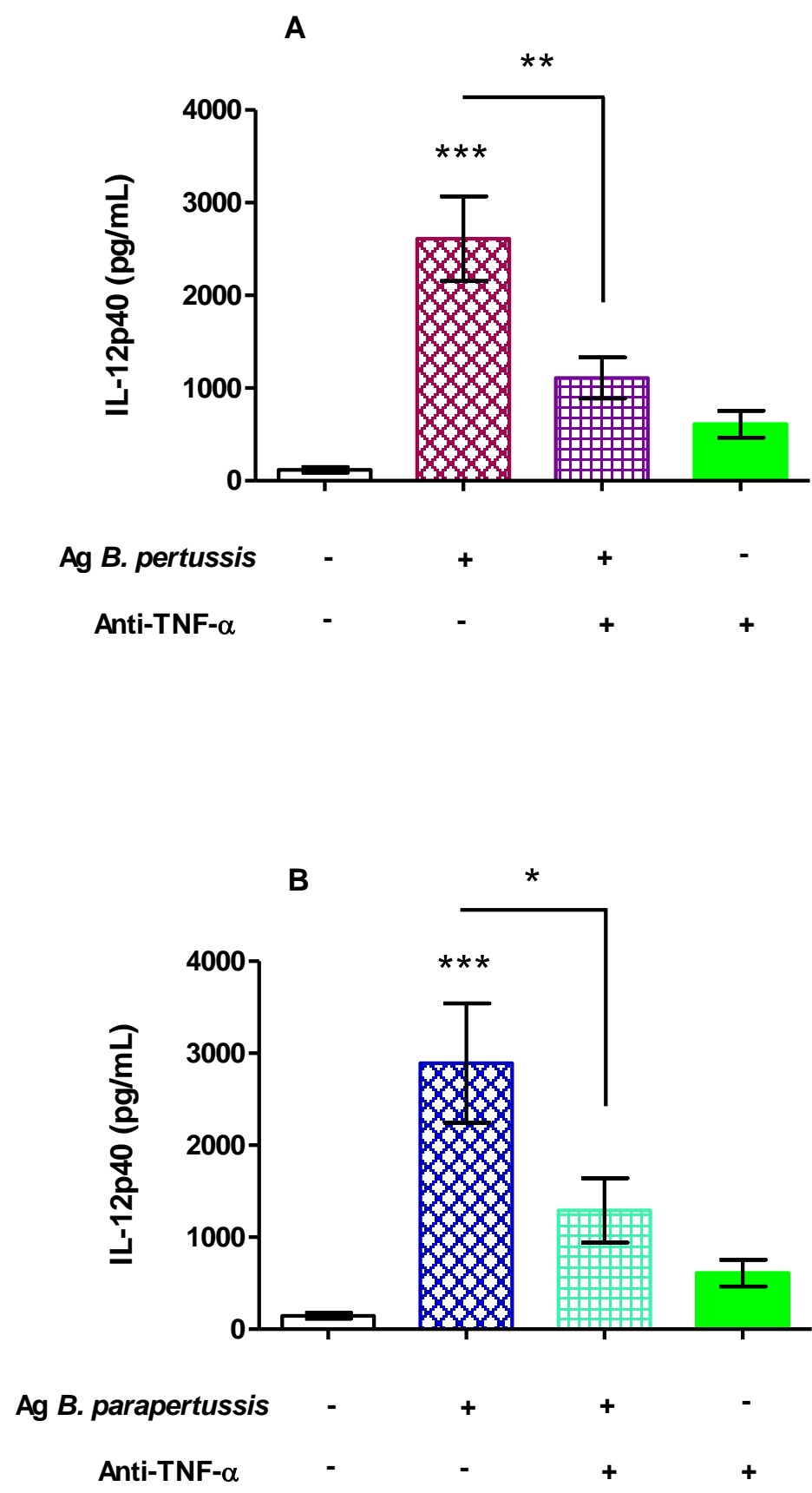

Os $\mathrm{M} \phi \mathrm{DM}\left(7,5 \times 10^{5} /\right.$ poço) de C57BL/6 foram pré-incubados ou não por $1 \mathrm{~h}$ com anti-TNF- $\alpha$ e posteriormente estimulados com Ag de B. pertussis (30 $\mu \mathrm{g} / \mathrm{mL}$ ) (A) ou Ag de B. parapertussis (30 $\mu \mathrm{g} / \mathrm{mL}$ ) (B). Após 20 horas o sobrenadante foi obtido para a dosagem de IL-12p40. Os resultados representam a média com o erro padrão (SEM) de três ensaios independentes, realizados em duplicata. *** $\mathrm{p}<0,0001$ na comparação entre o grupo não estimulado $(\mathrm{M} \phi)$ versus o grupo estimulado com $\mathrm{Ag} \mathrm{e}$ ** $\mathrm{p}<0,01 \mathrm{e}^{*} \mathrm{p}<0,05$ na comparação entre o grupo estimulado com Ag versus o grupo estimulado na presença de anti-TNF- $\alpha$. 


\subsection{Contribuição dos receptores Toll-like na síntese de IL-12p40 em M $\phi D M$ ativados com antígeno solúvel de $B$. pertussis e $B$. parapertussis}

\subsubsection{Análise da dependência de sinais emitidos pela molécula adaptadora MyD88}

Para investigar se a produção de IL-12p40 por M $\phi D M$ ativados com os componentes solúveis de $B$. pertussis e $B$. parapertussis dependeria da sinalização mediada pela molécula adaptadora MyD88 utilizamos macrófagos de camundongos deficientes nesta molécula $\left(\mathrm{MyD}^{-{ }^{-/}}{ }^{-}\right.$) comparando os dados obtidos com os camundongos selvagens (C57BL/6).

Nossos resultados mostram que os $\mathrm{M} \phi \mathrm{DM}$ de $\mathrm{MyD}^{-{ }^{-/}}$estimulados com Ag solúvel de $B$. pertussis não produziram níveis significativos de IL-12p40 quando comparado as células que não receberam o estímulo. Ao contrário, a ativação destas células com $\mathrm{Ag}$ de $B$. parapertussis induziu significativamente a produção desta citocina (Figura 9A). Entretanto,

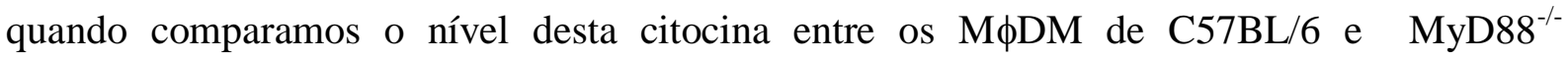
estimulados pelo Ag de B. pertussis (Figura 9B) ou B. parapertussis (Figura 9C) notamos que houve drástica redução na produção de IL-12p40. Esses resultados sugerem que a ativação dos $\mathrm{M} \phi \mathrm{DM}$ com os antígenos bacterianos de ambas as espécies de Bordetella requer sinais dependentes da molécula adaptadora MyD88 para a produção desta citocina. Entretanto, há indícios de que a ativação das células com o Ag de B. parapertussis diferentemente do $\mathrm{Ag}$ de B. pertussis pode ativar a via independente de MyD88 para a produção de IL-12p40. Isto indica que os TLRs são importantes para a síntese desta citocina. 
Figura 9 - Participação da molécula adaptadora MyD88 na regulação da síntese de IL12 p40 durante a ativação de $M \phi D M$ com antígeno de $B$. pertussis e $B$. parapertussis

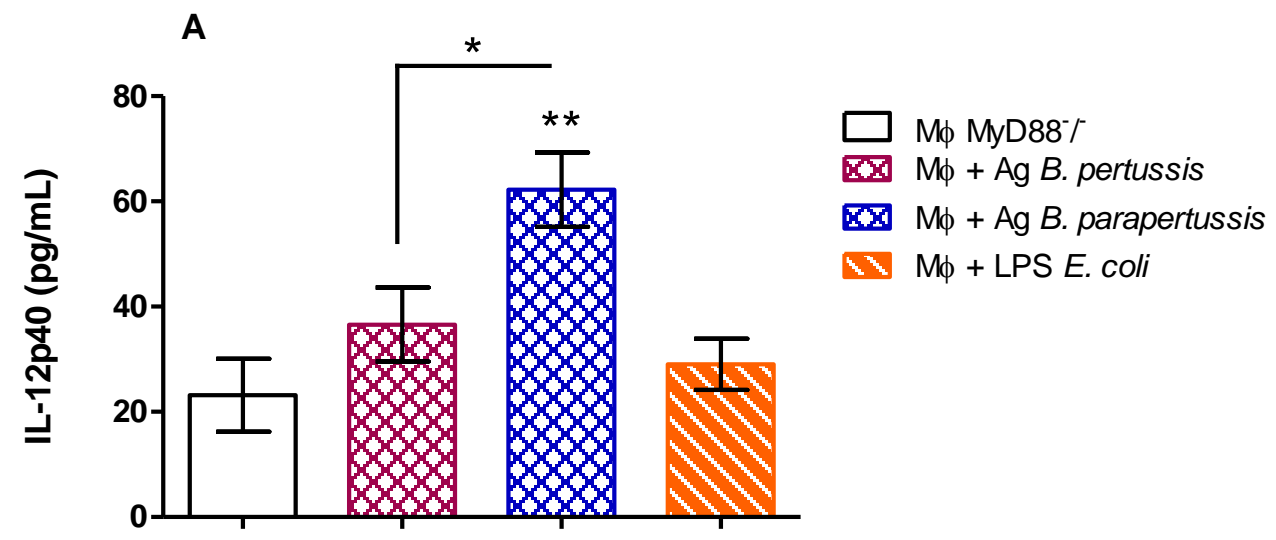

B

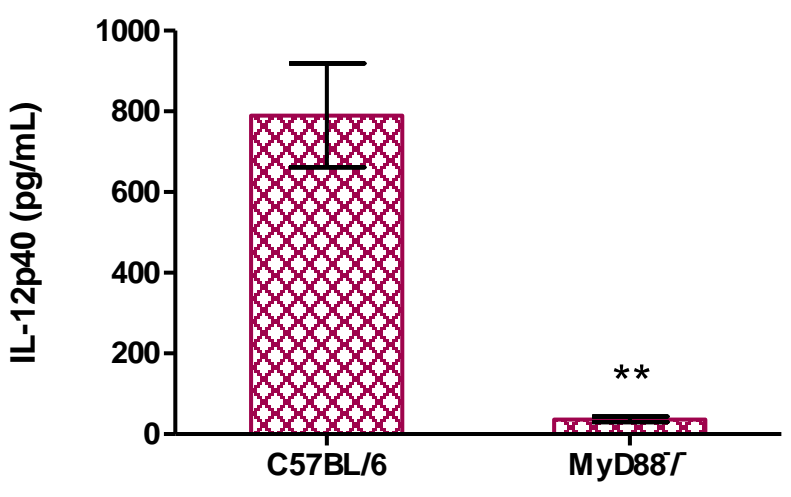

C

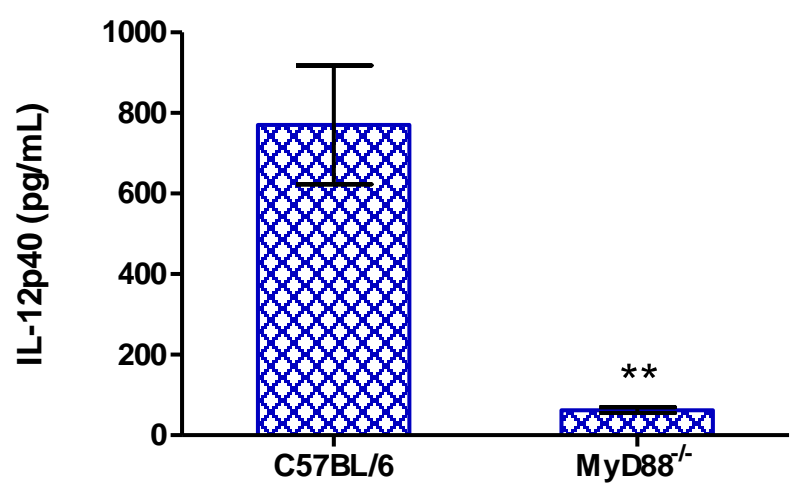

Os M $\phi \mathrm{DM}\left(7,5 \times 10^{5} /\right.$ poço) de MyD88 ${ }^{-/}$ou C57BL/6 foram ativados com Ag de B. pertussis (30 $\mu \mathrm{g} / \mathrm{mL}$ ) (A, B) ou Ag de B. parapertussis (30 $\mu \mathrm{g} / \mathrm{mL}$ ) (A, C). Após 20 horas o sobrenadante foi obtido para a dosagem de IL-12p40. Os resultados representam a média com o erro padrão (SEM) de três ensaios independentes, realizados em duplicata. $* * \mathrm{p}<0,01$ comparando o grupo não estimulado $(\mathrm{M} \phi)$ com o grupo estimulado com $\mathrm{Ag}$ de $B$. parapertussis e $* \mathrm{p}<0,05$ comparando os grupos ativados com $\mathrm{Ag}$ de $B$. pertussis e de B. parapertussis (A). ** $\mathrm{p}<0,01$ comparando os grupos de camundongos C57BL/6 e MyD88 $8^{-/}$ativados com os Ags (B, C). 


\subsubsection{Envolvimento do receptor TLR-4 para a síntese de IL-12p40 durante a ativação de} M $\phi D M$ com B. pertussis e B. parapertussis

Para estes ensaios foram utilizados macrófagos de camundongos da linhagem C3H/HeJ (Tlr4 \%) que são hiporresponsivos ao LPS devido a mutação no gene de TLR-4.

Nossos resultados mostraram que as células dos animais deficientes na sinalização via TLR-4 estimulados com Ag de B. pertussis produziram níveis significativos de IL-12p40, porém a infecção ativa não foi capaz de induzir significativamente a síntese desta citocina, sendo o nível próximo ao basal encontrado nas células não ativadas (M $\phi)$ (Figura 10A). No entanto, quando comparamos a resposta encontrada nos camundongos deficientes com a obtida com os camundongos selvagens notamos que houve redução significativa nos níveis de IL-12p40 produzidos independentemente da natureza do estímulo (Figura 10B). Esses dados mostram que o receptor TLR-4 está envolvido com vias de sinalização que regulam a síntese desta citocina, neste modelo de ativação com B. pertussis.

Ao fazermos o mesmo tipo de análise estimulando os M $\phi \mathrm{DM}$ de camundongos $\mathrm{C} 3 \mathrm{H} / \mathrm{HeJ}$ com Ag de B. parapertussis ou com a infecção ativa (Figura 11A), observamos que as células de camundongos deficientes produziram IL-12p40 significativamente independente se a ativação foi realizada com Ag solúvel ou infecção ativa. Porém, diferentemente do obtido com B. pertussis, apesar da redução aparente, não houve diferença significativa quando comparamos os valores obtidos entre os camundongos selvagens C57BL/6 e os deficientes $\mathrm{C} 3 \mathrm{H} / \mathrm{HeJ}$ (Figura 11B).

Estes resultados sugerem que há diferença entre estas duas espécies de Bordetella quanto a capacidade de ativar o TLR-4 e a produção de IL-12p40 no primeiro contato. Os dados mostram que a síntese desta citocina pelos M $\phi D M$ infectados com B. pertussis é dependente de TLR-4 enquanto com B. parapertussis não depende exclusivamente deste receptor podendo envolver outros TLRs e vias de sinalização. 
Figura 10 - Participação do receptor TLR-4 na indução da síntese de IL-12p40 em M $\phi D M$ estimulados com antígeno solúvel ou infectados ativamente com $B$. pertussis

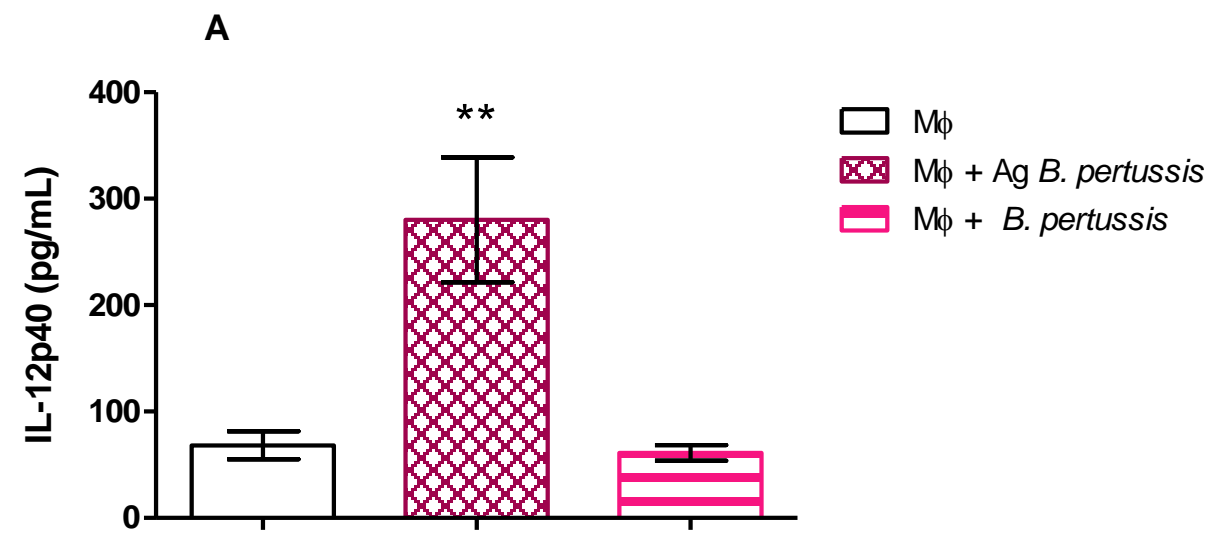

B

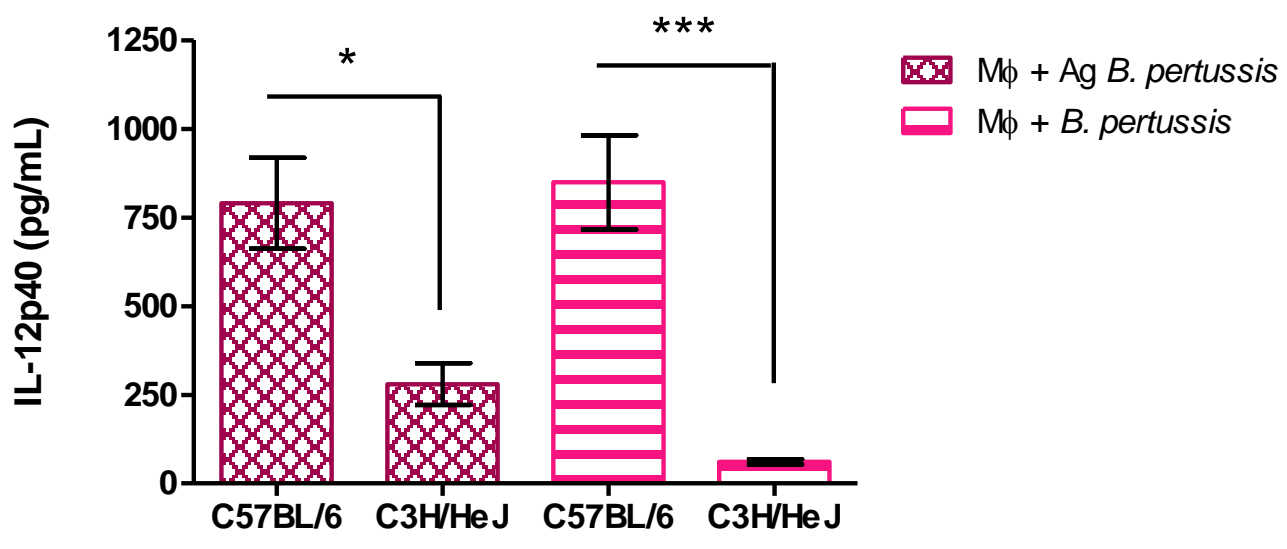

Os $\mathrm{M} \phi \mathrm{DM}$ de $\mathrm{C} 3 \mathrm{H} / \mathrm{HeJ}$ e C57BL/6 (7,5x10\%/poço) foram estimulados com de Ag de B. pertussis (30 $\mu \mathrm{g} / \mathrm{mL})$ ou infectados ativamente $(\mathrm{DO}=1)(\mathrm{A}$ e $\mathrm{B})$. O sobrenadante foi colhido após 20h para a dosagem de IL-12p40. Os resultados representam a média com o erro padrão (SEM) de três ensaios independentes, realizados em duplicata. ** $\mathrm{p}<0,01$ comparando o grupo não estimulado $(\mathrm{M} \phi)$ com o grupo estimulado com Ag de B. pertussis (A); * p <0,05 comparando M $\phi \mathrm{DM}$ de C57BL/6 e C3H/HeJ estimulados com Ag de B. pertussis (B); *** $\mathrm{p}<0,0001$ comparando M $\phi \mathrm{DM}$ de C57BL/6 e C3H/HeJ infectados com B. pertussis (B). 
Figura 11 - Participação do receptor TLR-4 na indução da síntese de IL-12p40 em MфDM estimulados com antígeno solúvel ou infectados ativamente com $B$. parapertussis

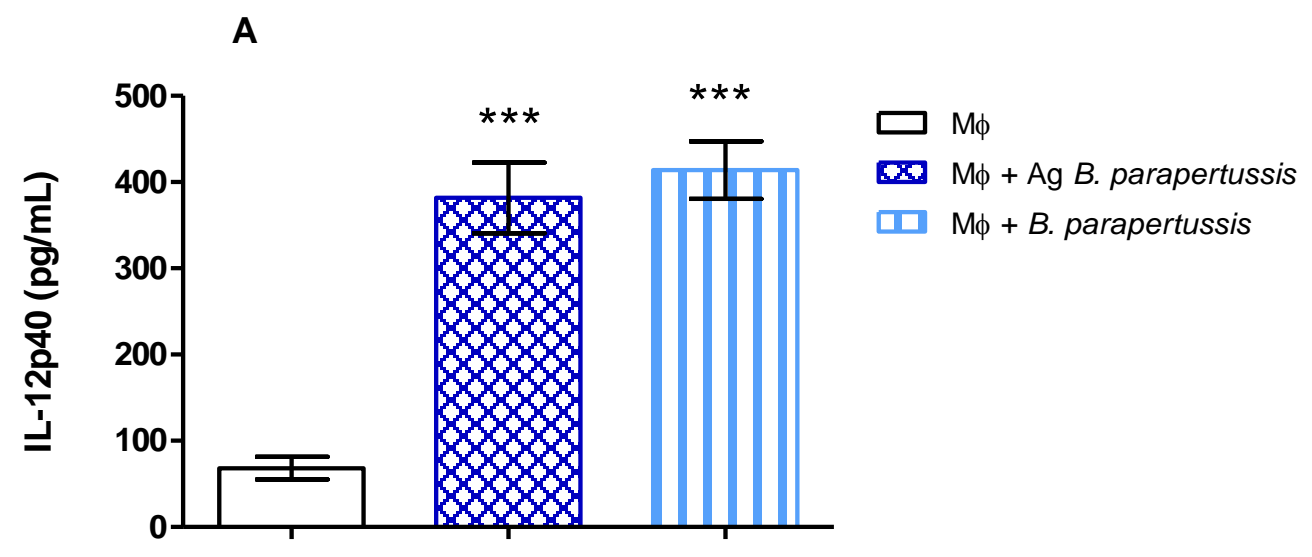

B

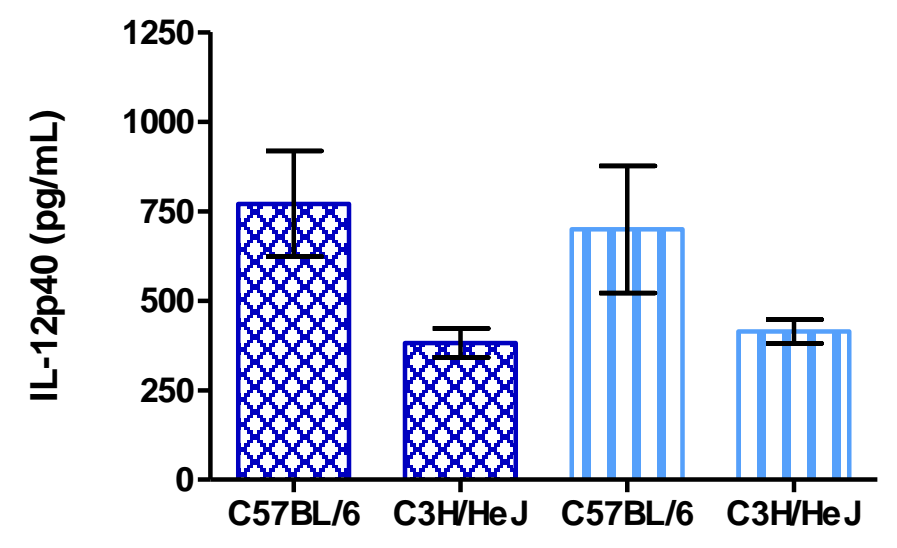

$\mathrm{M} \phi+\mathrm{Ag}$ B. parapertussis

$\square \mathrm{M} \phi+$ B. parapertussis

Os M $\phi D M$ (7,5x10\% $/$ poço) de $\mathrm{C} 3 \mathrm{H} / \mathrm{HeJ}$ e de C57BL/6 foram estimulados com de Ag de $B$. parapertussis $(30 \mu \mathrm{g} / \mathrm{mL})$ ou infectados ativamente $(\mathrm{DO}=1)(\mathrm{A}$ e $\mathrm{B}) \mathrm{O}$ sobrenadante foi colhido após 20h para a dosagem de IL-12p40. Os resultados representam a média com o erro padrão (SEM) de dois ensaios independentes, realizados em duplicata. *** $\mathrm{p}<0,0001$ comparando o grupo não estimulado $(\mathrm{M} \phi)$ com o grupo estimulado com Ag de B. parapertussis e com o grupo infectado ativamente (B). 
4.5 Análise da síntese de IL-12p70 em M $\phi D M$ ativados com $B$. pertussis e $B$. parapertussis

\subsubsection{Ativação dos M $\phi \mathrm{DM}$ com o antígeno solúvel ou infecção ativa}

Apesar de a literatura descrever que há uma correlação entre a presença da subunidade IL-12p40 e IL-12p70, a detecção desta última rotineiramente não é fácil. Em função disto analisamos se a estimulação in vitro com essas duas espécies de Bordetella induziria também a produção de IL-12p70.

Nossos dados mostraram que M $\phi \mathrm{DM}$ estimulados com os Ags solúveis (Figura 12A) ou com a infecção ativa por B. pertussis e B. parapertussis (Figura 12B) não produzem IL12p70, sendo os níveis encontrados próximos ao obtido com as células não ativadas. Enquanto, o grupo controle usando M $\phi D M$ ativados com LPS de E. coli e IFN- $\gamma$ produziu níveis significativos dessa citocina. Isto indica que apesar das diferenças estruturais entre o LPS de B. parapertussis e de B. pertussis e a presença de toxina pertussis nesta última, não foi possível detectar a presença da proteína IL-12p70 quando os $\mathrm{M} \phi \mathrm{DM}$ foram ativados por estas bactérias. 
Figura 12 - Produção de IL-12p70 após ativação de MфDM com $B$. pertussis e $B$. parapertussis

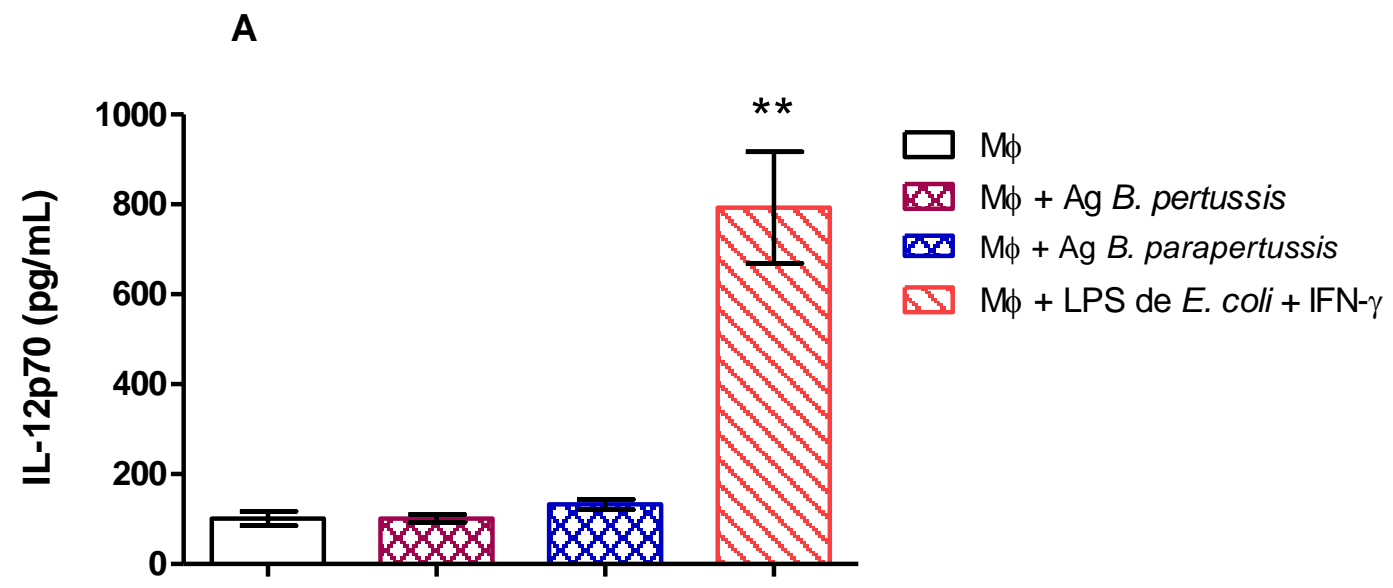

B

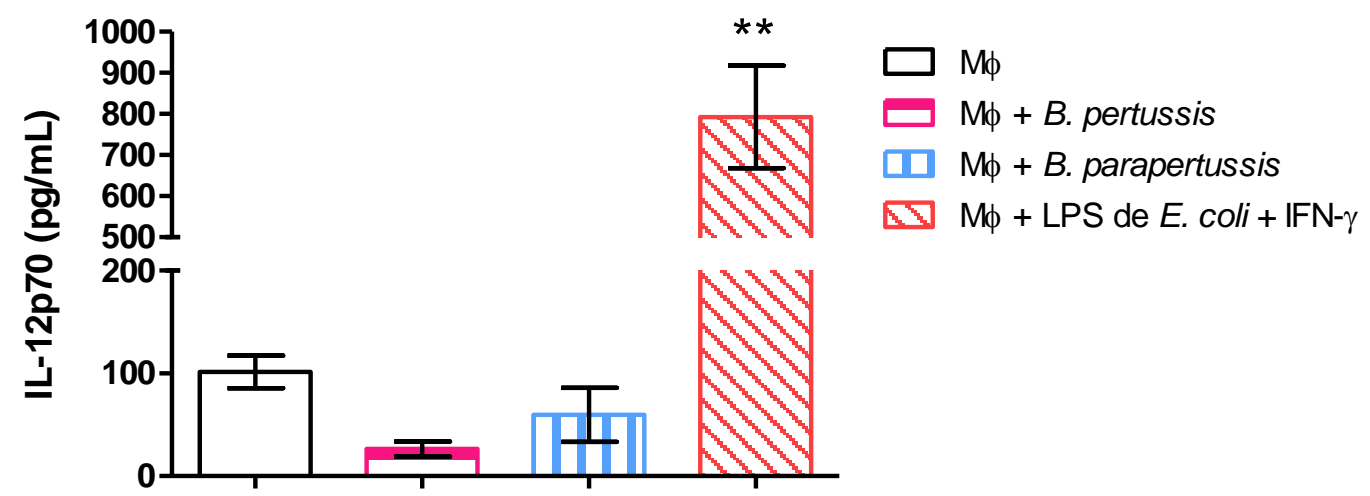

Os M $\phi \mathrm{DM}\left(7,5 \times 10^{5} /\right.$ poço) de C57BL/6 foram estimulados com Ag de B. pertussis e B. parapertussis $(30 \mu \mathrm{g} / \mathrm{mL})(\mathrm{A})$ ou infectados ativamente $(\mathrm{DO}=1)(\mathrm{B})$. O sobrenadante foi colhido após $20 \mathrm{~h}$ para a dosagem de IL-12p70. Os resultados representam a média com o erro padrão (SEM) de três ensaios independentes, realizados em duplicata. ** $\mathrm{p}<0,01$ comparando o grupo não estimulado $(\mathrm{M} \phi)$ e o grupo estimulado com LPS + IFN- $\gamma$. 


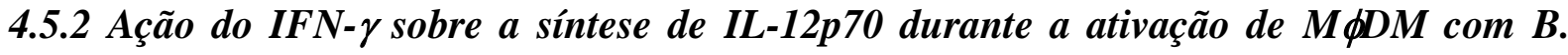 pertussis e B. parapertussis}

Como não foi detectada a presença de IL-12p70 pelos $M \phi D M$ estimulados com as proteínas solúveis de $B$. pertussis ou $B$. parapertussis, analisamos se a presença de IFN- $\gamma$ que pode ser produzido durante a resposta imune inata seria importante para primar os $\mathrm{M} \phi \mathrm{DM}$ ativados com essas bactérias a sintetizar IL-12p70.

Os resultados obtidos mostraram que a adição de IFN- $\gamma$ às culturas de M $\phi D M$ ativados com os Ags de ambas as bactérias favoreceu o aumento da síntese de IL-12p70 de modo significativo (Figura 13A e 13B). O aumento foi respectivamente de 4,63 e 2,02 vezes para $B$. pertussis e $B$. parapertussis em relação às células estimuladas somente com o Ag. Os M $\phi D M$ estimulados individualmente com IFN- $\gamma$ não produziram IL-12p70, porém o grupo controle, LPS de E. coli e IFN- $\gamma$, induziu níveis elevados desta citocina. Isto mostra que a presença do IFN- $\gamma$ é fundamental no início do contato das bactérias com os macrófagos, sendo um sinal molecular importante para a geração da molécula bioativa IL-12p70 durante a ativação dos macrófagos com estas bactérias. 
Figura 13 - Efeito do IFN- $\gamma$ sobre a síntese de IL-12p70 por $M \phi D M$ estimulados com antígeno de $B$. pertussis e $B$. parapertussis

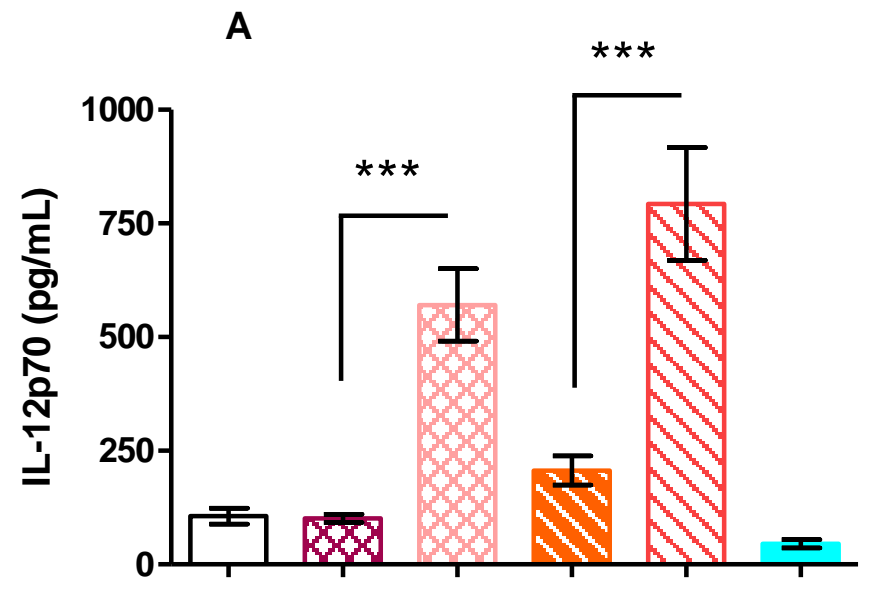

Ag B. pertussis

IFN- $\gamma$

LPS de E. coli

B

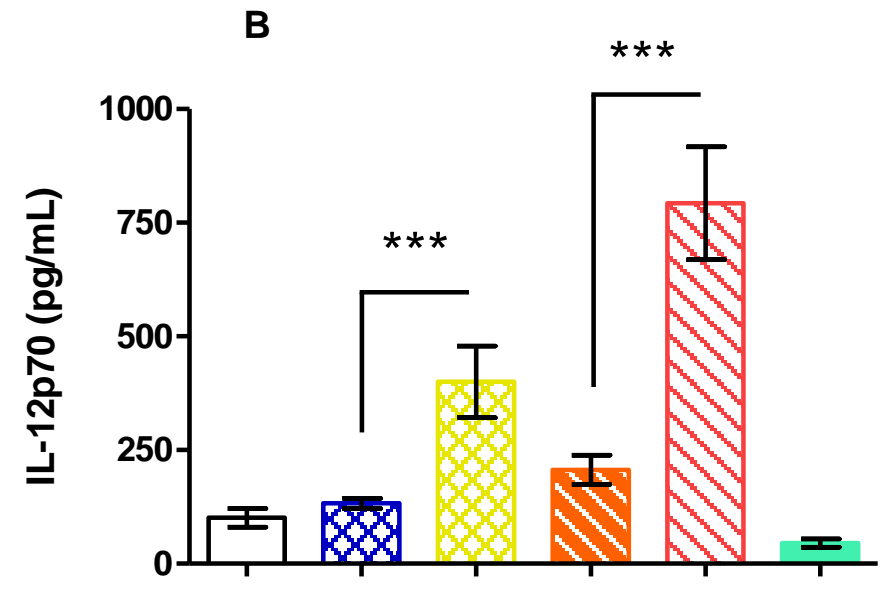

Ag B. parapertussis

IFN- $\gamma$

LPS de E. coli

Os M $\phi \mathrm{DM}\left(7,5 \times 10^{5} /\right.$ poço) de C57BL/6 foram ativados com Ag de B. pertussis (A) ou Ag de B. parapertussis $(30 \mu \mathrm{g} / \mathrm{mL})$ (B) juntamente com IFN- $\gamma(2 \mathrm{ng} / \mathrm{mL})$. Após 20 horas o sobrenadante foi obtido para a dosagem de IL-12p70. Os resultados representam a média com o erro padrão (SEM) de três ensaios independentes, realizados em duplicata. $* * * \mathrm{p}<0,0001$ comparando o grupo tratado apenas com Ag solúvel e o que recebeu Ag + IFN- $\gamma$ e comparando o grupo tratado apenas com LPS e o que recebeu LPS + IFN- $\gamma$. 
4.6 Investigação de vias de sinais intracelulares que controlam a síntese de IL-12p40 durante a ativação de $\mathrm{M} \phi \mathrm{DM}$ com antígeno solúvel de $B$. pertussis e $B$. parapertussis

\subsubsection{Efeito do bloqueio específico do NF KB na síntese de IL-12p40}

O NFKB é um fator de transcrição que é ativado por uma variedade de componentes de microrganismos que sinalizam através dos TLRs e assim regula a transcrição de diversos genes associados a resposta inflamatória. Portanto, avaliamos em seguida o efeito do inibidor

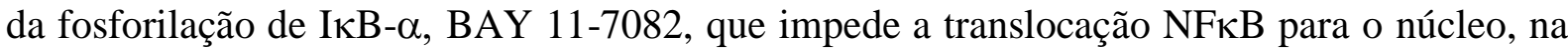
síntese de IL-12p40 durante a ativação de M $\phi D M$ com componentes solúveis de $B$. pertussis ou de B. parapertussisis.

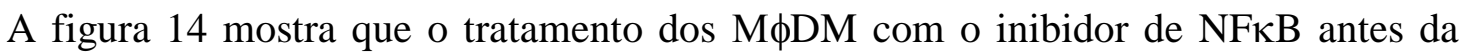
ativação com $\mathrm{Ag}$ de $B$. pertussis (Figura 14A) e de B. parapertussisis (Figura 14B) reduziu significativamente a produção de IL-12p40, indicando que este fator de transcrição é importante para síntese de IL-12p40 durante a ativação dos M $\phi \mathrm{DM}$ com o Ag de ambas as espécies de Bordetella e envolve a participação dos TLRs ou de outros PRRs que também ativam o NFkB. 
Figura 14 - Efeito da inibição de NFkB na regulação da síntese de IL-12p40 durante a ativação de $M \phi D M$ com antígeno de $B$. pertussis e $B$. parapertussis
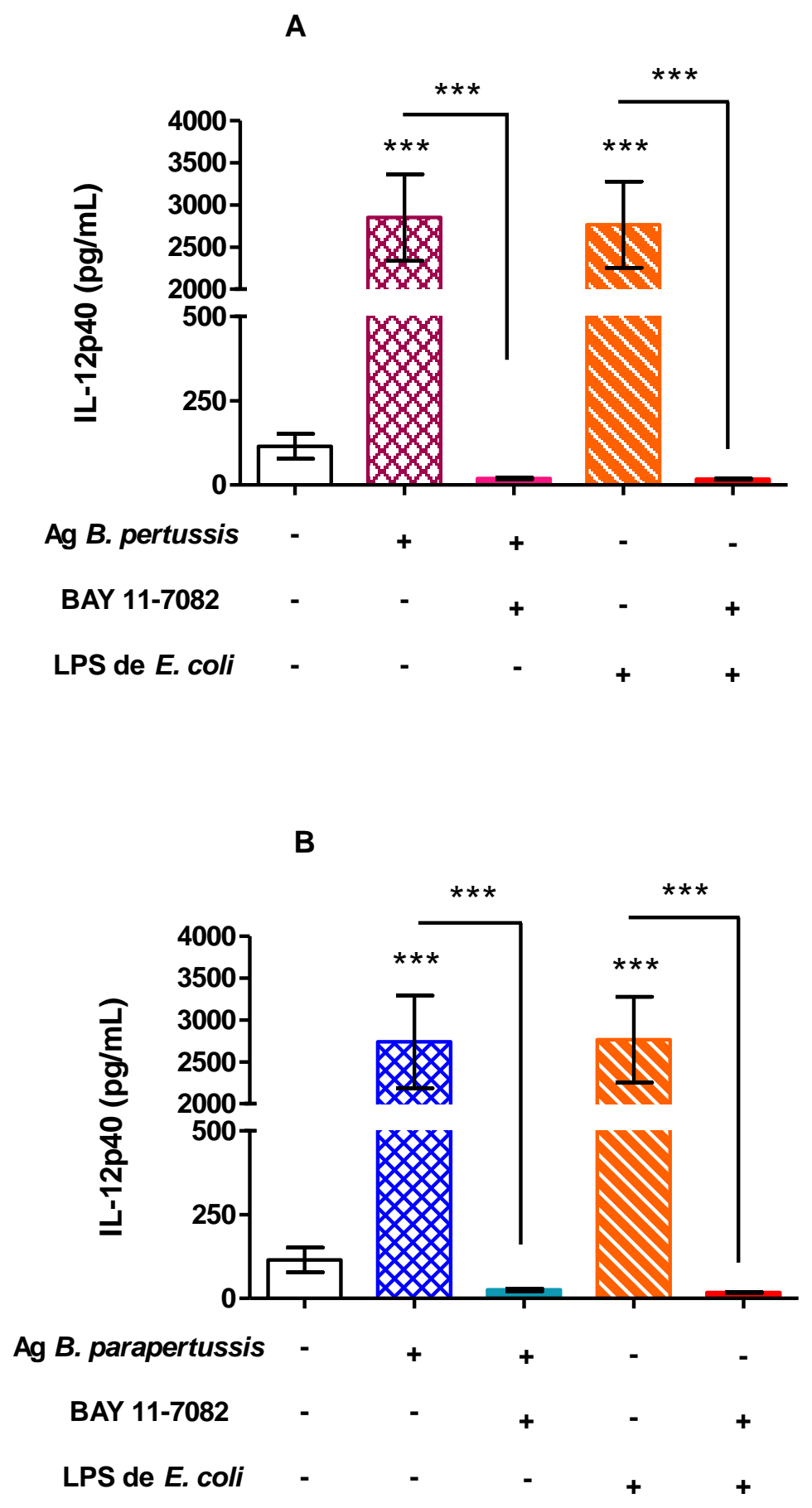

Os M $\phi \mathrm{DM}\left(7,5 \times 10^{5} /\right.$ poço) de C57BL/6 foram pré-tratados com o inibidor BAY 11-7082 (10 $\left.\mu \mathrm{M}\right)$ por 1hora antes da ativação com $30 \mu \mathrm{g} / \mathrm{mL}$ de $\mathrm{Ag}$ de B. pertussis (A) ou Ag de B. parapertussis (B). Após 20 horas o sobrenadante foi obtido para a dosagem de IL-12p40. Os resultados representam a média com o erro padrão (SEM) de três ensaios independentes, realizados em duplicata. $* * * \mathrm{p}<0,0001$ comparação entre o grupo não estimulado $(\mathrm{M} \phi)$ e o estimulado com $\mathrm{Ag}$ e entre o grupo estimulado na presença e ausência do inibidor (A, B). 
4.6.2 Efeito de inibidores específicos de MAPkinases p38 e ERK1/2 na produção de IL$12 p 40$ e IL-12p70 durante o estímulo de M $\phi \mathrm{DM}$ com antígeno solúvel de B. pertussis ou B. parapertussis

A regulação da síntese de algumas citocinas em resposta a ativação dos TLRs devido à interação com seus agonistas está relacionada não somente a ativação de NFkB, mas também a vias que envolvem a ativação das MAPKs. Assim, investigamos a participação de duas subfamílias das MAPKs, p38 e ERK1/2, na síntese de IL-12. Para isso, as células foram prétratadas com o inibidor farmacológico específico de p38 (SB202190) ou o inibidor de ERK1/2 (PD98059), sendo posteriormente ativadas com o Ag solúvel bacteriano.

Nossos resultados mostraram que o bloqueio de p38 e ERK1/2 não afetou a produção de IL-12p40, não havendo diferença significativa entre os grupos estimulados com Ag de $B$. pertussis ou Ag de B.parapertussis na presença ou ausência destes inibidores no modelo estudado (Figura 15A e 15B), sugerindo que MAPKs p38 e ERK1/2 não são as principais vias que regulam a produção de IL-12p40 durante a ativação de M $\phi D M$ com as duas espécies de bactérias.

Como a regulação da síntese da subunidade p40 pode diferir do heterodímero p70, investigamos o mesmo efeito de inibição de MAPKs sobre a síntese de IL-12p70 que é a forma biologicamente ativa deste mediador. Diferentemente do observado com a IL-12p40, a inibição de p38 ou ERK 1/2 aumentou significativamente a produção de IL-12p70 pelos M $\phi D M$ estimulados com os antígenos de B. pertussis (Figura 16A) e de B.parapertussis (Figura 16B), indicando que p40 e IL-12p70 podem ser regulados diferentemente pelas vias das MAPKs investigadas durante a ativação dos macrófagos com estas bactérias, independentemente da espécie estudada. 
Figura 15 - Papel das MAPkinases p38 e ERK1/2 na regulação da síntese de IL-12p40 em M $\phi D M$ estimulados com antígeno solúvel de $B$. pertussis ou $B$. parapertussis

A
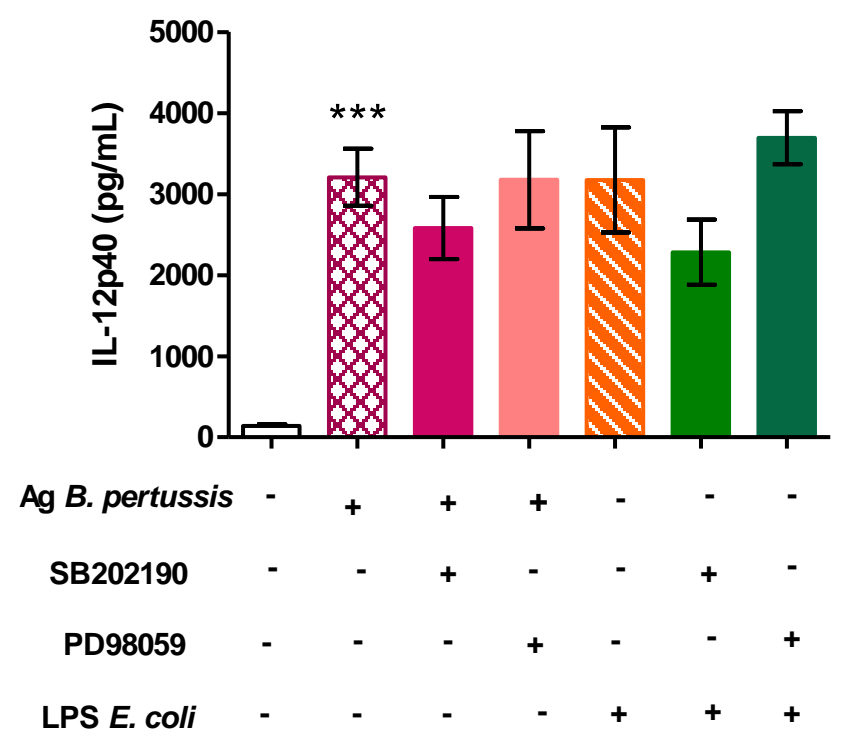

B

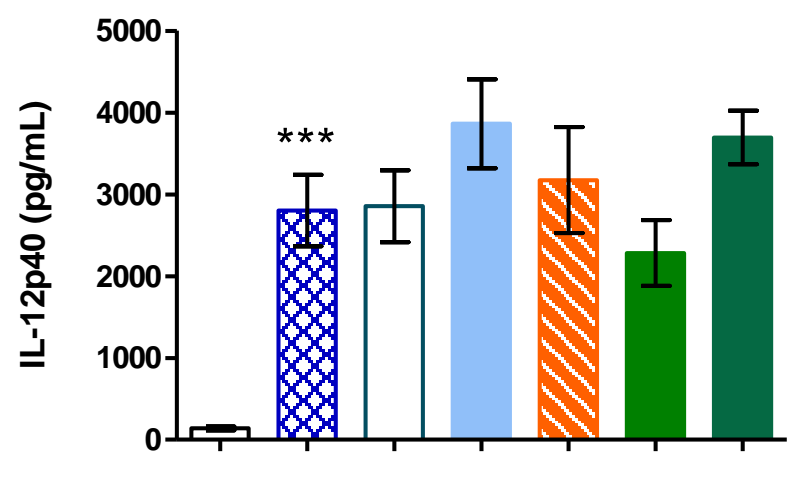

Ag B. parapertussis

SB202190

PD98059

LPS E. coli

Os $\mathrm{M} \phi \mathrm{DM}\left(7,5 \times 10^{5} /\right.$ poço) de C57BL/6 foram pré-tratados por $1 \mathrm{~h}$ com SB202190 (10 $\left.\mu \mathrm{M}\right)$ ou PD98059 $(20 \mu \mathrm{M})$ e posteriormente estimulados com $30 \mu \mathrm{g} / \mathrm{mL}$ de $\mathrm{Ag}$ de B. pertussis (A) ou de Ag de B. parapertussis (B). Após 20 horas, o sobrenadante foi obtido para a dosagem de IL-12p40. Os resultados representam a média com o erro padrão (SEM) de cinco ensaios independentes, realizados em duplicata em duplicata. ${ }^{* * *} \mathrm{p}<0,0001$ em relação ao grupo não estimulado $(\mathrm{M} \phi)$. 
Figura 16 - Papel das MAPkinases p38 e ERK1/2 na regulação da síntese de IL-12p70 em M $\phi D M$ estimulados com antígeno solúvel de $B$. pertussis ou $B$. parapertussis
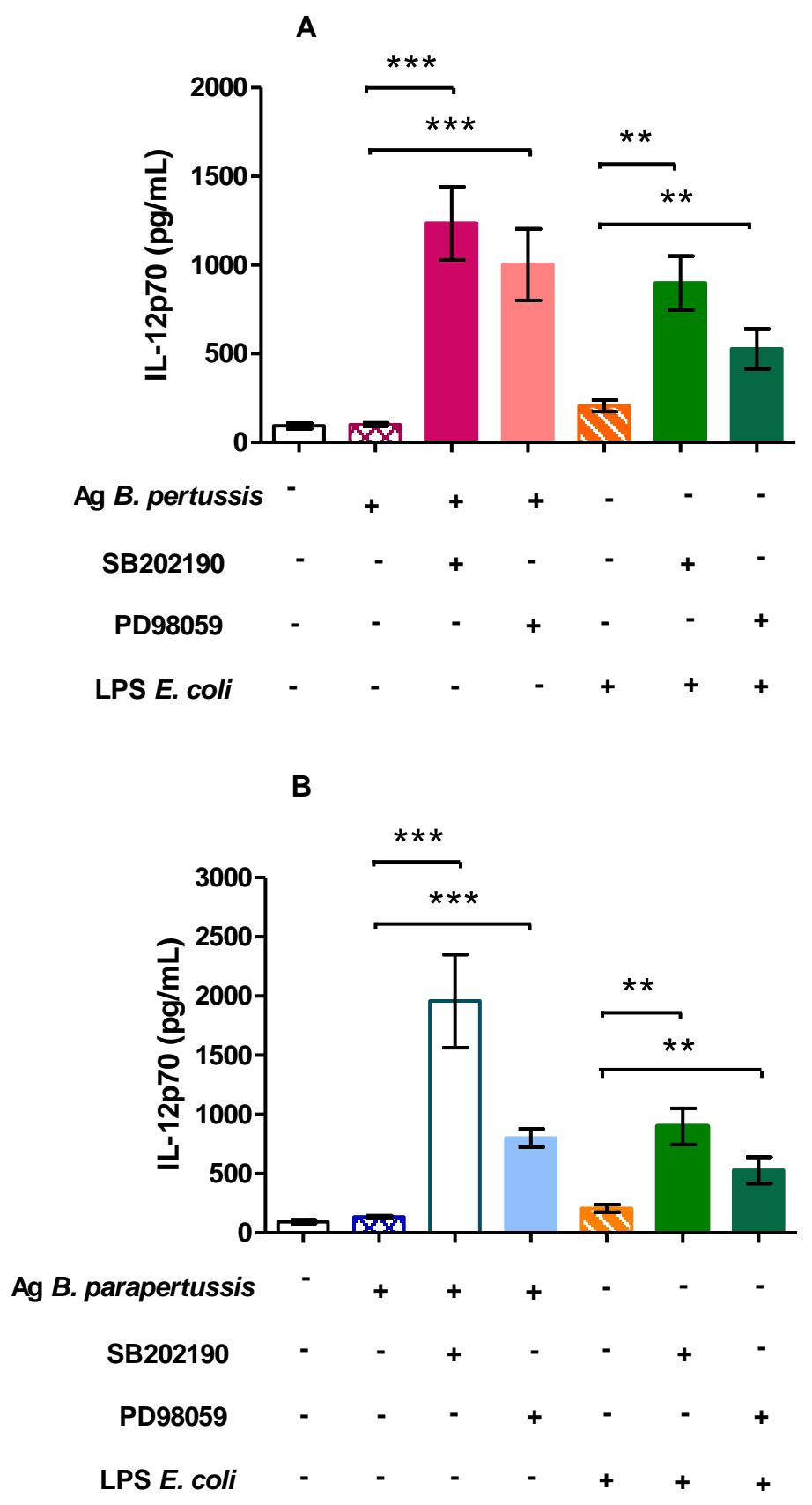

Os $\mathrm{M} \phi \mathrm{DM}\left(7,5 \times 10^{5} /\right.$ poço) de C57BL/6 foram pré-tratados por $1 \mathrm{~h}$ com SB202190 (10 $\left.\mu \mathrm{M}\right)$ ou PD98059 $(20 \mu \mathrm{M})$ e posteriormente estimulados com $30 \mu \mathrm{g} / \mathrm{mL}$ de $\mathrm{Ag}$ de B. pertussis (A) ou de Ag de B. parapertussis (B). Após 20 horas, o sobrenadante foi obtido para a dosagem de IL-12p70. Os resultados representam a média com o erro padrão (SEM) de três ensaios independentes, realizados em duplicata. $* * * \mathrm{p}<0,0001 ; * * \mathrm{p}<0,01$ comparação entre o grupo estimulado tratado ou não com o inibidor (A, B). 


\subsubsection{Inibição de PI3K regula a síntese de IL-12p70 em M $\phi D M$ estimulados com antígeno} solúvel de B. pertussis ou B. parapertussis

A sinalização via TLR também ativa a PI3K que pode regular a produção de citocinas. Em seguida analisamos a contribuição de PI3K na regulação da síntese de IL-12p70, prétratando os M $\phi \mathrm{DM}$ com a vortimanina, inibidor específico desta via, antes da ativação das células com os Ags de B. pertussis ou B. parapertussis. A figura 17A e 17B mostra que o bloqueio desta via aumentou significativamente a síntese de IL-12p70 pelos M $\phi D M$ estimulados com ambos os Ags bacterianos, os valores obtidos foram superiores quando comparado às células não tratadas com esse inibidor. Isto mostra que a via da PI3K está envolvida na regulação da síntese de IL-12p70 durante a ativação dos M $\phi D M$ com os Ags de B. pertussis ou B. parapertussis. 
Figura 17 - Efeito da inibição de PI3K na regulação da síntese de IL-12p70 em M $\phi D M$ ativados com antígeno solúvel de $B$. pertussis e $B$. parapertussis
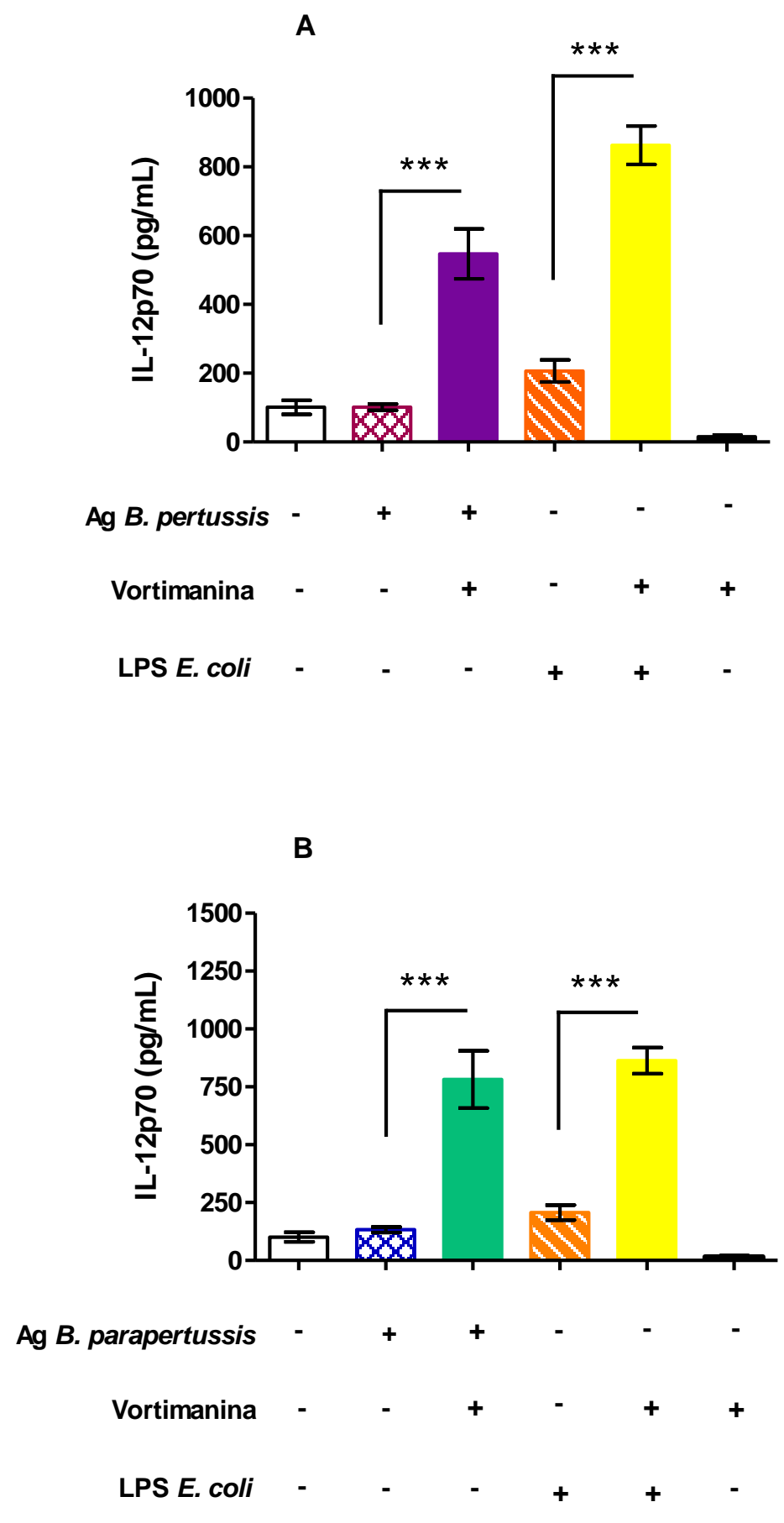

Os M $\phi \mathrm{DM}\left(7,5 \times 10^{5} /\right.$ poço) de C57BL/6 foram pré-tratados por $1 \mathrm{~h}$ com vortimanina (100 $\left.\mathrm{nM}\right)$ antes do estímulo com $30 \mu \mathrm{g} / \mathrm{mL}$ de Ag de B. pertussis (A) ou de Ag de B. parapertussis (B). Após 20 horas, o sobrenadante foi obtido para a dosagem de IL-12p70. Os resultados representam a média com o erro padrão (SEM) de três ensaios independentes, realizados em duplicata. $* * * \mathrm{p}<0,0001$ comparando o grupo estimulado com o grupo estimulado tratado com o inibidor (A, B). 


\subsubsection{Regulação da síntese de IL-12p70 por meio da sinalização via proteína Ga inibitória} em M $\phi D$ M estimulados com antígeno solúvel de B. parapertussis

A PT é um dos principais fatores de virulência produzido exclusivamente por $B$. pertussis e é um conhecido inibidor da sinalização via proteína Gai que resulta no aumento de AMPc intracelular, o qual pode refletir na regulação da síntese de IL-12p70. Portanto, investigamos se a adição desta toxina sobre $B$. parapertussis, que não expressa a $\mathrm{PT}$, modificaria a síntese desta citocina. Para avaliar o efeito desta sinalização os M $\phi D M$ foram pré-tratados com PT purificada e posteriormente estimulados com antígeno solúvel de $B$. parapertussis.

A Figura 18 mostra que a adição de PT sobre os M $\phi D M$ ativados aumentou significativamente a síntese de IL-12p70 em comparação com os M $\phi D M$ estimulados apenas com o $\mathrm{Ag}$ de $B$. parapertussis. Isto sugere que a sinalização via proteína Gai é importante para controlar a produção de IL-12p70 durante a ativação dos M $\phi D M$ com os componentes solúveis de B. parapertussis.

\section{Figura 18 - Influência da toxina pertussis na síntese de IL-12p70 em M $\phi D M$ ativados com antígeno solúvel de $B$. parapertussis}
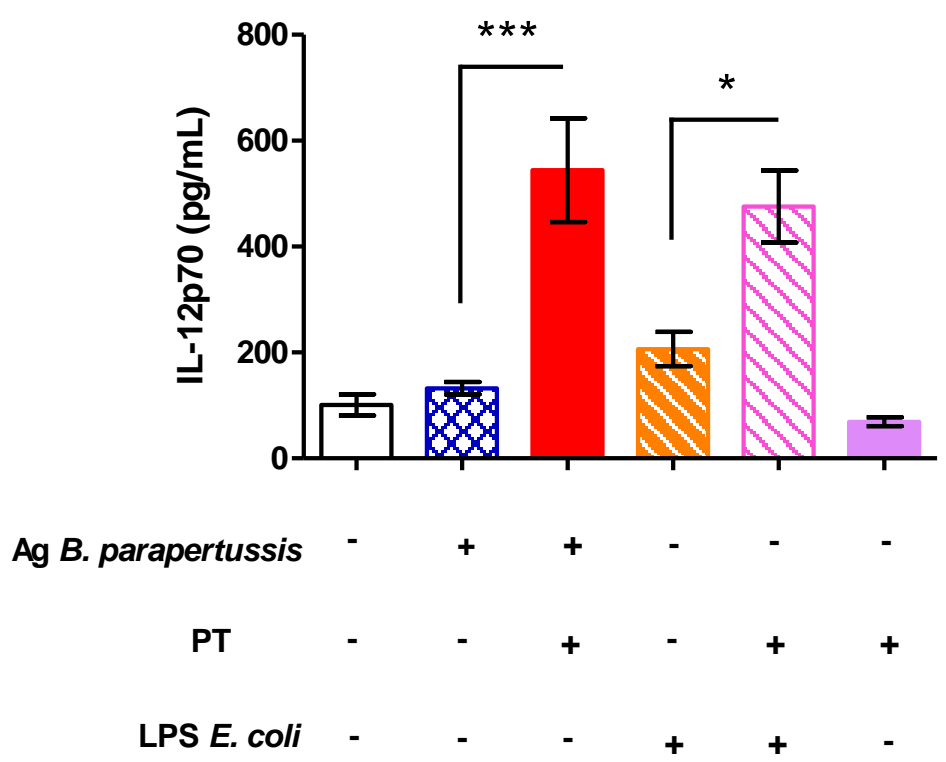

Os $\mathrm{M} \phi \mathrm{DM}\left(7,5 \times 10^{5} /\right.$ poço $)$ de C57BL/6 foram pré-tratados por $1 \mathrm{~h}$ com PT $(0,5 \mu \mathrm{g} / \mathrm{mL})$ e posteriormente estimulados com $30 \mu \mathrm{g} / \mathrm{mL}$ Ag de B. parapertussis. Após 20 horas, o sobrenadante foi obtido para a dosagem de IL-12p70. Os resultados representam a média com o erro padrão (SEM) de três ensaios independentes, realizados em duplicata. $* * * \mathrm{p}<0,0001 ; * \mathrm{p}<0,05$ comparando o grupo estimulado tratado ou não com PT. 


\section{DISCUSSÃO}

A reemergência da coqueluche em populações com alta cobertura vacinal é motivo de preocupação em diversos países, incluindo o Brasil. Um dos fatores atribuídos a este fato é a adaptação de Bordetella pertussis ao organismo hospedeiro imunizado, podendo haver uma seleção de bactérias com fatores de virulência mais resistentes ao processo de vacinação, dentre eles a toxina pertussis (PT) e a pertactina (PRN), o que pode alterar a eficácia da vacina (VAN DER ARK et al., 2012). Outro aspecto importante associado a isto é o fato de desconhecemos muito dos mecanismos de ação atribuídos a estes fatores de virulência que definem a persistência e adaptação desta bactéria ao organismo humano. Isto significa que estudos sobre os aspectos da interação do patógeno com células do sistema imune do hospedeiro podem contribuir para melhorar as vacinas existentes e reduzir a incidência desta infecção.

A infecção com $B$. pertussis e $B$. parapertussis é prevalente em humanos. Para compreendermos os aspectos de interação entre estas bactérias com a célula humana, estabelecemos um modelo in vitro a fim de estudar a interação entre estas duas bactérias e os macrófagos que são as principais células imunes envolvidas no reconhecimento de patógenos e definição da resposta imune inata e adaptativa.

Analisamos inicialmente se estas bactérias diferem na capacidade de induzir a síntese de IL-12. Esta citocina estimula as células NK a sintetizar IFN- $\gamma$, o qual ativa os macrófagos a produzirem mediadores inflamatórios, e a diferenciação de subpopulação de linfócitos $\mathrm{T}$ $\mathrm{CD}^{+}$Th1, fundamentais para a erradicação de diversas infecções. Isto pode auxiliar no entendimento do processo patológico bem como para a definição da atividade efetora de vacinas ou outras drogas importantes no combate a esta doença.

Os macrófagos fagocitam e recrutam outros tipos celulares para o local de infecção através da liberação de quimiocinas e citocinas, iniciando a resposta imune adaptativa para diversos patógenos (MURRAY; WYNN, 2011).

A glicoproteína F4/80 é o marcador de superfície celular comumente usado para identificar macrófagos murinos (MURRAY; WYNN, 2011) e a presença do M-CSF é crítico para a diferenciação das células progenitoras da medula óssea em macrófagos. Estas células diferenciadas expressam F4/80 e CD11b (KADOWAKI et al., 2012). Sendo assim, o anticorpo F4/80 foi utilizado para caracterizar o fenótipo das células hematopoiéticas da medula óssea diferenciadas in vitro e obtivemos uma população exclusiva de macrófagos (Figura 5). A escolha desta população de macrófagos foi em função desta representar as 
células que estão distribuídas pelos diversos órgãos e estar na sua forma naive, pois ainda não entrou em contato com nenhum antígeno.

Durante a resposta inata, após o primeiro contato dos macrófagos com produtos microbianos, há produção de diversos mediadores imunes dentre eles IL-12 e TNF- $\alpha$.

A IL-12 é composta por duas subunidades, p35 e p40, codificadas por genes separados que são regulados independentemente (BABIK et al., 1999). A subunidade p40 é produzida em excesso em relação ao heterodímero IL-12p70 (TRINCHIERI, 1996). Em função disto, optamos por quantificar a presença de IL-12p40 e TNF- $\alpha$ no sobrenadante das culturas de M $\phi D M$ estimulados ou infectados por B. pertussis e B. parapertussis. Nossos resultados mostraram que os produtos de ambas as bactérias induziram a ativação dos $\mathrm{M} \phi \mathrm{DM}$ de camundongos C57BL/6 a secretarem IL-12p40 e TNF- $\alpha$ independente se utilizamos componentes solúveis ou infecção ativa (Figura 6 e 7).

O resultado da interação entre patógeno e célula hospedeira é determinado pelo tipo de receptor no qual é ligado (HOEPELMAN; TUOMANEN, 1992). Assim, o estímulo com os componentes solúveis de $B$. pertussis ou $B$. parapertussis e a infecção com as bactérias vivas podem ativar diferentes receptores para mediar a sinalização intracelular. Além disto, a quantidade de proteínas presentes no lisado bacteriano pode ter sido superior ao que foi gerado pelas bactérias fagocitadas e destruídas intracelularmente, resultando na diferença dos níveis de TNF- $\alpha$ produzidos por estes fagócitos quando ativados com Ag solúvel em comparação com a infecção ativa (Figura 7). No entanto, isto não se refletiu na síntese de IL12p40, pois os níveis obtidos em resposta ao Ag e a infecção ativa foram similares (Figura 6).

Foi sugerido que o TNF- $\alpha$ é essencial para a proteção contra a infecção do trato respiratório murino com $B$. pertussis, podendo bloquear alguns dos efeitos mediados por PT durante a infecção. A presença de TNF- $\alpha$ induz a produção de quimiocinas por uma variedade de tipos celulares, além de aumentar a expressão de moléculas de adesão e facilitar o extravazamento dos leucócitos do sangue para o local da injúria durante a resposta inflamatória (WOLFE et al., 2007).

As duas espécies de Bordetella usadas neste trabalho são espécies intimamente relacionadas que compartilham grande número de fatores de virulência que facilitam a colonização do trato respiratório do hospedeiro, mas apresentam diferenças em alguns destes fatores indicando que cada uma das espécies pode ter uma maneira própria de modificar a resposta imune a fim de otimizar a sua capacidade de infectar o hospedeiro (MANN et al., 2005). 
Uma das principais diferenças entre $B$. pertussis e $B$. parapertussis é o fato desta última não expressar a PT (ARICO; RAPPUOLI, 1987). Além disto, as duas bactérias diferem na estrutura da molécula de LPS em relação a distribuição de ácidos graxos do lipídio A (CAROFF et al., 2002) e a ausência do antígeno O em B. pertussis (GOEBEL et al., 2008). As alterações na estrutura do lipídio A, porção da molécula de LPS de bactérias Gramnegativas reconhecida pelo TLR-4, podem resultar em variações na capacidade de produção de TNF- $\alpha$ por macrófagos ativados (JOHN; LIU; JARVIS, 2009).

O TNF- $\alpha$ pode estimular ou inibir a produção de IL-12, dependendo da natureza do estímulo recebido pelo macrófago. No início da resposta imune, esta citocina sinaliza para os macrófagos estimulando-os a produzir IL-12 (FLESCH et al., 1995). Além disso, a sinalização via TNF- $\alpha$ causa aumento do receptor 1 do TNF (TNFR1) e do CD40 em macrófagos. Essa sinalização através do TNFR1 é inibitória para produção de IL-12, enquanto que a mediada pela interação das moléculas CD40-CD40L promove a produção de IL-12 (ZAKHAROVA; ZIEGLER, 2005).

Nossos resultados sugerem que o TNF- $\alpha$ está envolvido na regulação da síntese de IL12 p40 neste modelo, uma vez que o bloqueio usando o anticorpo específico para TNF- $\alpha$ reduziu a síntese de IL-12p40 durante a ativação com B. pertussis e B. parapertussis (Figura 8A e 8B). Apesar do efeito sinérgico entre essas duas citocinas na regulação da resposta inflamatória, o estudo utilizando macrófagos derivados de monócitos humanos, mostrou que o TNF- $\alpha$ pode inibir a transcrição do gene p40, mas não do gene p35 (MA et al., 2000).

Diversos agonistas de TLRs, dentre eles o LPS, induzem a produção de IL-12 por macrófagos e DCs (WATFORD et al., 2003). Entretanto, outros componentes presentes no extrato bacteriano colaboram para a indução desta citocina, pois o tratamento de antígenos solúveis com a polimixina $\mathrm{B}$, antibiótico que se liga ao lipídio A da molécula de LPS e neutraliza seu efeito biológico, reduziu, mas não bloqueou totalmente a produção de IL-12p40 uma vez que estas células continuaram a produzir valores significativos desta citocina (dados não mostrados).

Os macrófagos possuem vários TLRs que reconhecem moléculas conservadas presentes em microrganismos. A sinalização mediada via estes receptores é fundamental para a resposta imune. Exceto o TLR-3 que requer o TRIF como adaptador, os demais TLRs requerem a molécula adaptadora MyD88 (KOH et al., 2010). Somente o TLR-4 utiliza MyD88 e TRIF (TAKEDA; AKIRA, 2004). Essas vias de sinalização ativam a transcrição de genes que codificam as subunidades da IL-12 (TRINCHIERI; SHER, 2007). 
A via dependente de MyD88 ativa NFkB e MAPKs para o controle da síntese de citocinas inflamatórias enquanto a via independente regula a transcrição de genes dependentes de IRF-3 e também ativa NFкB e MAPKs (KAWAI; AKIRA, 2006; KUMAR; KAWAI; AKIRA, 2009).

Nossos dados (Figura 9B e 9C) mostraram que a ausência de MyD88 promoveu drástica redução na produção de IL-12p40 em comparação com as células de animais selvagens, após a estimulação dos M $\phi \mathrm{DM}$ com componentes solúveis de $B$. pertussis e $B$. parapertussis. Isto confirma a importância do TLR na produção desta citocina que se mostrou dependente de MyD88. No entanto, a estimulação com B. parapertussis pode envolver a via de sinalização intracelular independente de MyD88, uma vez que mesmo na ausência desta molécula adaptadora, níveis significativos de IL-12p40 continuaram sendo sintetizados (Figura 9A).

Em infecções com bactérias Gram-negativas, o reconhecimento de LPS por TLR-4 é um dos principais sinais que induzem a produção de citocinas. Foi demonstrado que a ativação de células dendríticas derivadas de monócitos humanos (MDDC) com LPS de $B$. parapertussis, ativou a via independente de MyD88, diferentemente do observado com o de B. pertussis (FEDELE et al., 2008). Além do LPS, outro fator de virulência, a PT, também pode ativar esse receptor. Foi demonstrado que essa toxina pode ativar a via dependente e independente de MyD88 em DCs, enquanto a subunidade B de PT (PTB) ativou preferencialmente a via independente (WANG et al., 2006). Isto mostra que componentes de B. pertussis e B. parapertussis podem ativar as vias dependente ou independente de MyD88.

Para explorar a participação dos TLRs na regulação da síntese de IL-12p40 durante a ativação dos macrófagos por $B$. pertussis e B. parapertussis utilizamos células de animais $\mathrm{C} 3 \mathrm{H} / \mathrm{HeJ}(\mathrm{Tl4} /)$ que são hiporresponsivos ao LPS devido a uma mutação no gene Tlr4.

Os resultados mostraram que a síntese de IL-12p40 pelos M $\phi \mathrm{DM}$ de $\mathrm{C} 3 \mathrm{H} / \mathrm{HeJ}$ ativados com B. pertussis é dependente de TLR-4 (Figura 10B), ao contrário da resposta obtida pela ativação com B. parapertussis (Figura 11B), onde apesar da redução em relação as células de animais selvagens, esta não foi significativa, sugerindo que outros receptores e componentes bacterianos que não sinalizam através do TLR-4 podem estar envolvidos na síntese desta citocina.

A comprovação da importância do TLR-4 na resposta imune desenvolvida contra $B$. pertussis foi evidenciada em outros trabalhos onde a vacina pertussis celular induziu a resposta Th1 e Th17 dependentes da sinalização via esse receptor (HIGGINS et al., 2006). No 
entanto, a contribuição do TLR-4 durante a resposta imune inata no momento do contato direto de macrófagos com $B$. parapertussis ainda é pouco estudada, não havendo informação sobre a síntese de IL-12.

A toxicidade da molécula de LPS é determinada pelo número, comprimento e distribuição dos ácidos graxos que compõem o lipídio A (HAUSCHILDT et al., 2000). Sendo assim, as diferenças na estrutura do lipídio A podem modular diferentemente a resposta inata a várias bactérias Gram-negativas (CHILTON; EMBRY; MITCHELL, 2012). Por exemplo, a Yersinia pestis é capaz de modificar o número e o tipo de ácidos graxos do lipídio A de acordo com a sua temperatura de crescimento. Essa bactéria produz um LPS com baixa capacidade de ativar o TLR-4 e estimula os macrófagos murinos e de humanos a produzirem poucas quantidades de TNF- $\alpha$ a temperatura de $37^{\circ} \mathrm{C}$ que corresponde a temperatura corporal de seu hospedeiro, diferentemente do observado com o LPS sintetizado a temperatura de $26^{\circ} \mathrm{C}$ (KAWAHARA et al., 2002).

Conforme já mencionado a PT ativa e sua subunidade B (PTB) são capazes de ativar TLR-4 em DCs. A produção de citocinas (IL-6, IL-10 e IL-12p40) por DCs murinas requer a presença de TLR-4 em resposta a ativação com PT que é capaz de induzir níveis maiores de citocinas em comparação com o estímulo por PTB (WANG et al., 2006). Em outro trabalho, foi comprovado que baixa dose de PT detoxificada pode ativar sinalizações via TLR-4, enquanto uma dose mais alta ativa de forma mais pronunciada o TLR-2 (NASSO et al., 2009).

A PT pode mediar seus efeitos por duas vias diferentes de sinalização: uma envolve a mobilização da subunidade A para o interior da célula hospedeira levando a ADP ribosilação da subunidade $\alpha$ da proteína $\mathrm{G}$ inibitória, isto é lento e requer baixa concentração da toxina. A segunda via requer alta concentração da toxina e envolve a interação da subunidade B com os receptores sobre as células eucarióticas iniciando uma rápida sinalização que medeia efeitos biológicos independentes da atividade catalítica da subunidade $\mathrm{A}$, incluindo a ativação de MAPK e NFKB (MANGMOOL; KUROSE, 2011).

Estudos in vivo usando linhagens de camundongos deficientes na resposta ao LPS, $\mathrm{C} 3 \mathrm{H} / \mathrm{HeJ}$ e C57BL/10ScNCr infectados com B. bronchiseptica, B. pertussis e $B$. parapertussis mostraram que o TLR-4 é vital para a defesa inata do hospedeiro contra $B$. bronchiseptica. Os camundongos deficientes em TLR-4 apresentaram aumento do número de CFU no pulmão e desenvolveram doença letal diferentemente das outras duas espécies de Bordetella. Na infecção com $B$. pertussis, mas não com B. parapertussis, o TLR-4 foi importante na redução do número de bactérias nos pulmões. Porém, durante a ativação in 
vitro de M $\phi D M$ murinos com LPS purificado destas três espécies de bactérias, o TLR-4 foi essencial para a produção de citocinas como TNF- $\alpha$ e IL-6. Quantidades mínimas do LPS de B. bronchiseptica foram necessárias para ativar este receptor quando comparado ao LPS de $B$. pertussis, enquanto o de B. parapertussis, dentre as três, apresentou a menor capacidade de ativação (MANN et al., 2005). Isto mostra que diferenças na estrutura do LPS entre este grupo de bactérias pode influenciar a capacidade de ativação de TLR-4.

Há sugestões na literatura de que a baixa eficiência na estimulação de TLR-4 por $B$. parapertussis pode ser uma forma de limitar o acúmulo de neutrófilos e retardar a eliminação mediada por anticorpos, permitindo assim que essa bactéria evite a resposta imune e sobreviva mais tempo no trato respiratório do hospedeiro (WOLFE et al., 2009). No caso de B. pertussis, a PT foi identificada como responsável por esse efeito (KIRIMANJESWARA et al., 2005).

Outros autores mostram que o LPS de B. pertussis foi menos eficiente que o de E. coli na ativação via TLR-4. No entanto, o LPS desta bactéria não ativou o TLR-2 (FEDELE et al., 2007), mas ao contrário, a infecção ativa induziu a sinalização via este receptor (FEDELE et al., 2010). Estes dados nos permite sugerir que a produção de IL-12p40 durante a ativação de macrófagos com esta bactéria envolve sinais emitidos tanto por TLR-4 como o TLR-2.

Em outros modelos, há também evidências de que agonistas de outros receptores como NOD1 e NOD2 podem sinergizar com vários ligantes de TLRs para produção de TNF- $\alpha$ e IL12p40 (LYAKH et al., 2008; TRINCHIERI; SHER, 2007). Assim durante a ativação de macrófagos com estas duas bactérias outros receptores podem participar do controle da síntese destas citocinas.

Muitos dos efeitos biológicos do LPS foram atribuídos a propriedades imunoestimulatórias do lipídio A (MUNFORD; VARLEY, 2006), entretanto, o antígeno O evita que anticorpos induzidos por $B$. pertussis se liguem a $B$. parapertussis permitindo a evasão dessa bactéria da imunidade induzida por B. pertussis (WOLFE et al., 2007).

Ao analisarmos a síntese de IL-12p70 (Figura 12A e 12B), observamos que os M $\phi D M$ ativados com o Ag solúvel ou a infecção ativa com B. pertussis e B. parapertussis não produziram esta citocina de modo significativo.

Segundo Fedele et al. (2008), DCs humanas ativadas com o LPS de B. pertussis e o de B. parapertussis não produziram IL-12p70, apesar de sintetizarem IL-12p40 e outras citocinas (IL-23, IL-10, IL-6 e IL-1 $\beta$ ). Ao contrário, DCs murinas ativadas com B. pertussis viva, morta pelo calor ou sonicada produziram IL-12p70 (HIGGINS et al., 2003). Contudo, 
resultado semelhante ao nosso foi descrito em macrófagos murinos infectados in vitro com Salmonella dublin que produziram IL-12p40, mas não foi detectado IL-12p70 (BOST; CLEMENTS, 1997). Estes dados mostram que a produção de IL-12 pode depender da natureza do antígeno e do tipo celular utilizado. Além disso, a síntese de IL-12p40 e IL-12p70 pode ser regulada por diferentes microrganismos.

Vários aspectos podem estar relacionados à ausência de IL-12p70. Spensieri et al. (2006), mostrou que em DCs humanas o bloqueio da expressão da subunidade p35, que compõe a IL-12p70, se deve ao acúmulo de AMPc intracelular induzido pela ACT de $B$. pertussis, porém esta toxina também está presente em B. parapertussis. Outros dados mostraram que $B$. pertussis viva e inativada pelo calor induziram a transcrição do RNAm da subunidade p40 e p19 por DCs humanas, mas não a transcrição do RNAm da subunidade IL12p35. Portanto, neste modelo, as células não produziram IL-12p70, mas sintetizaram IL-23 formada pelas subunidades p40 e p19 (FEDELE et al., 2005).

Durante a polarização da resposta imune celular, a presença de IL-12p70 é fundamental para a geração de linfócitos Th1 que produzem IFN- $\gamma$ (OPPMANN et al., 2000), enquanto a IL-23 que compartilha a subunidade p40 está associada a ativação de subpopulações Th17 que produzem IL-17 (BARRIE; PLEVY, 2005). Estas subpopulações de linfócitos T são importantes para o controle de infecções.

A produção das subunidades IL-12p40 e p35, necessárias para geração da IL-12p70, podem ser reguladas por diferentes mecanismos. A subunidade p40 é regulada a nível transcricional enquanto a regulação de p35 se dá tanto em nível de transcrição como de tradução (KANG; KIM; KIM, 2005). Além disto, p40 pode formar um homodímero, IL12p80, que se liga ao receptor da subunidade p40 (IL-12R $\beta 1$ ) com alta afinidade e inibe a resposta mediada pela IL-12p70 (HÖLSCHER, 2004). Em células primadas com IFN- $\gamma$ e ativadas com LPS foi comprovado que fatores de transcrição como $\mathrm{NF \kappa B}$ e fatores reguladores de interferon (IRF) contribuem para a indução da expressão dos genes p40 e p35 (GOODRIDGE et al., 2003).

Sabemos que a síntese de IL-12p70 também é regulada por citocinas que favorecem (IFN- $\gamma$ ) ou inibem (IL-10 e TGF- $\beta$ ) sua síntese (KANG; KIM; KIM, 2005). O IFN- $\gamma$ pode ser produzido durante a resposta inata por macrófagos e DCs (SCHRODER et al., 2004), mas durante a infecção com $B$. pertussis, as células NK são as primeiras a fornecer essa citocina (HIGGS et al., 2012). 
Uma vez que $\mathrm{M} \phi \mathrm{DM}$ ativados com $B$. pertussis e $B$. parapertussis não produziram IL12p70, investigamos o papel do IFN- $\gamma$ como sinal molecular para favorecer a síntese de IL12 p70 no modelo em estudo. Observamos que esta citocina foi fundamental para o aumento da produção de IL-12p70 durante a ativação de M $\phi D M$ com ambas as espécies de Bordetella (Figura 13A e 13B).

O IFN- $\gamma$ induz a expressão de fatores reguladores de interferon (IRF) como IRF-8 e IRF-1 em macrófagos que são importantes para a síntese de IL-12 (MASUMI et al., 2002). O IRF-1 é um componente crítico que induz a transcrição do gene da IL-12p35 (LIU et al., 2003). Além disso, o IRF-8 em cooperação com o IRF-1 regula a transcrição do gene da IL12p40 (MASUMI et al., 2002) e da IL-12p35 por se ligarem a locais específicos do promotor destes genes (LIU et al., 2004). Foi descrito que a ACT de B. pertussis inibe a expressão de ambos os IRFs em DCs murinas estimuladas por LPS e IFN- $\gamma$ devido ao aumento de AMPc intracelular, impedindo dessa forma a síntese de IL-12p70. Esta toxina também sinergiza com LPS para induzir IL-10, sendo que MAPKs p38 e ERK1/2 estão envolvidas na síntese desta citocina anti-inflamatória (HICKEY et al., 2008).

Em nosso modelo de estudo (dados não mostrados), assim como em outros (HIGGINS et al., 2003; WOLFE; BUBOLTZ; HARVILL, 2010) durante a ativação ou infecção com $B$. pertussis e $B$. parapertussis houve a produção de IL-10. Isto poderia funcionar como um mecanismo regulatório para reduzir a ativação dos macrófagos, possibilitando a infecção e sobrevivência destas bactérias nos primeiros momentos de contato.

A interação dos PAMPs com os TLRs pode ativar sinalizações intracelulares que incluem MAPKs, PI3K e NFkB (KRISHNAN et al., 2007). Após o estímulo, as proteínas

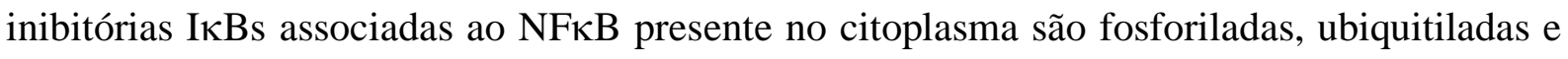
degradadas no proteassomo, permitindo a translocação de $\mathrm{NF \kappa B}$ para o núcleo onde ocorre a regulação da transcrição de diversos genes incluindo o de citocinas inflamatórias (LI; VERMA, 2002). O promotor do gene da subunidade IL-12p40 de humanos e de camundongos contém sítios de ligação para diversos fatores de transcrição incluindo o NFkB (KANG; KIM; KIM, 2005).

Ao investigarmos a contribuição do NFKB na síntese de IL-12p40, após ativação por antígenos de B. pertussis e B. parapertussis, observamos que sua inibição reduziu a a produção desta citocina (Figura 14A e 14B), confirmando a participação do NFkB na produção da IL-12p40. 
Alguns fatores de virulência como FHA de B. pertussis (ABRAMSON; KEDEM; RELMAN, 2008) e moléculas efetoras secretadas pelo sistema de secreção do tipo III de $B$. bronchiseptica podem inibir a ativação de NFKB (YUK et al., 2000), comprometendo a resposta inflamatória e prolongando a sobrevivência deste patógeno no hospedeiro. Por outro lado, foi comprovado que outros componentes destas bactérias como o LPS de B. pertussis e de B. parapertussis podem ativar o NFkB em DCs humanas (FEDELE et al., 2008). Em nosso modelo, houve a ativação do $\mathrm{NF \kappa B}$ em M $\phi \mathrm{DM}$ estimulados com vários componentes destas duas bactérias e a produção de IL-12p40 foi dependente desta ativação.

Outra via envolvida na regulação da produção de citocinas, incluindo a IL-12 é a ativação da cascata de MAPKs (KANG; KIM; KIM, 2005). Ao investigarmos a influência do bloqueio das MAPKs, na síntese de IL-12p40 e p70 após a ativação de macrófagos com os Ags destas bactérias na presença de inibidores farmacológicos seletivos observamos que a síntese de IL-12p40 não envolveu a participação das vias MAPKs p38 e ERK1/2 (Figura 15A e 15B), ao contrário do observado com a IL-12p70, pois a inibição de ambas as vias aumentou significativamente a síntese desta citocina (Figura 16A e 16B). Estes dados são distintos do obtido com DCs humanas infectadas com B. pertussis, onde o pré-tratamento com o inibidor de p38 ou ERK1/2 não restaurou a produção de IL-12p70 (FEDELE et al., 2010). Estas diferenças se devem provavelmente a natureza da APC e o tipo de antígeno utilizado, visto que nós usamos componentes solúveis e não a bactéria integra. Sabemos que distintas APCs podem regular diferentemente a sinalização via MAPKs após a infecção pela mesma bactéria (REISSINGER; SKINNER; YUK, 2005).

Há uma grande diversidade de resposta na regulação de MAPKs por LPS. Foram detectadas diferenças na indução da IL-12 dependendo do tipo celular e das condições experimentais utilizadas (BOUTCHER et al., 2010). Em alguns estudos, a cascata da MAPK p38 pode regular positivamente a produção desta citocina (FENG et al., 1999; LU et al., 1999) ou o contrário (DOBREVA; STANILOVA; MITEVA, 2008; MARRIOTT; CLARKE; DALGLEISH, 2001). Enquanto, a MAPK ERK1/2 pode controlar negativamente (FENG et al., 1999) ou não ter efeito sobre a síntese de IL-12 (BOUTCHER et al., 2010; MARRIOTT; CLARKE; DALGLEISH, 2001). Em nossos experimentos, p38 e ERK1/2 não influenciaram a síntese de IL-12p40, porém aumentaram a produção de p70 nos M $\phi \mathrm{DM}$ estimulados com LPS de E. coli (Figuras 15 e 16). 
Em seguida investigamos se vias de sinalização como PI3K e proteína G poderiam ser utilizadas pelos componentes solúveis de $B$. pertussis e $B$. parapertussis para ativar a produção de IL-p70 pelos M $\phi D M$.

Nossos resultados mostraram que o bloqueio de PI3K favoreceu a produção de IL12p70 pelas células estimuladas com produtos de cada uma das bactérias, isto significa que sinais emitidos por esta via podem impedir a produção desta citocina durante a ativação dos $\mathrm{M} \phi \mathrm{DM}$ com os componentes destas duas espécies de Bordetella (Figura 17A e 17B). Trabalhos usando DCs de camundongos (FUKAO et al., 2002) e monócitos humanos ativados com LPS (MARTIN et al., 2003) mostraram que a inibição de PI3K regula negativamente a produção de IL-12, sugerindo que o efeito se deu sobre a supressão da subunidade IL-12p35. Apesar de termos utilizado Ag solúvel contendo vários outros componentes além do LPS e não termos analisado a expressão de p35 pode ser que o mesmo tenha ocorrido em nosso sistema.

A PT é um importante fator de virulência de B. pertussis que exerce diversos efeitos sobre as células do sistema imune do hospedeiro e possui atividade adjuvante (WANG et al., 2006). Esta toxina favorece o aumento de AMP cíclico intracelular devido à inibição da função da proteína $\mathrm{G} \alpha$ inibitória e dessa maneira pode modular a síntese de IL-12p70 (BRAUN; KELSALL, 2001).

Sabemos que $B$. parapertussis não expressa a PT e não induz a síntese de IL-12p70 (Figura 12). Assim sendo, avaliamos o efeito da adição desta toxina sobre a produção de IL12p70 em M $\phi D M$ estimulados com o Ag desta bactéria.

Nossos resultados mostraram que a adição de PT sobre $\mathrm{M} \phi \mathrm{DM}$ ativados com Ag de $B$. parapertussis aumentou a síntese de IL-12p70, o mesmo ocorrendo quando a toxina foi adicionada junto com LPS. No entanto, a inibição da atividade da proteína Gai pela ação direta da PT não induziu a produção de IL-12p70 (Figura 18). É possível que haja um sinergismo entre PT e os demais componentes bacterianos presentes no Ag solúvel, resultando na ativação de diversos receptores, incluindo o TLR-4, e vias de sinalização intracelular que favoreçam a síntese de IL-12p70. Além disso, as duas subunidades (A e B) dessa toxina podem mediar efeitos biológicos independentemente, como já foi mencionado anteriormente. Estes mecanismos serão explorados futuramente.

Portanto, nossos dados mostraram que a produção de IL-12 em resposta a ativação in vitro de $\mathrm{M} \phi \mathrm{DM}$ com B. pertussis e B. parapertussis apesar de semelhante em alguns aspectos possui diferenças, principalmente naquelas que envolvem a ativação de TLR-4. Além disto, 
várias vias de sinalização podem controlar a síntese de IL-12 durante a resposta imune inata mediada por estas duas bactérias incluindo NFkB, MAPKs, PI3K e proteína Gai. 


\section{CONCLUSÃO}

Nosso trabalho mostrou que a regulação da síntese de IL-12 por M $\phi \mathrm{DM}$ ativados in vitro com $B$. pertussis e $B$. parapertussis envolve os seguintes aspectos:

1) é regulada pela presença de citocinas pró-inflamatórias como TNF- $\alpha$ e IFN- $\gamma$;

2) envolve sinais intracelulares mediados via receptores Toll-Like dependente e independente da molécula adaptadora MyD88;

3) a produção de IL-12p40 foi dependente de TLR-4 apenas durante a ativação dos M $\phi \mathrm{DM}$ com B. pertussis ao contrário do observado com B. parapertussis;

4) a produção de IL-12p40 foi controlada via NFאB, mas foi independente de sinais moleculares via MAPKs p38 e ERK1/2;

5) a síntese de IL-12p70 foi regulada negativamente pelas vias de sinalização MAPKs p38 e ERK1/2, PI3K e proteína Gai. 


\section{REFERÊNCIAS}

ABRAMSON, T.; KEDEM, H.; RELMAN, D. A. Modulation of the NF-kappa B pathway by Bordetella pertussis filamentous hemagglutinin. PLoS One, v. 3, n. 11, p. e3825, 2008.

ARICO, B.; RAPPUOLI, R. Bordetella parapertussis and B. bronchiseptica contain transcriptionally silent pertussis toxin genes. J. Bacteriol., v. 169, p. 2847-2853, 1987.

BABIK, J. M.; ADAMS, E.; TONE, Y.; FAIRCHILD, P. J.; TONE, M.; WALDMANN, H. Expression of Murine IL-12 Is Regulated by Translational Control of the p35 Subunit. The Journal of Immunology, v. 162, p. 4069-4078, 1999.

BADU, M. M.; BHARGAVI, J.; SAUND, R. S.; SINGH, K. Virulence factors of Bordetella pertussis. Current Science, v. 12, p. 1512-1522, 2001.

BANUS, H. A.; VANDEBRIEL, R. J.; RUITER, H.; DORMANS, J. A. M. A.; NAGELKERKE, N. J.; MOOI, F. R.; HOEBEE, B.; VAN KRANEN, H. J.; KIMMANI, T. G. Host Genetics of Bordetella pertussis Infection in Mice: Significance of Toll-Like Receptor 4 in Genetic Susceptibility and Pathobiology. Infect. Immun., v. 74, n. 5, p. 25962605, 2006.

BARRA, M. Adultos são as principais fontes de transmissão da coqueluche a bebês. G1, sept 2011. Disponível em: <http://g1.globo.com/ciencia-e-saude/noticia/2011/09/adultos-saoprincipais-fontes-de-transmissao-da-coqueluche-bebes. html>. Acesso em: 20 fev. 2012.

BARRIE, A. M.; PLEVY, S. E. The interleukin-12 family of cytokines: Therapeutic targets for inflammatory disease mediation. Clinical and Applied Immunology Reviews, v. 5, p. 225-240, 2005.

BASSINET, L.; GUEIRARD, P.; MAITRE, B.; HOUSSET, B.; GOUNON, P.; GUISO,N. Role of Adhesins and Toxins in Invasion of Human Tracheal Epithelial Cells by Bordetella pertussis. Infection and Immunity, v. 68, n. 4, p. 1934-1941, 2000.

BLACK, R. E.; COUSENS, S.; JOHNSON, H. L.; LAWN, J. E.; RUDAN, I.; BASSANI, D. G.; JHA, P.; CAMPBELL, H.; WALKER, C. F.; CIBULSKIS, R.; EISELE, T.; LIU, L.; MATHERS, C. Global, regional, and national causes of child mortality in 2008: a systematic analysis. Lancet, v. 375, p. 1969-1987, 2010.

BOLTZ-NITULESCU, G.; WILTSCHKE, C.; HOLZINGER, C.; FELLINGER, A.; SHERNER, O.; GESSI, A.; FÖRSTER, O. Differentiation of rat bone marrow cells into macrophages under the influence of mouse L929 cell supernatant. J. Leukocyte Biology, v. 41, p. 83-91, 1987.

BONIZZI, G.; KARIN, M. The two NF- $\kappa \mathrm{B}$ activation pathways and their role in innate and adaptive immunity. Trends Immunol., v. 25, n. 6, p. 280-288, 2004.

"De acordo com:

ASSOCIAÇÃO BRASILEIRA DE NORMAS TÉCNICAS. NBR 6023: informação e documentação: referências: elaboração. Rio de Janeiro, 2002. 
BOST, K. L.; CLEMENTS, J. D. Intracellular Salmonella dublin induces substantial secretion of the 40-kilodalton subunit of interleukin-12 (IL-12) but minimal secretion of IL-12 as a 70kilodalton protein in murine macrophages. Infect Immun., v. 65, n. 8, p. 3186-3192, 1997.

BOUCHER, J. G.; PARATO, K. A.; FRAPPIER, F.; FAIRMAN, P.; BUSCA, A.; SAXENA, M.; BLAHOIANU, M. A.; MA, W.; GAJANAYAKA, N.; PARKS, R. J.; KUMAR, A.; ANGEL, J. B. Disparate regulation of LPS-induced MAPK signaling and IL12 p40 expression between different myeloid cell types with and without HIV infection. Viral Immunol., v. 23, n. 1; p. 17-28, 2010.

BRASIL. Ministério da Saúde. Guia de Vigilância Epidemiológica/Ministério da Saúde, Secretaria de Vigilância em Saúde. 6. ed. Brasília, 2005. (Série A. Normas e Manuais Técnicos).

BRASIL. Ministério da Saúde. Guia de Vigilância Epidemiológica/Ministério da Saúde, Secretaria de Vigilância em Saúde. 7. ed. Brasília, 2009. (Série A. Normas e Manuais Técnicos).

BRAUN, M. C.; KELSALL, B. L. Regulation of interleukin-12 production by G-proteincoupled receptors. Microbes Infect., v. 3, n. 2, p. 99-107, 2001.

BRICKS, L. F. Vacinas acelulares pertussis para adolescentes e adultos: revisão. Pediatria, v. 29, n. 3, p. 208-215, 2007.

BURNS, V. C.; PISHKO, E. J.; PRESTON, A.; MASKELL, D. J.; HARVILLI, E. T. Role of Bordetella $\mathrm{O}$ Antigen in Respiratory Tract Infection. Infection and Immunity, v. 71, n. 1, p. 86-94, 2003.

CANTHABOO, C.; XING, D.; WEI, X. Q.; CORBEL, M. J. Investigation of Role of Nitric Oxide in Protection from Bordetella pertussisRespiratory Challenge. Infect Immun., v. 70, n. 2, p. 679-684, 2002.

CARBONETTI, N. H. Immunomodulation in the pathogenesis of Bordetella pertussis infection and disease. Current Opinion in Pharmacology, v. 7, p. 272-278, 2007.

CARBOnETTI, N. H.; ARTAMONOVA, G. V.; VAN ROOIJEN, N.; AYALA, V. I. Pertussis toxin targets airway macrophages to promote Bordetella pertussis infection of the respiratory tract. Infect. Immun., v. 75, p. 1713-1720, 2007.

CARBONETTI, N. H. Pertussis toxin and adenylate cyclase toxin: key virulence factors of Bordetella pertussis and cell biology tools. Future Microbiol., v. 5, p. 455-469, 2010.

CAROFF, M.; KARIBIAN, D.; CAVAILLON, J. M.; HAEFFNER-CAVAILLON, H. Structural and functional analyses of bacterial lipopolysaccharides. Microbes and Infection, v. 4, p. 915-926, 2002.

CARVALHO, A. P.; PEREIRA, E. M. Acellular pertussis vaccine for adolescents. J Pediatr., v. 82, n. 3, p. S15-24, 2006. 
CENTER FOR DISEASE CONTROL AND PREVENTION. Pertussis Epidemic Washington, 2012. Morbidity and Mortality Weekly Report, v. 61, n. 28, p. 517-543, 2012.

CHILTON, P. M.; EMBRY, C. A.; MITCHELL, T. C. Effects of Differences in Lipid A Structure on TLR4 Pro-Inflammatory Signaling and Inflammasome Activation. Front Immunol., v. 154, n. 3, p. 1-8, 2012.

COBB, M. H.; GOLDSMITH, E. J. How MAP kinases are regulated. J. Biol. Chem., v. 270, n. 25, p. 14843-14846, 1995.

COORDENAÇÃO DE VIGILÂNCIA EM SAÚDE (COVISA). Coqueluche Vigilância Epidemiológica e Triagem Diagnóstica. Boletim informativo, São Paulo, n. 2, 2009.

CREMER, T. J.; BUTCHAR, J. P.; TRIDANDAPANI, S. Francisella Subverts Innate Immune Signaling: Focus On PI3K/Akt. Front Microbiol., v. 2, n. 13, p. 1-6, 2011.

CULlinANE, L. C.; ALLEY, M. R.; MARSHALl, R. B.; MANKTELOW, B. W. Bordetella parapertussis from lambs. N. Z. Vet. J., v. 35, n. 10, p. 175, 1987.

CUMMINGS, C. A.; BRINIG, M. M.; LEPP, P. W.; VAN DE PÁS, S.; RELMAN D. A. Bordetella species are distinguished by patterns of substantial gene loss and host adaptation. J. Bacteriol., v. 186, n. 5, p. 1484-1492, 2004.

DAVID, S.; VAN FURTH, R.; MOOI, F. R. Efficacies of whole cell and acellular pertussis vaccines against Bordetella parapertussis in a mouse model. Vaccine, v. 22, n. 15-16, p. 1892-1898, 2004.

DEANE, J. A.; FRUMAN, D. A. Phosphoinositide 3-kinase: diverse roles in immune cell activation. Annu. Rev. Immunol., v. 22, p. 563-598, 2004.

DIAS, W. O.; LEITE, L. L.; HORTON, D. S. P. Q.; SAKAUCHI, M. A.; KUBRUSLY, F. S.; FURUYAMA, N.; NASCIMENTO, I. P.; QUINTILIO, W.; HIGASHI, H. G.; RAW, I. New approaches in pertussis vaccines for developing countries. Communicating Current Research and Educational Topics and Trends in Applied Microbiology, p. 668-672, 2007.

DOBREVA, Z. G.; STANILOVA, S. A.; MITEVA, L. D. Differences in the inducible gene expression and protein production of IL-12p40, IL-12p70 and IL-23: involvement of p38 and JNK kinase pathways. Cytokine, v. 43, p. 76-82, 2008.

FEDELE, G.; STEFANELLI, P.; SPENCIERI, F.; FAZIO, C.; MASTRANTONIO, P.; AUSIELLO, C. M. Bordetella pertussis-Infected Human Monocyte-Derived Dendritic Cells Undergo Maturation and Induce Th1 Polarization and Interleukin-23 Expression. Infection and Immunity, v. 73, n. 3, p. 1590-1597, 2005.

FEDELE, G.; CELESTINO, I.; SPENSIERI, F.; FRASCA, L.; NASSO, M.; WATANABE, M.; REMOLI, M. E.; COCCIA, E. M.; ALTIERI, F.; AUSIELlO, C. M. Lipooligosaccharide from Bordetella pertussis induces mature human monocyte-derived dendritic cells and drives a Th2 biased response. Microbes Infec., v. 9, n. 7, p. 855-863, 2007.

FEDELE, G.; NASSO, M.; SPENSIERI, F.; PALAZZO, R.; FRASCA, L.; WATANABE, M.; AUSIELLO, C. M. Lipopolysaccharides from Bordetella pertussis and Bordetella 
parapertussis differently modulate human dendritic cell functions resulting in divergent prevalence of Th17-polarized responses. J. Immunol., v. 181, n. 1, p. 208-216, 2008.

FEDELE, G.; SPENSIERI, F.; PALAZZO, R.; NASSO, M.; CHEUNG, G. Y.; COOTE, J. G.; AUSIELLO, C. M. Bordetella pertussis commits human dendritic cells to promote a Th1/Th17 response through the activity of adenylate cyclase toxin and MAPK-pathways. PLoS One, v. 5, n. 1, p. e8734, 2010.

FENG, G.; GOODRIDGE, H. S.; HARNETT, M. M.; WEI, X.; NIKOLAEV, A. V.; HIGSON, A. P.; LIEW, F. Extracellular Signal-Related Kinase (ERK) and p38 MitogenActivated Protein (MAP) Kinases Differentially Regulate the Lipopolysaccharide-Mediated Induction of Inducible Nitric Oxide Synthase and IL-12 in Macrophages: Leishmania Phosphoglycans Subvert Macrophage IL-12 Production by Targeting ERK MAP Kinase. J. Immunol., v. 163, p. 6403-6412, 1999.

FENG, C. G.; SCANGA, C. A.; COLlAZO-CUSTODIO, C. M.; CHEEVER, A. W.; HIENY, S.; CASPAR, P.; SHER, A. Mice lacking myeloid differentiation factor 88 display profound defects in host resistance and immune responses to Mycobacterium avium infection not exhibited by Toll-like receptor 2 (TLR2) and TLR4-deficient animals. J. Immunol., v. 171, n. 9, p. 4758-4764, 2003.

FENNELLY, N. K.; SISTI, F.; HIGGINS, S. C.; ROSS, P. J.; VAN DER HEIDE, H.; MOOI, F. R.; BOYD, A.; MILLS, K. H. Bordetella pertussis expresses a functional type III secretion system that subverts protective innate and adaptive immune responses. Infect Immun., v. 76, n. 3, p. 1257-1266, 2008.

FLESCH, I. E.; HESS, J. H.; HUANG, M.; AGUET, M.; ROTHE, J.; BLUETHMANN, H.; KAUFMANN, S. H. Early interleukin 12 production by macrophages in response to mycobacterial infection depends on interferon $\gamma$ and tumor necrosis factor $\alpha$. J. Exp. Med., v. 181, p. 1615-1621, 1995.

FORSYTH, K. D.; WIRSING VON KONING, C. H.; TAN, T.; CARO, J.; PLOTKIN, S. Pervention of pertussis: Recommendation derived from the second global pertussis initiative roundtable meeting. Vacine, v. 25, p. 2634-2642, 2007.

FUJIHARA, M.; MUROI, M.; TANAMOTO, K.; SUZUKI, T.; AZUMA, H.; IKEDA, H. Molecular mechanisms of macrophage activation and desativation by lipopolysaccharide: roles of the receptor complex. Pharmacology \& Therapeutics, v. 100, p. 171-194, 2003.

FUKAO, T.; TANABE, M.; TERAUCHI, Y.; OTA, T.; MATSUDA, S.; ASANO, T.; KADOWAKI, T.; TAKEUCHI, T.; KOYASU, S. PI3K-mediated negative feedback regulation of IL-12 production in DCs. Nat. Immunol., v. 3, p. 875-881, 2002.

GEISSMANN, F.; MANZ, M. G.; JUNG, S.; SIEWEKE, M. H.; MERAD, M.; LEY, K. Development of Monocytes, Macrophages, and Dendritic Cells. Science, v. 327, p. 656-661, 2010.

GERLACH, G.; VON WINTZINGERODE, F.; MIDDENDORF, B.; GROSS, R. Evolutionary trends in the genus Bordetella. Microbes and Infection, v. 3, p. 61-72, 2001. 
GERSUK, G.; HIRAOKA, A.; MARR, K. A. Human monocytes differentiate into macrophages under the influence of human KPB-M15 conditioned medium. J. Immunol. Methods, v. 299, n. 1-2, p. 99-106, 2004.

GHOSH, S.; MAY, M. J.; KOPP, E. B. NF- $\kappa$ B and rel proteins: evolutionary conserved mediators of immune responses. Annu. Rev. Immunol., v. 16, p. 225-260, 1998.

GIRARD, R. PEDRON, T.; UEMATSU, S.; BALLOY, V.; CHIGNARD, M.; AKIRA, S.; CHABY, R. Lipopolysaccharides from Legionella and Rhizobium stimulate mouse bone marrow granulocytes via Toll like receptor 2. J. Cell Science, v. 116, p. 293-302, 2003.

GOEBEL, E. M.; WOLFE, D. N.; ELDER, K.; STIBITZ, S.; HARVILL, E. T. O Antigen Protects Bordetella parapertussis from Complement. Infection and Immunity, v. 76, n. 4, p. 1774-1780, 2008.

GOODRIDGE, H. S.; HARNETT, W.; LIEW, F. Y.; HARNETT, M. M. Differential regulation of interleukin-12 p40 and p35 induction via ERK MITOGEN-activated protein kinase -dependent and independent mechanisms and the implications for bioative IL-12 and IL-23 responses. Immunology, v. 109, p. 415-425, 2003.

GOUW, D.; DIAVATOPOUlOS, D. A.; BOOTSMA, H. J.; HERMANS, P. W.; MOOI, F. R. Pertussis: a matter of immune modulation. FEMS Microbiol Rev., v. 35, n. 3, p. 441-474, 2011.

GRAY, M.; SZABO, G.; OTERO, A. S. A.; GRAY, L.; HEWLETT, E. Distinct mechanisms for K efflux, intoxication, and hemolysis by Bordetella pertussis AC toxin. J. Biol. Chem., v. 273, p. 18260-18267, 1998.

GUEIRARD, P.; DRUILHE, A.; PRETOLANI, M.; N. GUISO. Role of adenylate cyclasehemolysin in alveolar macrophage apoptosis during Bordetella pertussis infection in vivo. Infect. Immun., v. 66, p. 1718-1725, 1998.

GUISO, N.; BERBERS, G.; FRY, N. K.; HE, Q.; RIFFELMANN, M.; WIRSING VON KÖNIG, C. H.; EU PERTSTRAIN GROUP. What to do and what not to do in serological diagnosis of pertussis: recommendations from EU reference laboratories. Eur J Clin Microbiol Infect Dis., v. 30, n. 3, p. 307-312, 2011.

HAUSCHILDT, S.; BRABETZ, W.; SCHROMM, A. B.; HAMANN, L.; ZABEL, P.; RIETSCHEL, E. T.; MÜLLER-LOENNIES, S. Structure and Activity of Endotoxins. In: Bacterial Protein Toxins. Springer Berlin Heidelberg; 2000. Cap. 27, p. 619-667. (Handbook of Experimental Pharmacology, 145).

HE, J.; GURUNATHAN, S.; IWASAKI, A.; ASH-SHAHEED, B.; KELSALL, B. L. Primary Role for Gi Protein Signaling in the Regulation of Interleukin 12 Production and the Induction of T Helper Cell Type 1 Responses. J. Exp. Med., v. 191, n. 9, p. 1605-1610, 2000.

HELLWIG, S. M.; VAN SPRIEL, A. B.; SCHELLEKENS, J. F.; MOOI, F. R.; VAN DE WINKEL, J. G. Immunoglobulin A-mediated protection against Bordetella pertussis infection. Infect Immun., v. 69, n. 8, p. 4846-4850, 2001. 
HIGGINS, S. C.; LAVELLE, E. C.; MCCANN, C.; KEOGH, B.; MCNEELA, E.; BYRNE, P.; O'GORMAN, B.; JARNICKI, A.; MCGUIRK, P.; MILLS, K. H. Toll-like receptor 4mediated innate IL-10 activates antigen-specific regulatory $\mathrm{T}$ cells and confers resistance to Bordetella pertussis by inhibiting inflammatory pathology. J. Immunol., v. 171, n. 6, p. 3119-3127, 2003.

HIGGINS, S. C.; JARNICKI, A. G.; LAVELlE, E. C.; MILLS, K. H. TLR4 mediates vaccine-induced protective cellular immunity to Bordetella pertussis: role of IL-17-producing T cells. J. Immunol., v. 177, p. 7980- 7989, 2006.

HIGGS, R.; HIGGINS, S. C.; ROSS, P. J.; MILLS, K. H. Immunity to the respiratory pathogen Bordetella pertussis. Mucosal Immunol., v. 5, n. 5, p. 485-500, 2012.

HOEPELMAN, A. I. M.; TUOMANEN, E. I. Consequences of Microbial Attachment: Directing Host Cell Functions with Adhesins. Infect.Immun., v. 60, n. 5, p. 1729-1733, 1992.

HÖLSCHER, C. The power of combinatorial immunology: IL-12 and IL-12-related dimeric cytokines in infectious diseases. Med. Microbiol. Immunol., v. 193, p. 1-17, 2004.

HRISTOV, A. C.; AUWAERTER, P. G.; ROMAGNOLI, M.; CARROLL, K. C.Bordetella hinzii septicemia in association with Epstein-Barr virus viremia and an Epstein-Barr virusassociated diffuse large B-cell lymphoma. Diagnostic Microbiology and Infectious Disease, v. 61, p. 484-486, 2008.

JENKINSON, D. Duration of effectiveness of pertussis vaccine: evidence from 10 years community study. Br. Med. J., v. 296, p. 612-614, 1988.

JOHN, C. M.; LIU, M.; JARVIS, G. A. Profiles of structural heterogeneity in native lipooligosaccharides of Neisseria and cytokine induction. J Lipid Res., v. 50, n. 3, p. 424438, 2009.

JONES, B.; HELDWEIN, K.; MEANS, T.; SAUKKONEN, J.; FENTON, M. Differential roles of toll-like receptors in the elicitation of proinflammatory responses by macrophages. Ann Rheum Dis., v. 60, n. 3, p. 6-12, 2001.

KADOWAKI, T.; SHIMADA, M.; INAGAWA, H.; KOHCHI, C.; HIRASHIMA, M.; SOMA, G. Reconsideration of macrophage and dendritic cell classification. Anticancer Res., v. 32, n. 6, p. 2257-2261, 2012.

KANG, B. Y.; KIM, E.; KIM, T. S. Regulatory mechanisms and their therapeutic implications of interleukin-12 production in immune cells. Cellular Signalling, v. 17, p. 665673, 2005.

KATADA, T.; TAMURA, M.; UI, M. The A protomer of islet-activating protein, pertussis toxin, as an active peptide catalyzing ADP-ribosylation of a membrane protein. Arch Biochem Biophys., v. 224, p. 290-298, 1983.

KAWAI, T; AKIRA, S. TLR signaling. Cell Death Differ., v. 13, n. 5, p. 816-825, 2006. 
KERR, J. R.; MATTHEWS, R. C. Bordetella pertussis infection: pathogenesis, diagnosis, management, and the role of protective immunity. Eur. J. Clin. Microbiol. Infect Dis., v. 19, p. 77-88, 2000.

KERSTERS, K.; HINZ, K. H.; HERTLE, A.; SEGERS, P.; LIEVENS, A.; SIEGMANN, O.; DE LEY, J. Bordetella avium sp. nov., isolated from the respiratory tracts of turkeys and other birds. Int. J. Syst. Bacteriol., v 34, p. 56-70, 1984.

KHELEF, N.; ZYCHLINSKY, A.; GUISO, N. Bordetella pertussis induces apoptosis in macrophages: role of adenylate cyclase-hemolysin. Infect. Immun., v. 61, p. 4064-4071, 1993.

KHELEF, N.; DANVE, B.; QUENTIN-MILLET, M. J.; GUISO, N. Bordetella pertussis and Bordetella parapertussis: two immunologically distinc species. Infect. Immun., v. 161, n. 2, p. 486-490, 1993.

KIM, S. H.; KIM, J.; SHARMA, R. P. Inhibition of p38 and ERK MAP kinases blocks endotoxin-induced nitric oxide production and differentially modulates cytokine expression. Pharmacological Research, v. 49, n. 5, p. 433-439, 2004.

KINNEAR, S. M.; MARQUES, R. R.; CARBONETTI, N. Differential Regulation of BvgActivated Virulence Factors Plays a Role in Bordetella pertussis Pathogenicity. Infect. Immun., v. 69, n. 4, p. 1983-1993, 2001.

KIRIMANJESWARA, G. S.; MANN, P. B.; HARVILL, E. T. Role of antibodies in immunity to Bordetella infections. Infect Immun., v. 71, n. 4, p. 1719-1724, 2003.

KIRIMANJESWARA, G. S.; AGOSTO, L. M.; KENNETT, M. J.; BJORNSTAD, O. N.; HARVILL, E. T. Pertussis toxin inhibits neutrophil recruitment to delay antibodymediated clearance of Bordetella pertussis. J Clin Invest., v. 115, n. 12, p. 3594-3601, 2005.

KO, K. S.; PECK, K. R.; OH, W. S.; LEE, N. Y.; LEE, J. H.; SONG, J-H. New Species of Bordetella, Bordetella ansorpii sp. nov., Isolated from the Purulent Exudate of an Epidermal Cyst. J. Clin. Microb., v. 43, n. 5, p. 2516-2519, 2005.

KOH, Y. S.; KOO, J. E.; BISWAS, A.; KOBAYASHI, K. S. MyD88-dependent signaling contributes to host defense against ehrlichial infection. PLoS One, v. 5, n.7, p. 1-11, 2010.

KORGENSKI, E. K.; DALY, J. A. Surveillance and detection of erythromycin resistance in Bordetella pertussis isolates recovered from a pediatric population in the Intermountain West region of the United States. J. Clin. Microbiol., v. 35, p. 2989-2991, 1997.

KRISHNAN, J.; SELVARAJOO, K.; TSUCHIYA, M.; LEE, G.; CHOI, S. Toll-like receptor signal transduction. Exp Mol Med., v. 39, n. 4, p. 421-438, 2007.

KUMAR, H.; KAWAI, T.; AKIRA, S. Pathogen recognition in the innate immune response. Biochem. J., v. 420, p. 1-16, 2009.

KUMAR, H.; KAWAI, T.; AKIRA, S. Pathogen recognition by the innate immune system. Int Rev Immunol., v. 30, n. 1, p. 16-34, 2011. 
LABOISSIÈRE, P. Grávidas serão vacinadas contra coqueluche a partir do segundo semestre deste ano. Agência Brasil, feb 2013. Disponível em: <http://agenciabrasil.ebc.com.br/notícia/ 2013-02-19/grávidas-serao-vacinadas-contra-coqueluche-partir-do-segundo-semestre-desteano>. Acesso em: 02 maio 2013.

LADANT, D.; ULLMANN, A. Bordetella pertussis adenylate cyclase: A toxin with multiple talents. Trends Microbiol., v. 7, p. 172-176, 1999.

LAMBERTI, Y. A.; HAYES, J. A.; VIDAKOVICS, M. L. P.; HARVILL, E. T.; RODRIGUEZ, M. E. Intracellular Trafficking of Bordetella pertussis in Human Macrophages. Infect Immun., v. 78, n. 3, p. 907-913, 2010.

LAMONT, A. G.; ADORINI, L. IL-12: a key cytokine in immune regulation. Immunol. Today, v. 17, p. 214-217, 1996.

LANGLEY, J. M.; HALPERIN, S. A.; BOUCHER, F. D.; SMITH, B. Azithromycin is as effective as and better tolerated than erythromycin estolate for the treatment of pertussis. Pediatrics, v. 114, p. 96-101, 2004.

LEBEL, M. H.; MEHRA, S. Efficacy and safety of clarithromycin versus erythromycin for the treatment of pertussis: a prospective, randomized, single blind trial. Pediatr. Infect. Dis. J., v. 20, p. 1149-1154, 2001.

LIPHALUS, B. L.; GONÇALVES, M. I. C.; CARVALHANAS, T. R. M. P. Coqueluche: epidemiologia e controle: Pertussis: epidemiology and control. Boletim Epidemiológico Paulista, v. 53, n. 5, may 2008. Disponível em: <http://www.cve.saude.sp.gov.br/agencia/ bepa53_coqueluche.htm>. Acesso em: 09 abr. 2011.

LIU, J.; CAO, S.; HERMAN, L. M.; MA, X. Differential Regulation of Interleukin (IL)-12 p35 and p40 Gene Expression and Interferon (IFN)- $\gamma$-primed IL-12 Production by IFN Regulatory Factor 1. J. Exp. Med., v. 198, n. 8, p. 1265-1276, 2003.

LIU, J.; GUAN, X.; TAMURA, T.; OZATO, K.; MA, X. Synergistic activation of interleukin-12p35 gene transcription by interferon regulatory factor-1 and interferon consensus sequence-binding protein. J. Biol. Chem., v. 279, n. 53, p. 55609-55617, 2004.

LIU, Y.; SHEPHERD, E. G.; NELIN, L. D. MAPK phosphatases regulating the immune response. Nat. Rev. Immunol., v. 7, n. 3, p. 202-212, 2007.

LOCHT, C. Molecular aspects of Bordetella pertussis pathogenesis. Internatl Microbiol., v. 2, p. 137-144, 1999.

LOCHT, C.; ANTOINE, R.; JACOB-DUBUISSON, F. Bordetella pertussis, molecular pathogenesis under multiple aspects. Current Opinion in Microbiology, v. 4, p. 82-89, 2001.

LOCHT, C.; COUTTE, L.; MIELCAREK, N. The ins and outs of pertussis toxin. FEBS Journal, v. 278, p. 4668-4682, 2011. 
LU FERNANDES COMUNICAÇÃO E IMPRENSA. Aumento do número de casos de coqueluche no Brasil e no mundo motiva campanha Internacional contra a doença. Disponível em:< http://www.lufernandes.com.br/2010/ultimas-noticias/aumento-do-numerode-casos-de-coqueluche-no-brasil-e-no-mundo-motiva-campanha-internacional-contra-adoenca/>. Acesso em: 15 fev. 2013.

LU, H-T.; YANG, D. D.; WYSK, E. G.; MELLMAN, I.; DAVIS, R. J.; FLAVELL, R. A. Defective IL-12 production in mitogen-activated protein (MAP) kinase kinase 3 (Mkk3)deficient mice.The EMBO Journal, v. 18, n. 7, p. 1845-1857, 1999.

LUKER, K. E.; TCOLLIER, J. L.; KOLODZIEJ, E. W.; MARSHALL, G. R.; GOLDMANN, W. E. Bordetella pertussis tracheal cytotoxin and other muramyl peptides: distinct structure-activity relationships for respiratory epithelial cytopathology. Proc. Natl Acad Sci USA., v. 90, n. 6, p. 2365-2369, 1993.

LUZ, P. M.; CODEÇO, C. T.; WERNECK, G. L. A reemergência da coqueluche em países desenvolvidos: um problema também para o Brasil? Cad. Saúde Pública, v. 19, n. 4, p. 12091213, 2003.

LYAKH, L.; TRINCHIERI, G.; PROVEZZA, L.; CARRA, G.; GEROSA, F. Regulation of interleukin-12/interleukin-23 production and the T-helper 17 response in humans. Immunol Rev., v. 226, p. 112-131, 2008.

MA, X.; SUN, J.; PAPASAVVAS, E.; RIEMANN, H.; ROBERTSON, S.; MARSHALL, J.; BAILER, R. T.; MOORE, A.; DONNELLY, R. P.; TRINCHIERI, G.; MONTANER, L.J. Inhibition of IL-12 production in human monocyte-derived macrophages by TNF. $\mathbf{J}$. Immunol., v. 164, n. 4, p. 1722-1729, 2000.

MAHON, B. P.; RYAN, M.; GRIFFIN, F.; MILLS, K. H. G. IL-12 is produced by live or killed Bordetella pertussis and enhances the efficacy of an acellular pertussis vaccine by promoting induction of Th1 cells. Infect. Immun., v. 64, p. 5295-5301, 1996.

MANGMOOL, S.; KUROSE, H. Gi/o Protein-Dependent and -Independent Actions of Pertussis Toxin (PTX). Toxins, v. 3, p. 884-899, 2011.

MANN. P. B.; WOLFE, D.; LATZ, E.; GOLENBOCK, D.; PRESTON, A; HARVILL, E.T. Comparative Toll-Like Receptor 4-Mediated Innate Host Defense to Bordetella infection. Infect. Immun., v. 73, n. 12, p. 8144-8152, 2005.

MARCHANT, J.; CHANG, A. Managing pertussis in adults. Aust Prescr., v. 32, p. 36-38, 2009.

MARR, N.; HAJJAR, A. M.; SHAH, N, R.; NOVIKOV, A.; YAM, C. S.; CAROFF, M.; FERNANDEZ, R. C. Substitution of the Bordetella pertussis Lipid A Phosphate Groups with Glucosamine Is Required for Robust NF- $\kappa$ B Activation and Release of Proinflammatory Cytokines in Cells Expressing Human but Not Murine Toll-Like Receptor 4-MD-2-CD14. Infect. Immun., v. 78, n. 5, p. 2060-2069, 2010. 
MARRIOTT, J. B.; CLARKE, I. A.; DALGLEISH, A. G. Inhibition of p38 MAP kinase during cellular activation results in IFN-g-dependent augmentation of IL-12 production by human monocytes/macrophages. Clin. Exp. Immunol., v. 125, p. 64 -70, 2001.

MARTIN, M.; SCHIFFERLE, R. E.; CUESTA, N.; VOGEL, S. N.; KATZ, J.; MICHALEK, S. M. Role of the Phosphatidylinositol 3 Kinase-Akt Pathway in the Regulation of IL-10 and IL-12 by Porphyromonas gingivalis Lipopolysaccharide. J. Immunol., v. 171, p. 717-725, 2003.

MARTINS, J. F. Estudo sobre a reação inflamatória produzida pela vacina contra a difteria, o tétano e a coqueluche (DTP) em camundongos. 2006. 101 f. Dissertação (Mestrado em Vigilância Sanitária) - Instituto Nacional de Controle de Qualidade em Saúde, Fundação Oswaldo Cruz, Rio de Janeiro, 2008.

MARZOUQI, I.; RICHMOND, P.; FRY, S.; WETHERALL, J.; MUKKUR, T. Development of improved vaccines against whooping cough Current status. Human Vaccines, v. 6, n. 7, p. 543-553, 2010.

MASTRANTONIO, P.; STEFANELLI, P.; GIULIANO, M.; ROJAS, Y. H.; ATTI, M. D. C.; ANEMONA, A.; TOZZI, A. E. Bordetella parapertussis Infection in Children: Epidemiology, Clinical Symptoms, and Molecular Characteristics of Isolates. J. Clinical Microbiology, v. 36, n. 4, p. 999-1002, 1998.

MASUMI, A.; TAMAOKI, S.; WANG, I. M.; OZATO, K.; KOMURO, K. IRF-8/ICSBP and IRF-1 cooperatively stimulate mouse IL-12 promoter activity in macrophages. FEBS Lett., v. 531, n. 2, p. 348-353, 2002.

MATOO, S.; CHERRY, J. D. Molecular Pathogenesis, Epidemiology, and Clinical Manifestations of Respiratory Infections Due to Bordetella pertussis and Other Bordetella Subspecies. Clinical Microbiology Reviews, v. 18, n. 2, p. 326-382, 2005.

MILLS, K. H. G. Immunity to Bordetella pertussis. Microbes Infect., v. 3, p. 655-677, 2001.

MIYAKE, K. Innate recognition of lipopolysaccharide by Toll-like receptor 4-MD-2. Trends Microbiol., v. 12, n. 4, p. 186-192, 2004.

MOGENSEN, T. H. Pathogen Recognition and Inflammatory Signaling in Innate Immune Defenses. Clin. Microbiol. Rev., v. 22, n. 2, p. 240-273, 2009.

MUNFORD, R. S.; VARLEY, A. W. Shield as signal: lipopolysaccharides and the evolution of immunity to gram-negative bacteria. PLoS Pathog., v. 2, n. 6, p. e67, 2006.

MURPHY, T. L.; CLEVELAND, M. G.; KULESZA, P.; MAGRAM, J.; MURPHY, K. M. Regulation of Interleukin 12 p40 Expression through an NF-kB Half-Site. Molecular and Cellular Biology, v. 15, n. 10, p. 5258-5267, 1995.

MURRAY, P. R.; ROSENTHAL, K. S.; KOBAYASHY, G. S.; PFALLER, M. A. Microbiologia Médica. 4. ed. Rio de Janeiro: Guanabara Koogan, 2004. 762 p. 
MURRAY, P. J.; WYNN, T. Protective and pathogenic functions of macrophage subsets. Nat. Rev. Immun., v. 11, p. 723-737, 2011.

NASSO, M.; FEDELE, $\quad$ G.; SPENSIERI, F.; PALAZZO, R.; COSTANTINO, P.; RAPPUOLI, R.; AUSIELLO, C. M. Genetically detoxified pertussis toxin induces Th1/Th17 immune response through MAPKs and IL-10-dependent mechanisms. J. Immunol., v. 183, n. 3, p. 1892-1899, 2009.

NAGAMATSU, K.; KUWAE, A.; KONAKA, T.; NAGAI， S.; YOSHIDA, S.; EGUCHI, M.; WATANABE, M.; MIMURO, H.; KOYASU, S.; ABE, A. Bordetella evades the host immune system by inducing IL-10 through a type III effector, BopN. J. Exp. Med., v. 206, n. 13, p. 3063-3088, 2009.

NETEA, M. G. Toll-like receptors and the host defense against microbial pathogens: bringing specificity to the innate-immune system. J. Leukoc. Biol., v. 75, p. 749-755, 2004.

NIGG, A. P.; ZAHN, S.; RÜCKERL, D.; HÖLSCHER, C.; YOSHIMOTO, T.; EHRCHEN, J. M.; WÖLBING, F.; UDEY, M. C.; VON STEBUT, E. Dendritic Cell-Derived IL-12p40 Homodimer Contributes to Susceptibility in Cutaneous Leishmaniasis in BALB/c Mice. The Journal of Immunology, v. 178, p. 7251-7258, 2007.

PARKHILL, J.; SEBAIHIA, M.; PRESTON, A.; MURPHY, L. D.; THOMSON, N.; HARRIS, D. E.; HOLDEN, M. T. G.; CHURCHER, C.; BENTLEY, S. D.; MUNGALL, K. L.; CERDEÑO-TÁRRAGA, A. M.; TEMPLE, L.; JAMES, K.; HARRIS, B.; QUAIL, M. A.; ACHTMAN, M.; ATKIN, R.; BAKER, S.; BASHAM, D.; BASON, N.; CHEREVACH, I.; CHILLINGWORTH, T.; COLLINS, M.; CRONIN, A.; DAVIS, P.; DOGGETT, J.; FELTWELL, T.; GOBLE, A.; HAMLIN, N.; HAUSER, H.; HOLROYD, S.; JAGELS, K.; LEATHER, S.; MOULE, S.; NORBERCZAK, H.; O'NEIL, S.; ORMOND, D.; PRICE, C.; RABBINOWITSCH, E.; RUTTER, S.; SANDER, M.; SAUNDERS, D.; SEEGER, K.; SHARP, S.; SIMMONDS, M.; SKELTON, J.; SQUARES, R.; SQUARES, S.; STEVENS, K.; UNWIN, L.; WHITEHEAD, S.; BARRELL, B. G.; MASKELL, D. J. Comparative analysis of the genome sequences of Bordetella pertussis, Bordetella parapertussis and Bordetella bronchiseptica. Nature Genetics, v. 35, n.1, p. 32-40, 2003.

PEREIRA, G. A. Boletim Informativo do Diagnóstico Laboratorial de Coqueluche. Brasil, 2010.

PILIONE, M. R.; HARVILL, E. T. The Bordetella bronchiseptica type III secretion system inhibits gamma interferon production that is required for efficient antibody-mediated bacterial clearance. Infect Immun., v. 74, n. 2, p. 1043-1049, 2006.

PRESKY, D. H.; YANG, H.; MINETTI, L. J.; CHUA, A. O.; NABAVI, N.; WU, C. Y.; GATELY, M. K.; GUBLER, U. A functional interleukin 12 receptor complex is composed of two betatype cytokine receptor subunits. Proc. Natl. Acad. Sci. U S A., v. 93, p. 1400214007, 1996.

PRESTON, A.; PARKHILL, J.; MASKELL, D. J. The Bordetellae: lessons from genomics. Nat. Rev. Microbiol., v. 2, p. 379-390, 2004. 
PRESTON, A.; PETERSEN, B. O.; DUUS, J.; KUBLER-KIELB, J.; BEN-MENACHEM, G.; LI, .; VINOGRADOV, E. Complete Structures of Bordetella bronchiseptica and Bordetella parapertussis Lipopolysaccharides*. The Journal of Biological Chemistry, v. 281, n. 26, p. 18135-18144, 2006.

REISSINGER, A.; SKINNER, J. A.; YUK, M. H. Downregulation of mitogen-activated protein kinases by the Bordetella bronchiseptica Type III secretion system leads to attenuated nonclassical macrophage activation. Infect Immun., v. 73, n. 1, p. 308-316, 2005.

RAW, I.; HIGASHI, H. G. Auto-suficiência e inovação na produção de vacinas e saúde pública. Estudos Avançados, v. 22, n. 64, p. 155-170, 2008.

RODRIGUEZ, M. E.; HELLWIG, S. M.; HOZBOR, D. F.; LEUSEN, J.; VAN DER POL, W. L.; VAN DE WINKEL, J. G. Fc receptor-mediated immunity against Bordetella pertussis. J. Immunol., v. 67, n. 11, p. 6545-6551, 2001.

ROMANI, L.; PUCCETTI, P.; BISTONI, F. Interleukin-12 in Infectious Diseases. Clin. Microb. Rev., v. 10, n. 4, p. 611-636, 1997.

ROSETTI, A. S. Bordetella pertussis: participação da arginase, TGF- $\beta$ e TLR-4 no controle da síntese de óxido nítrico em macrófagos derivados de medula óssea murina. 2009. 98 f. Dissertação (Mestrado em Biotecnologia) - Instituto de Ciências Biomédicas, Universidade de São Paulo, São Paulo, 2013.

ROSS, P. J.; LAVELLE, E. C.; MILLS, K. H.; BOYD, A. P. Adenylate cyclase toxin from Bordetella pertussis synergizes with lipopolysaccharide to promote innate interleukin-10 production and enhances the induction of Th2 and regulatory T cells. Infect. Immun., v. 72, p. 1568-1579, 2004.

ROUX, P. P.; BLENIS, J. ERK and p38 MAPK-Activated Protein Kinases: a Family of Protein Kinases with Diverse Biological Functions. Microbiology and Molecular Biology Reviews, v. 68, n. 2, p. 320-344, 2004.

RUSE, M.; KNAUS, U. G. New players in TLR-mediated innate immunity: PI3K and small Rho GTPases. Immunol Res., v. 34, n. 1, p. 33-48, 2006.

SANOFI. Sanofi Pasteur lança a vacina Adacel Quadra para evitar que adolescentes e adultos transmitam coqueluche aos bebês. São Paulo, sept 2011.

SCHOENHAUT, D. S.; CHUA, A. O.; WOLITZKY, A. G.; QUINN, P. M.; DWYER, C. M.; McCOMAS, W.; FAMILlETTI, P. C.; GATELY, M. K.; GUBBER, U. Cloning and expression of murine IL-12. J. Immunol., v. 148, p. 3433-3440, 1992.

SCHRODER, K.; HERTZOG, P. J.; RAVASI, T.; HUME, D. A. Interferon-gamma: an overview of signals, mechanisms and functions. J. Leukoc. Biol., v. 75, n. 2, p. 163-189, 2004.

SISTEMA DE INFORMAÇÃO DE AGRAVOS DE NOTIFICAÇÃO (SINAN). Disponível em: <http://dtr2004.saude.gov.br/sinanweb/tabnet/dh?sinannet/coqueluche/bases/coquebmet. def>. Acesso em: 16 abr. 2013. 
SMITH, A. M.; GUZMÁN, C. A.; WALKER, M. J. The virulence factors of Bordetella pertussis: a matter of control. FEMS Microbiology Reviews, v. 25, p. 309-333, 2001.

SNIJDERS, A.; HILKENS, C. M. U.; VAN DER POUW KRAAN, T. C. T. M.; ENGEL, M.; AAEDEN, L. A; KAPSENBERG, M. L. Regulation of bioactive IL-12 production in lipopolysaccharide-stimulated human monocytes is determined by the expression of the p35 subunit. J. Immunol., v. 156, p. 1207-1212, 1996.

SPENSIERI, F.; FEDELE, G.; FAZIO, C.; NASSO, M.; STEFANELLI, P.; MASTRANTONIO, P.; AUSIELLO, C.M. Bordetella pertussis Inhibition of Interleukin-12 (IL-12) p70 in Human Monocyte-Derived Dendritic Cells Blocks IL-12 p35 throught Adenylate Cyclase Toxin- Dependent Cyclic AMP Induction. Infection and Immunity, v. 74, n. 5, p. 2831-2838, 2006.

STEED, L. L.; AKPORIAYE, E. T.; FRIEDMAN, R. L. Bordetella pertussis Induces Respiratory Burst Activity in Human Polymorphonuclear Leukocytes. Infection and Immunity, v. 50, n. 5, p. 2101-2105, 1992.

SURESH, A.; SODHI, A Production of interleukin-1 and tumor necrosis factor by bone marrow-derived macrophages: effect of cisplatin and lipopolysaccharide. Immunol. Lett., v. 30, n. 1, p. 93-100, 1991.

TAKEDA, K.; AKIRA, S. TLR signaling pathways. Seminars Immunol., v. 16, p. 3-9, 2004.

TANG, Y-W.; HOPKINS, M. K.; KOLBERT, C. P.; HARTLEY, P. A.; SEVERANCE, P. J.; PERSING, D. H. Bordetella holmesii-Like Organisms Associated with Septicemia, Endocarditis, and Respiratory Failure. Clinical Infectious Diseases, v. 26, p. 389-92, 1998.

TAKEUCHI, O.; AKIRA, S. Pattern recognition receptors and inflammation. Cell, v. 140, n. 6, p. 805-820, 2010.

TRIPATHI, P.; TRIPATHI, P.; KASHYAP, L.; SINGH V. The role of nitric oxide in inflammatory reactions. FEMS Immunol. Med. Microbiol., v. 51, p. 443-452, 2007.

TOZZI, A. E.; CELENTANO, L. P.; ATTI, M. L. C. D.; SALMASO, S. Diagnosis and management of pertussis. Canadian Medical Association or its licensors, v. 172, n. 4, p. 509-515, 2005.

TRABULSI, L. R.; ALTERTHUM, F. Microbiologia. 4. ed. São Paulo: Atheneu, 2005. 718 p.

TRINCHIERI, G. Inerleukine-12 a proinflamatory cytokine with immunoregulatory functions that bridge innate resistance and antigen-specific adaptative immunity. Ann. Rev.Immunol., v. 13, p. 251-276, 1995.

TRINCHIERI, G.; GEROSA, F. Immunoregulation by interleukin-1 2. J. Leukoc.Biol., v. 59, p. 505-511, 1996. 
TRINCHIERI, G. Interleukin-12 and the regulation of innate resistance and adaptive immunity. Nat. Rev. Immunol., v. 3, p. 133-146, 2003.

TRINCHIERI, G.; SHER, A. Cooperation of Toll-like receptor signals in innate immune defence. Nat Rev Immunol., v. 7, n. 3, p. 179-190, 2007.

VALLEDOR, A. F.; BORRA'S, F. E.; CULLELL-YOUNG, M.; CELADA, A.Transcription factors that regulate monocyte/macrophage differentiation. J. Leukoc. Biol., v. 63, p. 405417, 1998.

VANDAMME, P.; HOMMEZ, J.; VANCANNEVT, M.; MONSIEURS, M.; HOSTE, B.; COOKSON, B.; WIRSING VON KÖNIG, C. H.; KERSTERS, K.; BLACKALL, P. J. Bordetella hinzii sp. nov., Isolated from Poultry and Humans. Int. J. Syst. Bacteriol., v. 5, n. 1, p. 37-45, 1995.

VANDAMME, P.; HEYNDRICKX, M.; VANCANNEYT, M.; HOSTE, B.; DE VOS, P.; FALSEN, E.; KERSTERS, K.; HINZ, K. H. Bordetella trematum sp. nov., Isolated from Wounds and Ear Infections in Humans, and Reassessment of Alcaligenes denitrificans Ruger and Tan 1983. Int. J. Syst. Bacteriol., v. 46, n. 4, p. 849-858, 1996.

VAN DER ARK, A. A.; HOZBOR, D. F.; BOOG, C. J.; METZ, B.; VAN DEN DOBBELSTEEN, G. P.; VAN ELS, C. A. Resurgence of pertussis calls for re-evaluation of pertussis animal models. Expert Rev. Vaccines, v. 11, n. 9, p. 1121-37, 2012.

VAN DER ZEE, A.; MOOI, F.; VAN EMBDEN, J.; MUSSER, J. Molecular evolution and host adaptation of Bordetella spp.: phylogenetic analysis using multilocus enzyme electrophoresis and typing with three insertion sequences. J Bacteriol., v. 179, n. 21, p. 66096617, 1997.

VANHAESEBROECK, B.; LEEVERS， S. J.; AHMADI， K.; TIMMS， J.; KATSO, R.; DRISCOLL， P. C.; WOSCHOLSKI， R.; PARKER， P. J.; WATERFIELD， M. D. Synthesis and function of 3-phosphorylated inositol lipids. Annu. Rev. Biochem., v. 70, p. 535-602, 2001.

VECCHIO, M. D.; BAJETTA, E.; CANOVA, S.; LOTZE, M.; WESA, A.; PARMIANI, G.; ANICHINI, A. Interlekin-12: Biological Properties and Clinical Application. Clin Cancer Res., v. 13, n. 16, p. 4677-4685, 2007.

VERSTEEGH, F G. A.; SCHELLEKENSB, A. F.; ROORDD, J. J. Pertussis: a concise historical review including diagnosis, incidence, clinical manifestations and therole of treatment and vaccination in management. Rev. Medical Microbiology, v. 16, p. 79-89, 2005 .

VON WINTZINGERODE, F.; SCHATTKE, A.; SIDDIQUI, R. A.; RÖSICK, U.; GÖBEL, U. B.; GROSS, R. Bordetella petrii sp. nov., isolated from an anaerobic bioreactor, and emended description of the genus Bordetella. International Journal of Systematic and Evolutionary Microbiology, v. 51, p. 1257-1265, 2001.

WANG, Z. Y.; YANG, D.; CHEN, Q.; LEIFER, C. A.; SEGAL, D. M.; SU, S. B.; CASPI, R. R.; HOWARD, Z. O.; OPPENHEIM, J. J. Induction of dendritic cell maturation by pertussis 
toxin and its B subunit differentially initiate Toll-like receptor 4-dependent signal transduction pathways. Exp Hematol., v. 34, p. 1115-1124, 2006.

WATANABE, M.; NAGAI, M. Role of systemic and mucosal immune responses in reciprocal protection against Bordetella pertussis and Bordetella parapertussis in a murine model of respiratory infection. Infect Immun., v. 71, n. 2, p. 733-738, 2003.

WATFORD, W. T.; MORIGUCHI, M.; MORINOBU, A.; O'SHEA, J. J. The biology of IL12: coordinating innate and adaptive immune responses. Cytokine Growth Factor Rev, v. 14, n. 5, p. 361-368, 2003.

WING, C. Patogenesis, colonisation and LPS endotoxin of Bordetella pertussis. Disponível em: <http://www.uea.ac.uk/menu/acaddepts/cap/carbohydrate/CCCPeople/Corin/welcome. htm>. Acesso em: 14 ago. 2011.

WOOD, N.; MCINTYRE, P. Pertussis: review of epidemiology, diagnosis, management and prevention. Pediatric Respiratory Reviews, v. 9, p. 201-212, 2008.

WOLFE, D. N.; KIRIMANJESWARA, G. S.; HARVILL, E. T. Clearance of Bordetella parapertussis from the Lower Respiratory Tract Requires Humoral and Cellular Immunity. Infection and Immunity, v. 73, n.10, p. 6508-6513, 2005.

WOLFE, D. N.; KIRIMANJESWARA, G. S.; GOEBEL, E. M.; HARVILL, E. T. Comparative role of immunoglobulin A in protective immunity against the Bordetellae. Infect Immun., v. 75, n. 9, p. 4416-4422, 2007.

WOLFE, D. N.; GOEBEL, E. M.; BJORNSTAD, O. N.; RESTIF, O.; HARVILL, E. T. The $\mathrm{O}$ antigen enables Bordetella parapertussis to avoid Bordetella pertussis-induced immunity. Infect. Immun., v. 75, p. 4972-4979, 2007.

WOLFE, D. N.; MANN, P. B.; BUBOLTZ, A. M.; HARVILL, E. T. Delayed Role of Tumor Necrosis Factor- $\alpha$ in Overcoming the Effects of Pertussis Toxin. The Journal of Infectious Diseases, v. 196, p. 1228-1236, 2007.

WOLFE, D. N.; BUBOLTZ, A. M.; HARVILL, E. T. Inefficient Toll-like receptor4 stimulation enables Bordetella parapertussis to avoid host immunity. PLoS One, v. 4, n. 1, p. e4280, 2009.

WOLFE, D. N.; KARANIKAS, A. T.; HESTER, S. E.; KENNETT, M. J.; HARVILL, E. T. IL-10 induction by Bordetella parapertussis limits a protective IFN-gamma response. J. Immunol., v. 184, n. 3, p. 1392-1400, 2010.

WOOLFREY, F. B.; MOODY, J. A. Human infections associated with Bordetella bronchiseptica. Clin. Microbiol. Rev., v. 4, p. 234-255, 1991.

YUK, M. H.; HARVILL, E. T.; COTTER, P. A.; MILLER, J. F. Modulation of host immune responses, induction of apoptosis and inhibition of NF-kappaB activation by the Bordetella type III secretion system. Mol. Microbiol., v. 35, p. 991-1004, 2000. 
ZAKHAROVA, M.; ZIEGLER, H. K. Paradoxial Anti-Inflammatory Actions of TNF$\alpha$ Inhibition of IL-12 and IL-23 via TNF receptor 1 in Macrophages and Dendritic Cells. The Journal of Immunology, v. 175, p. 5024-5033, 2005.

ZANONI, I.; GRANUCCI, F. Dendritic Cells and Macrophages: Same Receptors but Different Functions. Current Immunology Reviews, v. 5, p. 311-325, 2009.

ZHANG, Y.; DONG, C. MAP Kinases in Immune Responses. Cellular \& Molecular Immunology Review, v. 2, n. 1, p. 20-27, 2005.

ZHANG, S.; WANG, Q. Factors determining the formation and release of bioactive IL-12: Regulatory mechanisms for IL-12p70 synthesis and inhibition. Biochemical and Biophysical Research Communications, v. 372, p. 509-515, 2008.

ZHANG, X.; GOEBEL, E. M.; RODRIGUEZ, M. E.; PRESTON, A.; HARVILL, E. T. The $\mathrm{O}$ antigen is a critical antigen for the development of a protective immune response to Bordetella parapertussis. Infect Immun., v. 77, n. 11, p. 5050-5058, 2009. 